Illinois State University

ISU ReD: Research and eData

Theses and Dissertations

7-7-2021

\title{
The Revolution's Abolitionist Promise: America's Interdiction of the Atlantic Slave Trade and the Long Road to Emancipation, 1820-1862
}

Matthew H. Nalefski

Illinois State University, matthew.nalefski@gmail.com

Follow this and additional works at: https://ir.library.illinoisstate.edu/etd

\section{Recommended Citation}

Nalefski, Matthew H., "The Revolution's Abolitionist Promise: America's Interdiction of the Atlantic Slave Trade and the Long Road to Emancipation, 1820-1862" (2021). Theses and Dissertations. 1455.

https://ir.library.illinoisstate.edu/etd/1455

This Thesis is brought to you for free and open access by ISU ReD: Research and eData. It has been accepted for inclusion in Theses and Dissertations by an authorized administrator of ISU ReD: Research and eData. For more information, please contact ISUReD@ilstu.edu. 
THE REVOLUTION'S ABOLITIONIST PROMISE: AMERICA'S INTERDICTION OF THE ATLANTIC SLAVE TRADE AND THE LONG ROAD TO EMANCIPATION, 1820-1862

\section{MATTHEW H. NALEFSKI}

\section{Pages}

This thesis will explore the US commitment to the destruction of the international slave trade following its abolition in 1808, studying its impact on US sovereignty, the coming of the Civil War, and abolitionism. Long ignored by historians, the United States' attempts from 1808 to 1862 to abolish the illegal international trade in slaves has the potential to change the historiographical understanding of abolitionism in the antebellum period. Slavery was not eradicated overnight, a fact that we accept unquestioningly; but neither was the international slave trade. The parallel evolution of abolitionism on the one hand combined with diplomatic, legal, and antislavery mechanisms related to the slave trade on the other ultimately created the necessary elements for the institution's eventual abolition altogether. Ignoring attempts to stop the international slave trade has obscured the complexity of abolitionism in the United States. Emphasizing the United States' commitment to slave-trade suppression means to complicate the picture of an entirely acquiescent US government, which served as the slavocracy's puppet, and demonstrates that, in the end, the Revolution's abolitionist promise was fulfilled.

KEYWORDS: Antebellum American history; Atlantic slave trade; slave-trade suppression; abolition; antislavery; antebellum law 
THE REVOLUTION'S ABOLITIONIST PROMISE: AMERICA'S INTERDICTION OF THE ATLANTIC SLAVE TRADE AND THE LONG ROAD TO EMANCIPATION, 1820-1862

MATTHEW H. NALEFSKI

A Thesis Submitted in Partial

Fulfillment of the Requirements for the Degree of

MASTER OF ARTS

Department of History

ILLINOIS STATE UNIVERSITY 
(C) 2021 Matthew H. Nalefski 
THE REVOLUTION'S ABOLITIONIST PROMISE: AMERICA'S INTERDICTION OF THE ATLANTIC SLAVE TRADE AND THE LONG ROAD TO EMANCIPATION, 1820-1862

MATTHEW H. NALEFSKI

COMMITTEE MEMBERS:

Ronald M. Gifford, Co-Chair

Ross A. Kennedy, Co-Chair

Stewart L. Winger 


\section{ACKNOWLEDGMENTS}

I thank the History Department's faculty and staff for their help and support throughout my time in the program. In particular, I thank Dr. John Reda, whose HIS 497 class spawned the basis of this project, and Drs. Ross Kennedy and Stewart Winger for taking the time to serve on my committee and their suggestions and encouragement at each stage of the process. And, to my committee chair Dr. Ron Gifford, I express the utmost gratitude for his constant patience, support, wisdom, and enthusiasm. Without his guiding vision for this project, I might well not have finished it.

To my friends and family, my appreciation for your support cannot be put into words. I was exceptionally lucky to make friends of many of my peers in the program. To Tim, Race, and Reid, in particular, the beers and laughs over these two years offered a much-needed, rejuvenating distraction from the rigors of the classroom. To my mom and dad, I thank you for your endless love, your faith and confidence in me, and for instilling in me a lifelong love of learning; without you, I would not be the man I am today. And, without the constant advice and patient support of Rachel Tomlovich, one of my oldest and closest friends, I confidently say that I would not have made it through the program. I cannot overstate how soothing, how reassuring, her presence has been. As ever, I am in her debt.

I dedicate my thesis to my late aunt, Lee Ann Beane, who passed away while I was in the process of writing. My earliest memories are marked with her kind, loving presence. She was a guide and mentor, a friend and confidante, and the model for a life of compassion and warmth toward others. She was the best aunt a boy could ever have. She will be profoundly missed.

M. H. N. 


\section{CONTENTS}

Page

ACKNOWLEDGMENTS

INTRODUCTION

CHAPTER I: ORIGINS: A DIPLOMATIC DILEMMA 21

CHAPTER II: THE MEANS AND ENDS: FREEDOM INTERNATIONAL? 52

"What Could Be Done with Honest Exertion and an Adequate Force" 59

The Interim: Webster-Ashburton and the Amistad 79

"It Is Truly Dignified and Just, Right and Salutary" $\quad 84$

CHAPTER III: CHARACTER: THE AMERICAN COLONIZATION SOCIETY, ABOLITIONISM, AND “THE GREAT SAFETY VALVE OF THIS UNION!” 102

$\begin{array}{ll}\text { CONCLUSION } & 123\end{array}$

$\begin{array}{ll}\text { BIBLIOGRAPHY } & 129\end{array}$

$\begin{array}{ll}\text { INTRODUCTION TO THE APPENDICES } & 147\end{array}$

APPENDIX A: ALL SLAVE-TRADE CASES EXAMINED 149

APPENDIX B: US NAVAL SEIZURES 153

APPENDIX C: US NAVAL COMMITMENT TO SLAVE-TRADE SUPPRESSION 154

APPENDIX D: ROYAL NAVY COMMITMENT TO SLAVE-TRADE

SUPPRESSION (1837) 162 


\section{INTRODUCTION}

On August 29, 1839, Lieutenant Thomas R. Gedney filed his libel with the United States District Court for Connecticut. The libel, the traditional pleading by which individuals petitioned for salvage rights in admiralty cases, alleged that he and the crew of his ship encountered a "strange \& suspicious" schooner anchored off Culloden Point, Long Island, three days prior. Sending his first officer to investigate with a boarding party, Gedney discovered that the schooner, identified as the "Armistad," was a slave ship. Now in Connecticut, Gedney hoped that prize money awaited him. ${ }^{1}$

Gedney could not have known that the Amistad, even then, was a strange slave ship. Gedney and the crew of the Washington "found said Schooner was manned by forty five negroes" and that two Spanish "Gentlemen," Cubans Pedro Montes and Jose Ruiz, were seemingly their captives. The US sailors rounded up the Africans and confined them below, freeing the Spaniards from their oppressive confinement, and the Washington headed to New London, Connecticut, with the slave ship in tow. After reaching port, Gedney carefully wrote out the circumstances by which, two months earlier, the Africans "rose upon" the crew, murdered two men, including the captain, and took possession of the vessel. This report heavily relied on the allegations of Montes and Ruiz. But, first, he made a point to enumerate the cargo. Among the glassware and hardware, skins and fabrics, olive oils and beef were fifty-four slaves-fiftyone men and three women. Altogether, the Africans, Gedney noted, were worth $\$ 25,000$. That was in addition to the $\$ 40,000$ that he estimated for the rest of the cargo. Gedney asked that the slave ship be forfeited, but not without monetary reward. This was the mechanical, often

\footnotetext{
1 "Libel of Thomas R. Gedney," August 29, 1839, National Archives Identifier 2787899, Thomas R. Gedney v. Schooner Amistad, Case Files 1790 - 1911, Records of the District Courts of the United States, 1685 - 2009, Record Group 21, National Archives, Waltham, MA, https://www.docsteach.org/documents/document/gedney-libel.
} 
unfeeling process of slave-trade suppression in the United States. As the result of the apparently callous nature of slave-trade prosecutions, historians have found it difficult to characterize them as the product of antislavery or part of the abolition movement. Nevertheless, the slave trade, or the means by which it was suppressed, represents a distinct convergence of the historiography of abolitionism with those of antebellum US diplomacy and the coming of the Civil War, which cannot be ignored. ${ }^{2}$

The story of the Amistad rebellion has become well known since its revived study in the late 1960s. But historians have disagreed on how the case should be viewed. David Brion Davis and Howard Jones have argued that the case showed the US judiciary's antislavery potential, ${ }^{3}$ whereas Marcus Rediker has dismissed any suggestion of a victorious legal system. For him, the slaves were the true "heroes" of the story. Exercising individual agency, they worked together and removed themselves from bondage. Imprisoned as their case worked its way to the Supreme Court, they further navigated between different interested groups, from abolitionists to proslavery advocates, to reassert the freedom that they seized along the coast of Cuba. ${ }^{4}$ Undoubtedly to Rediker's chagrin, Steven Spielberg's 1997 titular film has, however, cemented a triumphalist narrative for the case in popular imagination. ${ }^{5}$ In part, John Quincy Adams' passionate oral argument before the Supreme Court reinforced this interpretation. Over

\footnotetext{
2 "Libel of Thomas R. Gedney," August 29, 1839, National Archives Identifier 2787899, Thomas R. Gedney v. Schooner Amistad, Case Files 1790-1911, Records of the District Courts of the United States, 1685-2009, Record Group 21, National Archives, Waltham, MA, https://www.docsteach.org/documents/document/gedney-libel. Marcus Rediker writes that there were only fifty-three enslaved Africans aboard the Amistad, forty-nine men and four children. Marcus Rediker, The Amistad Rebellion: An Atlantic Odyssey of Slavery and Freedom (New York: Penguin Books, 2012), 1.

${ }^{3}$ David Brion Davis, Inhuman Bondage: The Rise and Fall of Slavery in the New World (New York: Oxford Univ. Press, 2006), 26; Howard Jones, Mutiny on the Amistad: The Saga of a Slave Revolt and Its Impact on American Abolition, Law, and Diplomacy (New York: Oxford Univ. Press, 1987), 218-219.

${ }^{4}$ Rediker, The Amistad Rebellion, 4-8. It should be noted that, despite this disagreement, Rediker praises Jones' work as the "pinnacle of scholarship." Rediker, The Amistad Rebellion, 261 n3.

${ }^{5}$ Rediker, The Amistad Rebellion, 4-5.
} 
the course of two days, Adams constructed a logical, yet emotional appeal that seemed to combine the moral calls of abolitionism and the worldly realities of slavery's place in the law without grappling too intensively with specific legislation. He emphasized the humanity of those same fifty-four enslaved Africans whom Gedney so matter-of-factly enumerated in his libel; and he framed their freedom as an undeniable consequence of nature. Higher law would be rendered actuality through the United States' highest court. ${ }^{6}$

Setting aside Adams' rhetoric, however, the reality — the story of the process by which those slaves were freed - reveals itself to have been one of anticlimactic routine. The Amistad case bridged two eras of abolitionism. As antislavery moved away from gradualism to immediatism, the case shows that even these new abolitionists were thinking in traditional legalistic ways. In its application of the moral appeals of radical abolitionism to slave-ship seizures, the case of the Amistad Africans was unusual. But its roots were in the often practical, rarely dramatic process of antebellum slave-trade suppression. This was a process that relied heavily on the forfeiture of slave traders' ships and property, rather than trials of the slave traders themselves. Prosecutors knew that slave traders were rarely convicted, and, when they were, those convictions could not yet be based on the most serious of crimes: the capital crime of piracy. The process of ship seizures and forfeitures played out in federal courts throughout the

\footnotetext{
${ }^{6}$ An example of Adams' rhetorical fusion of these pieces can be found on pages eight and nine of the copy of his argument published by S. W. Benedict in 1841: "One of Judges who presided in some of the preceding trials, is said to have called this an anomalous case. It is indeed anomalous, and I know of no law, but one which I am not at liberty to argue before this Court, no law, statute or constitution, no code, no treaty, applicable to the proceedings of the Executive or the Judiciary, except that law, (pointing to the copy of the Declaration of Independence, hanging against one of the pillars of the court-room, ) that law, two copies of which are ever before the eyes of your Honors. I know of no other law that reaches the case of my clients, but the law of Nature and of Nature's God on which our fathers placed our own national existence. The circumstances are so peculiar, that no code or treaty has provided for such a case. That law, in its application to my clients, I trust will be the law on which the case will be decided by this court." John Quincy Adams, Argument of John Quincy Adams Before the Supreme Court of the United States, in the Case of the United States, Appellants, vs. Cinque, and Others, Africans, Captured in the Schooner Amistad [...] (New York: S. W. Benedict, 1841), 8-9, https://lccn.loc.gov/11027427.
} 
antebellum period, as the United States slowly worked its way toward the slave trade's destruction. ${ }^{7}$ Steadily accumulating precedent, the federal government, by the Civil War's eve, had primed the judicial system for the trial, conviction, and execution of a slave trader. Despite its peculiarity, the Amistad case was among these cases that built toward the slave trade's total suppression. It highlighted, albeit sensationally, the legal mechanisms through which antislavery had been enacted for two decades. While the US judicial system might not have been, in Rediker's words, the story's "hero," it was certainly the tool by which the nation would be set on the path to emancipation.

Historians have long debated the sincerity with which the United States worked to suppress the international slave trade. Having led the world with its constitutional promise to ban the importation of slaves, which Congress legislated upon in $1808,{ }^{8}$ the United States' commitment to slave-trade suppression appeared hollow within the first years of the law's effect. The 1808 Act Prohibiting the Importation of Slaves, in fact, marked a lull in political antislavery as US foreign policy came to be dominated by British impressment, which reached crisis proportions with the War of $1812,{ }^{9}$ foreshadowing, in the commonly accepted narrative, traditional abolition's eventual demise. While it is evident that US citizens engaged in the African slave trade and that the importation of slaves to the United States continued after 1808,

\footnotetext{
${ }^{7}$ For US laws related to the slave trade, see Appendix A.

816 Annals of Cong. 231 (1806), https://hdl.handle.net/2027/uc1.\$c227014; Slave Trade Prohibition Act of March 2, 1807, ch. 22, 2 Stat. 205, https://avalon.law.yale.edu/19th_century/s1004.asp; Paul Finkelman, Slavery in the Courtroom: An Annotated Bibliography of American Cases (1985; Clark, NJ: Lawbook Exchange, 2020), 212. ${ }^{9}$ Bemis, A Diplomatic History of the United States, $3^{\text {rd }}$ ed. (1936; New York: Henry Holt, 1950), 208; Scott A. Silverstone, Divided Union: The Politics of War in the Early American Republic (Ithaca, NY: Cornell Univ. Press, 2004), 19; Gordon S. Wood, Empire of Liberty, 622-630, 698-700; George C. Herring, From Colony to Superpower: U.S. Foreign Relations Since 1776 (New York: Oxford Univ. Press, 2008), 116. For American fears of their antirepublican neighbor Canada, see also Reginald Horsman, "On to Canada: Manifest Destiny and United States Strategy in the War of 1812," Michigan Historical Review 13, no. 2 (Fall 1987): 4. For the importance of neutral trading rights in the Jeffersonian republican mind, see James R. Sofka, "The Jeffersonian Idea of National Security: Commerce, the Atlantic Balance of Power, and the Barbary War, 1786-1806," Diplomatic History 21, no. 4 (Fall 1997): 520.
} 
without significant interference from the US government, most historians have assumed that the international slave trade ceased to be an important issue and instead have focused on the internal slave trade. Nevertheless, estimates range wildly over the extent of the trade conducted between 1808 and 1865 , with historians asserting that anywhere from 50,000 to 786,500 enslaved persons were illegally imported to the United States over the period. ${ }^{10}$ In a recent study, published last year, John Harris has argued that the trade saw a significant increase after 1850, with as many as 198,000 Africans trafficked between 1853 and $1867 .{ }^{11}$ At a time when the average day laborer made $\$ 1.18$ daily and an average Southern family brought home less than $\$ 100$ in an entire year, the illicit sale of an enslaved African could fetch from $\$ 400$ to $\$ 1,500$ - in one transaction. The trade's illegal conduct was repulsively profitable. ${ }^{12}$ In the literature, whether the importation trade continued after 1808 is indisputable. While the trade's scale and the manner by which it was conducted are matters of debate, they are not the focus of this study. Rather, this thesis intends to examine the response to the continued illicit trade of African slaves and the diplomatic, legal, and sociopolitical mechanisms that abolitionists put into place before the Civil War. It ultimately seeks to answer how the destruction of the slave trade fits into our understanding of emancipation throughout the antebellum period.

In the United States, the assault against the Atlantic slave trade represented the first step toward fulfilling Revolutionary republicanism's hope to set slavery on the course toward

\footnotetext{
${ }^{10}$ Ernest Obadele-Starks, Freebooters and Smugglers: The Foreign Slave Trade in the United States After 1808 (Fayetteville: Univ. of Arkansas Press, 2007), 9-10; Don E. Fehrenbacher, The Slaveholding Republic: An Account of the United States Government's Relations to Slavery, ed. Ward M. McAfee (New York: Oxford Univ. Press, 2001), 149, 150. Fehrenbacher provided the low end of this range and cited Du Bois' figure of 250,000, dismissing it as too high. The version of Du Bois' Suppression of the African Slave-Trade available to the author does not contain such an estimate. While almost absurdly high, Obadele-Starks provided the top end of this range, extrapolating from Philip D. Curtin's estimates in: Philip D. Curtin, The Atlantic Slave Trade: A Census (Madison: Univ. of Wisconsin Press, 1969).

${ }^{11}$ John Harris, The Last Slave Ships: New York and the End of the Middle Passage (New Haven, CT: Yale Univ. Press, 2020), 6.

${ }^{12}$ Obadele-Starks, Freebooters and Smugglers, 3-14.
} 
eventual extinction. Undoubtedly, the contradiction between the United States' founding principles and the presence of domestic slavery weighed heavily on the minds of antislavery advocates in the years after the Revolution. ${ }^{13}$ These early advocates, driven by Revolutionary republican sentiments and religious beliefs, ${ }^{14}$ established "abolitionist" societies across the North and pushed local legislatures to enact laws leading to gradual emancipation. ${ }^{15}$ Their efforts were not limited, however, within their respective states. Rather, these abolitionist societies also emphasized the closure of the foreign slave trade as a tool to fulfilling the Revolution's principles; they saw abroad a crucial answer to the problem of slavery and a potential first, nationwide step toward emancipation. ${ }^{16}$ By cutting off the supply of enslaved Africans from their source abroad and domestically limiting the institution's spread, slavery would be, the Revolution-era antislavery advocate believed, choked over time to its demise. Its importance to the continued growth of the United States' enslaved population was therefore paramount and demanded the first meaningful salvo of antislavery in the young republic. Following this thinking, the Framers imbedded in the Constitution a promise to forbid the international slave

\footnotetext{
${ }^{13}$ See David Cooper, A Serious Address to the Rulers of America, on the Inconsistency of Their Conduct Respecting Slavery (London, 1783), ed. Rebecca Miller, in Early American Abolitionists: A Collection of Anti-Slavery Writings, 1760 - 1820, ed. James G. Basker, Justine Ahlstrom, Kathleen Barry, Siobhan Phinney, Nicole Seary, Sandra Trenholm, and Thorin Tritter (New York: Gilder Lehrman Institute of American History, 2005), 61.

${ }^{14}$ Filled with scriptural justification and appeals to morality, Cooper's writing recalls the antislavery arguments of pre-Revolution America. Along this line, it draws a distinction between the cruelties of domestic slavery and the Atlantic slave trade. Much like the writings of prominent pre-Revolution abolitionist Anthony Benezet, Cooper distinguishes the traffic of enslaved Africans across the Atlantic as uniquely vile. For both examples of the emphasis on Christian ethics and, in particular, the slave trade, see Anthony Benezet, Observations on the Inslaving, Importing and Purchasing of Negroes (Germantown, PA, 1760), ed. Thomas Wolf, in Basker et al., Early American Abolitionists, 9-15; Benezet, Notes on the Slave Trade (n.p., 1781), ed. Thomas Wolf, in Basker et al., Early American Abolitionists, 24-28. A contemporary of Benezet, Cooper had written against slavery and the slave trade as early as 1772. Cooper, A Mite Cast into the Treasury: Or, Observations on Slave-Keeping (Philadelphia, 1772), ed. Kristin DeBusk, in Basker et al., Early American Abolitionists, 37-49. Cooper even goes so far as to call on anyone who approves of the trade to "cease to boast the Christian name." Cooper, A Serious Address, 66.

${ }^{15}$ The Pennsylvania Abolition Society, begun in 1775, and its state's 1780 Act for the Gradual Abolition of Slavery are the classic examples of this shift from simple antislavery to abolitionism. See The Constitution of the Pennsylvania Society, for Promoting the Abolition of Slavery (Philadelphia, 1787), ed. Sam Rosenfeld, in Basker et al., Early American Abolitionists, 87-91, 93-98.

${ }^{16}$ Jonathan Edwards, The Injustice and Impolicy of the Slave Trade and of the Slavery of the Africans [...] A Sermon ([New Haven, CT?], 1791), ed. Sarah Gamertsfelder, in Basker et al., Early American Abolitionists, 161.
} 
trade after twenty years. And, in 1808, when the Act Prohibiting the Importation of Slaves went into effect, the United States codified this commitment, seemingly representing the end to the first part of the Founders' plan to rid their republic of slavery.

Understanding the complexities of foreign policy during the antebellum period, historians have taken for granted that the United States was involved in the suppression of the slave trade. While it has accepted that suppression of the international slave trade was a US diplomatic commitment, the historiography has dismissed the sincerity with which the young republic pursued the policy. ${ }^{17}$ The United States had been founded and bound in union through a constitution that protected slavery's existence - and that, arguably, led to the emergence of a domestic "Slave Power." That the republic was pursuing slavers on the high seas has been seen as the reflection of international obligations rather than any genuine desire for slavery's destruction. But the seizure and adjudication of slave ships throughout the period reflected the Founders' aim to eradicate slavery gradually and was part of a larger abolitionist strategy that, using the legalistic methods of traditional antislavery, built toward emancipation. The historiography has therefore failed to see the significant degree to which slave-trade suppression was a matter of federal policy, and it has accepted without necessary interrogation that the slave trade continued after the United States' 1808 ban. Weighed down by historiographical preconceptions, historians have naturally approached the subject without the inquisitiveness of a

\footnotetext{
${ }^{17}$ W. E. B. Du Bois, The Suppression of the African Slave-Trade (1896; New York: Oxford Univ. Press, 2007), 97; Obadele-Starks, Freebooters and Smugglers, 3-14; Daniel Walker Howe, What Hath God Wrought: The Transformation of America, 1815-1848 (New York: Oxford Univ. Press, 2007), 312, 678; Matthew Karp, This Vast Southern Empire: Slaveholders at the Helm of American Foreign Policy (Cambridge, MA: Harvard Univ. Press, 2016), 3-5, 52-57. As early as 1896, W. E. B. Du Bois declared that the nation had stymied any serious international agreement simply because it wanted to avoid exposing its own "criminal negligence." Looking domestically, Ernest Obadele-Starks, in 2007, described a culture of conspiracy deeply imbedded in the South, which facilitated the illegal trade's continued conduct. Analyzing US foreign policy during the antebellum period, Daniel Walker Howe and Matthew Karp have maintained that Southern control of policymaking steered the United States from international efforts at slave-trade suppression.
} 
stranger and, as a result, have overlooked a crucial line of inquiry. They have neglected to consider the simple question: what happened to the slave trade?

At issue is the US government's relationship to slavery. For, in the historiography of the early republic and antebellum periods, two distinct portraits of this relationship have emerged. Whereas some historians have maintained that the antislavery of the nation's founding played a crucial role in US policymaking up to the Civil War, others have contended that, regardless of the republic's principled origins, the US government was, for all intents and purposes, the representative of the Slave Power. The works of two historians, in particular-James Oakes and Don E. Fehrenbacher—best demonstrate this historiographical debate.

In his 2013 book, Freedom National, Oakes told of the decades-long effort to build a legal framework for the eventual political abolition of slavery. He argued that, over the course of the antebellum period, antislavery advocates constructed and built on the legal argument that freedom was a national principle and that individual states were the only governments that could regulate slavery. This "freedom principle" had its roots in the English decision of Somerset $v$. Stewart in 1772, which held that there could be, under common law, no "property in man," for freedom was an individual's natural condition. In the years leading up to the Civil War, abolitionist-minded attorneys consistently applied it to slavery within the United States. As the federal government could not forbid states from allowing slavery, these lawyers formulated that only by surrounding slave states with free territories, thereby pressuring emancipation, or enacting the well-precedented tool of military emancipation, as a means of quelling civil unrest, could slavery be extinguished. And it was, according to Oakes, this constitutional argument and the Republican party's adoption of that argument that spurred the Southern states to secede. Going against suggestions that the Lincoln administration slowly moved toward emancipation as 
an exigency of war, Oakes contended that the Republicans entered the White House in 1861 with emancipation in mind. It was only as the war progressed that Lincoln and his administration pursued the policy with greater vengeance. In Oakes' view, therefore, it was the purposely abolitionist character of the federal government that brought about emancipation. ${ }^{18}$

Critically, Oakes' work reconsidered the nature of abolitionist politics. He demonstrated that the legal theory on which abolitionist court cases spanning the antebellum period were based was the result of a carefully planned, logical attack on slavery's existence. It thus represented the continuity of a more traditional, legalistic abolitionism that predated immediatism. Anticipating and responding to the arguments of proslavery constitutionalists, the goal of these advocatesSalmon Chase, Joshua Giddings, and Charles Sumner, to name a few-was to limit slavery to the point of extinction. Slowly, this gradualist constitutional argument would reduce the prominence of slave states in the federal government and set the nation on the path to total emancipation. ${ }^{19}$ Although it recalled the measured approach of pre-Garrisonian abolitionism, this was, as Oakes wrote, "the platform on which Abraham Lincoln ran for president, and on which he won."20 The freedom principle also applied internationally. Republicans believed that, by “denationalizing” slavery, ${ }^{21}$ the federal government would become unentangled by the Slave Power's influence and move toward protection of freedom abroad. As Oakes wrote, "Wherever the federal government was sovereign — on the high seas, in the western territories, and in the nation's capital—slavery would be abolished by the government." ${ }^{22}$ It was, accordingly, a federal obligation to suppress the international slave trade. As Oakes illustrated, Republicans

\footnotetext{
${ }^{18}$ James Oakes, Freedom National: The Destruction of Slavery in the United States, 1861-1865 (New York: W. W. Norton, 2013), ix-xiii, xix.

${ }^{19}$ Oakes, Freedom National, 1-34.

${ }^{20}$ Oakes, Freedom National, 48.

${ }^{21}$ Oakes, Freedom National, 26.

${ }^{22}$ Oakes, Freedom National, 33.
} 
understood that duty. That Secretary of State William H. Seward moved within the first months of the administration to sign a treaty with Great Britain over the slave trade was, Oakes showed, evidence of this point. ${ }^{23}$ Freedom National therefore depicted an abolitionist-motivated United States situated in a world where proactive defense of human freedom was seen as a necessity.

On its face, the argument that Don E. Fehrenbacher laid out in his posthumously published The Slaveholding Republic (2001) ran parallel to Oakes' Freedom National. Fehrenbacher maintained throughout the work that the "federal consensus" - the notion that slavery was a state concern outside the realm of federal interference-played a significant role in the intersectional dealings over slavery since the republic's founding. Certainly, it was, to Fehrenbacher, within the Constitution's legal and moral purview that the federal government could prevent slavery from spreading westward to the territories. But Fehrenbacher held that, by the Civil War's eruption, the consensus had become the pawn of sectionalism, with each side developing its own diametrically opposed version of the Framers' intentions. While the South unitedly proclaimed the Constitution to be a proslavery document, the North, Fehrenbacher pointed out, varied in its assessments. Garrisonians, in particular, asserted that the Constitution was, in fact, proslavery. Fehrenbacher explained that, although this position was wrong, it was the product of the patently proslavery precedents of federal government action developed since the nation's founding. Fehrenbacher averred that, regardless of the Framers' intentions, the federal government had become a proslavery institution. In those eighty-four years of existence, it had become a "slaveholding republic." 24 It is in this way that he distinguished himself from Oakes. For, rather than emphasizing a constant effort that moved toward emancipation, he stressed the degree to which the federal government prevented that struggle.

\footnotetext{
${ }^{23}$ Oakes, Freedom National, 262-263.

${ }^{24}$ Fehrenbacher, The Slaveholding Republic, 10-13.
} 
Crucially, Fehrenbacher portrayed the Republican party as far from the abolitionist character of Oakes's Freedom National. According to his narrative, pro-abolitionist political forces were overwhelming Abraham Lincoln by the summer of 1862 with calls for uncolonized emancipation. Lincoln was, in Fehrenbacher's view, “often passive, tardy, and at times discouraging of moving in this direction [emancipation] on his own accord." While he was certainly a gradual emancipationist, who, Fehrenbacher explained, believed that "any Union worth preserving had as a prerequisite that slavery should first be restricted and ultimately be eliminated," Lincoln was a pragmatist, a politician who understood the give and take of political dealing. Hostage to radicals, and with a progressively larger number of enslaved African Americans freeing themselves, Lincoln tried to gain control of the issue by adopting a more radical, pro-abolitionist position than he initially intended. "The president," Fehrenbacher wrote, "concluded that to maximize his effectiveness in leading this chaotic mix of conflicting interests he had to move closer to the abolitionist position." 25

Using the United States' inconsistent suppression of the international slave trade, Fehrenbacher extended his proslavery depiction into the earliest days of the republic. Questioning the sincerity of the slave trade laws, he portrayed US slave-trade suppression as periodic and deliberately decentralized, requiring the "initiative" and "cooperation" of elements of all levels of government. ${ }^{26}$ While the early federal efforts to suppress the slave trade were met with resounding support, this sentiment dissipated as the nineteenth century progressed.

Fehrenbacher concluded that "the history of the federal government's relation to the African slave trade begins with impressive legislation but is primarily a study of faulty enforcement." 27

\footnotetext{
${ }^{25}$ Fehrenbacher, The Slaveholding Republic, 312-314.

${ }^{26}$ Fehrenbacher, The Slaveholding Republic, 150-152.

${ }^{27}$ Fehrenbacher, The Slaveholding Republic, 136-137.
} 
While Fehrenbacher underscored that the international slave trade was of minor significance to both the North and South, ${ }^{28}$ he used it to exemplify international perceptions of the United States' as a proslavery state. "Although the nation had been termed 'a house divided against itself' and 'half slave and half free,' in one respect," he wrote, "unity had tended to prevail over duality." Pointing to Southern "hypersensitivity to anything touching slavery" that prevented consistent enforcement of US law, ${ }^{29}$ he argued that the resulting foreign policy was generally proslavery. He concluded that "Whatever it might be as a federal union of sovereign states, the antebellum United States, as a sovereign state itself, was a slaveholding republic. That was the impression given by the national capital. That was the image presented in diplomacy to the rest of the world. And that had become the law of the land by edict of the Supreme Court." ${ }^{30}$ In Fehrenbacher's assessment, the interests of the Slave Power were directly reflected in the policies of the federal government.

Although he implied the construction of and advocacy for "freedom national" extended internationally, Oakes curiously accepted Fehrenbacher's analysis of an overtly proslavery US foreign policy across the period. Prefacing the speed with which Seward entered into negotiations with the British government over slave-trade suppression, Oakes explained that "When in 1860 opponents of slavery looked back over the course of American diplomatic history, they saw an unbroken record of support for slavery." ${ }^{31}$ In his endnote, Oakes wrote that "The actual history of slavery and American foreign policy was more complicated than the abolitionists suggested, primarily because the territorial expansion was popular in the North as well as in the South. Nevertheless, there was an indisputably proslavery bias to American

\footnotetext{
${ }^{28}$ Fehrenbacher, The Slaveholding Republic, 204.

${ }^{29}$ Fehrenbacher, The Slaveholding Republic, 203.

${ }^{30}$ Fehrenbacher, The Slaveholding Republic, 296.

${ }^{31}$ Oakes, Freedom National, 261.
} 
diplomacy." He cited Fehrenbacher as this claim's evidence. ${ }^{32}$ Oakes' quickness to embrace the accepted narrative of antebellum US diplomacy highlights an unexplored aspect of his thesis. Because the focus of Freedom National was domestic emancipation, Oakes did not attempt to test the freedom principle's applicability outside the United States. While he claimed that freedom was international, Oakes neglected the slave importation cases adjudicated in US courts during the period, not studying with sufficient depth the relationship between the freedom principle and the international slave trade.

Oakes' embrace of Fehrenbacher's characterization of an adamantly proslavery United States becomes even more curious when considering the recent rise to prominence of a historical narrative that emphasizes slavery's centrality to the United States' growth as a world power. At present, the historiography of the early republic and antebellum periods is conflicted over the degree to which emphasis must be placed on slavery as the roots of the US economic predominance of subsequent generations. A growing contingent of historians has, in numerous articles and monographs over the last decade, claimed that slavery was integral to the United States' growth as a world power. These New Historians of Capitalism, as they have come to be called, have painted a grim portrait of US history in which the principles of the Declaration of Independence - however noble — cannot be extricated from the cruelties of its contemporary contradiction, slavery. ${ }^{33}$

The arguments of these historians have been imbedded into the framework of the popular New York Times Magazine’s 1619 Project, which aimed to suggest that “Out of slavery,” as Jake

\footnotetext{
${ }^{32}$ Oakes, Freedom National, 529n8.

${ }^{33}$ See, for example: Walter Johnson, River of Dark Dreams: Slavery and Empire in the Cotton Kingdom (Cambridge, MA: Belknap Press of Harvard Univ. Press, 2013), 8-11; Edward E. Baptist, The Half Has Never Been Told: Slavery and the Making of American Capitalism (New York: Basic Books, 2014), xx-xxi; Sven Beckert, Empire of Cotton: A Global History (New York: Vintage Books, 2014), xii-xv.
} 
Silverstein wrote in his introduction to the project's introduction, "grew nearly everything that has made America exceptional. ${ }^{.34}$ As the narrative of these historians and non-historians has gained wider acceptance, the literature has drawn greater attention to the individuals who suffered as a result of slavery, while dismissing the role that antislavery - the movement to destroy entirely the institution — played in emancipation. ${ }^{35}$ For, while the slave trade may have brought its first cargo to the shores of the present-day United States in 1619, the trade subsequently continued for more than two hundred years. Emancipation, the precondition for general abolition, was a years-long process. The tale of the slave trade's destruction does not end with the 1808 importation ban, just as the stories of slavery and emancipation cannot be condensed into the years 1619 and 1863. Rather, these were the result of several actors, both free and enslaved, complex processes that cannot be presented in such a distilled manner.

To show this process more clearly, the historiography of abolition requires reconsideration. While in an American context "abolitionism" conjures images of William Lloyd Garrison and John Brown — whose immediatism seemed to fuel the slavocracy's rageabolitionism was a much more complex movement than suggested in the literature. As Richard S. Newman's 2002 study The Transformation of American Abolitionism exemplifies, the accepted narrative of abolitionism maintains that, with the rise of radical abolitionism, the traditional form withered away to extinction. Examining the Pennsylvania Abolition Society (PAS) and the Massachusetts Antislavery Society, which inspired the American Antislavery

\footnotetext{
${ }^{34}$ Jake Silverstein, "Why We Publish the 1619 Project," New York Times Magazine, December 20, 2019, https://www.nytimes.com/interactive/2019/12/20/magazine/1619-intro.html. Emphasis added.

${ }^{35}$ In its own way, Marcus Rediker's study of the Amistad case - which will be discussed in the second chapter of the present study - is less controversial example of this admirable trend to deemphasize the work of abolitionists, rejecting notions that the US legal system was in the slightest way noble. "Curiously," he writes, "the American legal system has emerged as the story's hero - the very system which, in 1839, held two and a half million African Americans in bondage. This triumphalism may be comforting to an American audience still haunted by the legacy of slavery, but it is deeply misleading." Marcus Rediker, The Amistad Rebellion: An Atlantic Odyssey of Slavery and Freedom (New York: Penguin Books, 2012), 5.
} 
Society, Newman divided abolitionism into two distinct "waves." The Pennsylvania society epitomized the gradualist approach of post-Revolutionary abolitionism. Newman argued, “dominated by societal elites - wealthy philanthropists, political representatives, businessmen, and, above all, well-known lawyers - the PAS advocated gradual abolitionism by means of painstaking legal work and legislative action." Contrary to radical abolitionism, "Emotional appeals to the public," he continued, "and religious zeal had no place in its procedure."36

Largely because of the PAS's elitism, according to Newman, the radical approach of the Massachusetts Antislavery Society became popular. ${ }^{37}$ The PAS "deplored" the immediatism of the "young upstarts" in Massachusetts, and many feared that "Massachusetts radicals would ruin the American republic before they destroyed slavery." ${ }^{38}$ Arguing that the Massachusetts Antislavery Society's rise to prominence was in response to the considerable social and political changes underway in the 1830s, Newman contended that "Abolitionism became the first social movement to so completely transform itself." 39

Newman's argument importantly neglected the continuities of earlier abolitionism into the antebellum period. His research questions, to some extent, explain this. Rather than study what elements of Revolution-era abolitionism lingered into the heyday of radical abolitionism, Newman hoped, through his research, to answer "why" abolitionism changed "when it did in the

\footnotetext{
${ }^{36}$ Richard S. Newman, The Transformation of American Abolitionism: Fighting Slavery in the Early Republic (Chapel Hill: Univ. of North Carolina Press, 2002), 4.

${ }^{37}$ Newman, The Transformation of American Abolitionism, 6. Newman summarized the radical abolitionist program: "Arguing that the PAS's republican style of reform was outdated in an increasingly egalitarian and romantic age, modern abolitionists emphasized the power of nonelites to halt slavery. Indeed, mobilizing the masses (including blacks and women), not careful legal and political planning, became the central abolitionist strategy after 1830. Only by opening up the movement to democratic activists and egalitarian sensibilities could reformers eradicate bondage. If enough people joined the abolitionist cause, Bay Staters argued, then the people themselves could compel governments to act - for instance, to amend the federal constitution to outlaw slavery, drop fugitive slave laws, and curtail racist laws." Newman, The Transformation of Abolitionism, 6.

${ }^{38}$ Newman, The Transformation of American Abolitionism, 7.

${ }^{39}$ Newman, The Transformation of American Abolitionism, 8-15.
} 
1830s" and "how exactly ... abolition's strategy and tactics change so that Americans would ever remember the aggressive post-1830s movement as the essence of organized antislavery." While continuities were surely not his focus, his research was framed in such a way as to prevent exploration of Revolutionary-era abolitionism's survival into the antebellum period. ${ }^{40} \mathrm{But}$ did, as Newman suggested, American abolitionism “completely transform itself”? Certainly, methodologically, the distinction between the two eras of antislavery is true. But, as an examination of the foreign slave trade shows, the legalistic strategies of traditional abolitionism continued into the Civil War.

This image of two distinct eras in antislavery has bled over into historiography of the coming of the Civil War. Although the antislavery movement began with attacks against the slave trade, the historiography of the Civil War's origins has largely focused on the radical strain of abolitionism that emerged in the 1830s. After the 1808 importation ban, it was not until the Missouri Compromise twelve years later that slavery surfaced again as a matter of federal concern. Antislavery, moreover, only became more popular after William Lloyd Garrison followed black abolitionists' lead in rejecting colonization and demanding immediate emancipation. ${ }^{41}$ But the dramatic deeds and passionate language of the American Anti-Slavery Society and immediate abolitionism have attracted historiographical emphasis. One need only briefly survey the literature of both abolition and the broader antebellum period to see that, with the arrival of these extreme actors, the older form of abolition seems to disappear. ${ }^{42}$ In treatments

\footnotetext{
${ }^{40}$ Newman, The Transformation of American Abolitionism, 2.

${ }^{41}$ Manisha Sinha, The Slave's Cause: A History of Abolition (New Haven, CT: Yale Univ. Press, 2016), 220.

${ }^{42}$ See James McPherson, Battle Cry of Freedom: The Civil War Era (New York: Oxford Univ. Press, 1988), 8, 88; Eric Foner, The Fiery Trial: Abraham Lincoln and American Slavery (New York: W. W. Norton, 2010), 18-22; Foner, Free Soil, Free Labor, Free Men: The Ideology of the Republican Party Before the Civil War (1970; New York: Oxford Univ. Press, 1995), 73-80; Howe, What Hath God Wrought, 648; Seymour Drescher, Abolition: A History of Slavery and Antislavery (New York: Cambridge Univ. Press, 2009), 300; David M. Potter, The Impending Crisis: America Before the Civil War, 1848-1861, ed. Don E. Fehrenbacher (1976; New York: Harper Perennial, 2011), 39-41.
} 
of the law in relation to the coming of the Civil War, the 1830 s has been similarly shown as a turning point. Immediatism has been shown entirely to replace gradualism. Rather than suggest continuity with the preceding fifty years, historians have suggested that antislavery legal arguments, particularly Somerset, were rediscovered. ${ }^{43}$ The distinct impression left upon the reader is that of a tight, thirty-year narrative that tells of the sudden rise of a sincerely driven, zealous abolitionism almost completely divorced from any moorings in Revolution-era antislavery.

This thesis intends to answer whether this earlier form of abolition truly disappeared by examining federal cases involving seized slave ships from 1820 to the Civil War. For how the slave trade went from a mere constitutionally promised ban to an eradicated commerce reveals an antislavery-minded US government not sufficiently addressed in the historiography.

\footnotetext{
${ }^{43}$ See William M. Wiecek, "Slavery and Abolition Before the United States Supreme Court, 1820-1860," Journal of American History 65, no. 1 (June 1978): 40; Finkelman, An Imperfect Union: Slavery, Federalism, and Comity (Chapel Hill: Univ. of North Carolina Press, 1981), 101; Finkelman, Supreme Injustice: Slavery in the Nation's Highest Court (Cambridge, MA: Harvard Univ. Press, 2018), 50-51; Kelly M. Kennington, In the Shadow of Dred Scott: St. Louis Freedom Suits and the Legal Culture of Slavery in Antebellum America (Athens: Univ. of Georgia Press, 2017), 174; Steven Lubet, Fugitive Justice: Runaways, Rescuers, and Slavery on Trial (Cambridge, MA: Belknap Press of Harvard Univ. Press, 2010), 25; Gordon S. Barker, Fugitive Slaves and the Unfinished American Revolution: Eight Cases, 1848-1856 (Jefferson, NC: McFarland \& Co., 2010), 1-20; Robert M. Cover, Justice Accused: Antislavery and the Judicial Process (New Haven, CT: Yale Univ. Press, 1975), 160-161. In a 1978 article, William M. Wiecek surveyed the abolition cases brought before the US Supreme Court from 1820 to 1860 and concluded that a rise in the number of cases after 1830 was the result the immediatist abolitionist societies. He prosaically mentioned that radical abolition societies "replaced the old, gradualistic societies," citing the two-year period of 1831 to 1833 as the timeframe in which the succession took place. While abolitionism is merely in the background throughout Paul Finkelman's An Imperfect Union, his narrative places the beginning of the 1830s as the turning point toward a more widespread Northern acceptance of the Somerset principle. His periodization thus reflects the historiographically accepted shift in abolitionism's methods. The lack of contextualization is rather startling. Similarly, Kelly M. Kennington's discussion of anti-abolitionist mobilization in response to growing antislavery activity in antebellum St. Louis is suggestive of abolitionism's change in tactics at the dawn of the 1830s. In Supreme Injustice, Finkelman rather suddenly introduced Garrisonian abolitionism and fails to root it in gradualism. Rather, gradualism was only discussed so far as the American Colonization Society-which he describes as "at most mildly antislavery." Immediatism suddenly appeared as an antislavery strategy with William Lloyd Garrison's publishing of the Liberator in 1831. Robert M. Cover emphasized the shift toward immediatism in Justice Accused, writing that "The development of immediatism in the abolitionist movement, the demise of servitude in the gradual emancipation states, and the bitter sectarian divisions of the abolitionist movement produced an impulse to use litigation as a dramatic forum for ideology. The qualitative difference in antislavery advocacy may be dated, rather imprecisely, to the 1830's. This development in legal strategy coincided with the rise of militant abolitionism."
} 
Historians' questions that probe the sincerity of constant slave-trade suppression diminish that, between 1808 and 1865, the US government seized and adjudicated illegally imported slave cargoes and prosecuted US citizens suspected of engaging in the trade. Regardless of their outcomes, these cases established, case by case, that the US government would go to trial over the international slave trade. Revealing an antislavery-minded US government not sufficiently addressed in the historiography, these cases lay bare a distinct portrait that joins the historiographies of US diplomacy, the coming of the Civil War, and abolitionism, rooting them in the traditional, legalistic antislavery of the nation's revolutionary founding. This thesis endeavors to look for continuities. And, in examining the slave trade, therefore, it will bridge a historiographical void.

Beginning in 1820, when, as Fehrenbacher suggested, Congress enacted the last "substantive legislation" against the international slave trade ${ }^{44}$ this project will show that Revolution-era antislavery did not die out with the rise of radical abolitionism in the 1830s. In its first chapter, "Origins: A Diplomatic Dilemma," the thesis will examine the case of the Jeune Eugénie to explain the motivation behind the federal government's apparent reluctance to join international efforts to police the slave trade. Seized by the US Navy off the coast of present-day Liberia in 1821, the ship became the subject of a diplomatic incident between the United States and France. Against considerable French pressure, the American republic asserted the sovereignty of its courts. Using diplomatic correspondence in addition to court reports, the chapter will maintain sovereignty's place as the priority of foreign policy in the early republic. The second chapter, "The Means and Ends: Freedom International?," will study the federal court cases in which slave ships or US citizens were tried for engaging in the illicit trade between 1820

\footnotetext{
${ }^{44}$ Fehrenbacher, The Slaveholding Republic, 152.
} 
and $1862 .{ }^{45}$ Relying on court reports, this chapter charts the construction of the abolitionist legal mechanism for emancipation in three vignettes, applying James Oakes' thesis in Freedom National to the international through the Atlantic slave trade. ${ }^{46}$ In the third and final chapter, "Character: The American Colonization Society, Abolitionism, and 'The Great Safety Valve of This Union!'," this thesis will explore the relationship between the American Colonization Society (ACS) and our understanding of abolitionism by emphasizing the antislavery nature of this largely dismissed gradualist organization. Using the annual reports and member publications of the ACS, the chapter will show that the society was an abolitionist organization and that antislave-trade concerns of traditional abolitionism continued well into the antebellum period. Together, these chapters will build a portrait of a long abolitionism, which, as Oakes suggested, slowly, yet constantly, drove toward emancipation. As Timothy Patrick McCarthy and John Stauffer identified in their 2006 Prophets of Protest, three questions have driven the historiography of abolitionism, with historians striving to explain the "when," "why," "how," and "who" of the movement's progression. These questions, which they named the "origins," "means and ends," and "character" debates, ${ }^{47}$ provide the structure of this thesis.

The early republic and antebellum periods were awash with contradictions. As it broadened suffrage and fostered opportunities for white males, the United States was, as Fehrenbacher concluded, a "slaveholding republic," which could not, regardless of its proactive pursuit of slave-trade suppression, completely shake loose its ties to the Slave Power. But the United States' motivations in pursuing slave-trade suppression cannot be ignored. Both as a

\footnotetext{
${ }^{45}$ For enumeration of cases examined, see Appendix A.

${ }^{46}$ The author recognizes that relying on court reports could skew the sample of cases as, for the most part, only appealed cases are reported. While there are likely many more cases than those cited, this study focuses on the building upon of abolitionist precedent. For a definitive portrait of the nature of federal slave trade cases, therefore, further research, outside the scope of this study, is required. The author invites further interrogation of this question.

${ }^{47}$ Timothy Patrick McCarthy and John Stauffer, introduction to Prophets of Protest: Reconsidering the History of American Abolitionism, ed. Timothy Patrick McCarthy and John Stauffer (New York: New Press, 2006), xvi-xvii.
} 
means of exhibiting its sovereignty as an independent nation and as a continuation of Revolution-era antislavery, the United States sincerely worked to foreclose the international slave trade. The 1808 importation ban was a promise of the Constitution and a tool by which abolition could progress. Emphasizing the United States' commitment to slave-trade suppression is not intended to diminish the contradictions of the nation's first eighty years or the suffering of those individuals who found themselves enslaved within a republic that professed liberty. It means to complicate the picture of an entirely acquiescent US government, which served as the slavocracy's puppet, and demonstrates that, in the end, the Revolution's abolitionist promise was fulfilled. The story that follows tells of the origins, means and ends, and character by which abolitionists undertook that constitutional commitment. 


\section{CHAPTER I: ORIGINS: A DIPLOMATIC DILEMMA}

At around two o'clock on the morning of November 26, 1821, John Quincy Adams was wide awake. Anxiety had overtaken the Secretary of State to President James Monroe as the threat of just one day prior grew on his conscience. Although he had been engaged in stressful negotiations with the French ambassador, the Baron Hyde de Neuville, for several months, Adams laid in bed, unable to sleep, for another three hours. After trying in vain for the rest that he so desperately needed, he took to his diary to record the events of the day before. Neuville, he recalled, had become enraged: "As a private individual he declared as his opinion that within three months American vessels would be detained in France." ${ }^{48}$ Threatening to seize US merchant ships, the French ambassador challenged the rights of a sovereign United States.

What spawned Neuville's statement were the recent seizures of French commercial vessels, in particular the ship La Jeune Eugénie, accused by the US government of participating in the African slave trade. These seizures, Neuville claimed, were without justification, leading him to declare them to be "outrages upon the flag and the national honor of France." Adams attempted to calm the French ambassador, indicating that he would relay Neuville's opinion to President Monroe. But his response had the opposite effect. Leaping to his feet, Neuville exclaimed, "if satisfaction is not made to France ... La France doit leur déclarer la guerre," and swiftly exited the secretary's office into the night without even his overcoat. ${ }^{49}$ This overcharged conversation between Adams and Neuville had coincided with diplomatic discussions between the United States and Britain over the suppression of the international slave trade. Britain, desiring its former colonies to aid in policing the trade, asked that the United States take an

\footnotetext{
${ }^{48}$ Memoirs of John Quincy Adams, Comprising Portions of His Diary from 1795 to 1848, ed. Charles Francis Adams, vol. 5 (Philadelphia: J. B. Lippincott, 1875), 415-416, https://hdl.handle.net/2027/hvd.32044013557053.

${ }^{49}$ Memoirs of John Quincy Adams, 415-416.
} 
active role in a European priority. But the seizure of the Jeune Eugénie — an act similar to what Britain's negotiations asked of the United States — had only weakened the young nation's diplomatic position. Thus, the United States' attempt to position itself as an equal of the two leading world powers had in fact placed it in a precarious diplomatic situation, offending one and highlighting how different it was from the other.

By 1821, Britain had long been the European beacon of antislavery. As early as 1772, Lord Mansfield's decision in Somerset v. Stewart held that slavery had no basis in English common law. Steven M. Wise called the decision "the opening salvo in a legal barrage that, within a century, splintered all of human slavery's bulwarks." ${ }^{50}$ It was not until 1808 , however, when Britain abolished slavery, that it truly thrust itself onto the world stage as the international enforcer of antislavery. Although the Royal Navy did not begin patrols off West Africa in earnest until 1819, it seized slavers within the first years of the abolition law. As the Royal Navy battled with Napoleon across the world's oceans, older ships policed the African coast for slavers. When the Napoleonic Wars had finally come to an end, the Royal Navy gradually increased the size of its efforts at suppressing the slave trade. ${ }^{51}$ The patrols continued throughout the nineteenth century, leading to estimates that, between 1811 and 1870, Britain was responsible for interrupting forty-three percent of the slave trade..$^{52}$

Critically, Britain led the international community in establishing slavery as a violation of an emerging system of international law. The European power set up admiralty courts with wideranging, international jurisdiction through which to adjudicate the seizure of slave vessels and

\footnotetext{
${ }^{50}$ Steven M. Wise, Though the Heavens May Fall: The Landmark Trial That Led to the End of Human Slavery (Cambridge, MA: Da Capo Press, 2005), 225; Karen Ordahl Kupperman, The Atlantic in World History (New York: Oxford Univ. Press, 2012), 107.

${ }^{51}$ Marika Sherwood, After Abolition: Britain and the Slave Trade Since 1807 (New York: I. B. Tauris, 2007), 114.

${ }^{52}$ Ronald Hyam, Britain's Imperial Century, 1815-1914: A Study of Empire and Expansion (New York: Palgrave MacMillan, 2002), 18.
} 
created the laws by which those courts carried out their duties. ${ }^{53}$ In 1816 , even before the Royal Navy's patrols had been conducted in full force, these courts ruled on 130 ships that Britain had seized as slavers. ${ }^{54}$ Despite "smacking" of imperialism, Lauren Benton and Lisa Ford have attributed the basis of modern international law to British efforts during the period. Britain, they wrote, "negotiated an impressive network of treaties designed to erect in piecemeal fashion what international opinion could not deliver on its own: an international ban against slave trading and piracy." ${ }^{55}$ Britain was guiding Europe toward antislavery, making British concerns European priorities. As David Eltis wrote, the British government was becoming the "self-appointed instrument of international opinion." ${ }^{56}$

France, however, had stood as one of Britain's leading obstacles in its efforts to suppress the slave trade. The French colonial system depended on slavery, and, in the post-Napoleonic period, French ships contributed a significant portion of the international traffic of slaves. The reluctance of the French colonial system to yield to the international mood of antislavery that consumed Europe following the Congress of Vienna was an annoyance to the British government. According to Nelly Schmidt, the French government preferred to maintain slavery in its colonies because of those colonies' economic importance. This dependence on its colonies for cane sugar and exclusive commerce encouraged an "uncommon immobility" within the French government to abolish slavery - the institution on which the French West Indies

\footnotetext{
${ }^{53}$ Jenny S. Martinez, The Slave Trade and the Origins of International Human Rights Law (New York: Oxford Univ. Press, 2012), 15.

${ }^{54}$ Sherwood, After Abolition, 114.

${ }^{55}$ Lauren Benton and Lisa Ford, Rage for Order: The British Origins of International Law, 1800-1850 (Cambridge, MA: Harvard Univ. Press, 2016), 147; David Brion Davis, Inhuman Bondage: The Rise and Fall of Slavery in the New World (New York: Oxford Univ. Press, 2006), 142; David Eltis, Economic Growth and the Ending of the Transatlantic Slave Trade (New York: Oxford Univ. Press, 1987), 86-87. For further reading on Britain's diplomatic relationship with France over the slave trade, see Paul Michael Kielstra, The Politics of Slave Trade Suppression in Britain and France, 1814-48: Diplomacy, Morality, and Economics (New York: St. Martin's, 2000). ${ }^{56}$ Eltis, Economic Growth, 209.
} 
survived. ${ }^{57}$ In 1821, therefore, the French government was merely a nominal supporter of the slave trade's suppression.

Having led the world with its constitutional promise to ban the importation of slaves in twenty years, the United States, on the other hand, had fallen behind. In 1806, Congress began debating the prohibition of the importation of slaves, which the Constitution mandated, passing the legislation in 1807-twenty-three days before Britain's abolition. Although the initial bill wished for the death penalty to be imposed upon those Americans found to own or captain vessels participating in the trade, the enacted law contained minimal punishments, which were rarely enforced. ${ }^{58}$ Whether from salutary neglect or due to the distractions of the War of 1812 , the United States continued not to enforce the importation ban throughout the 1810 s. With illegal importation still occurring, Congress enacted legislation in 1818, 1819, and 1820 that increased the penalties for slave importation. In 1821, US law maintained that it was piracy, subject to capital punishment, for any American-owned vessel or US citizen to participate in the slave

\footnotetext{
${ }^{57}$ Schmidt, Abolitionnistes de l'esclavage et réformateurs des colonies, 31. As Stein concluded, "The crumbling of the French colonial system did not end the French slave trade as modify it. Technically, the trade was outlawed in 1814-15, but in reality it continued until the second half of the nineteenth century." Stein, The French Slave Trade in the Eighteenth Century, 198. For further discussion of the effect of abolitionism on the French colonial system, see Caroline Oudin-Bastide's "Discous colonial et discours abolitionniste : entre passions et intérêts" and Lawrence C. Jennings' "Abolitionnisme, jeu politique et réforme : France, 1814-1848," both in Olivier Pétré-Grenouilleau, ed., Abolir l'esclavage: Un réformisme à l'épreuve (France, Portugale, Suisse, XVIII ${ }^{e}-X I X^{e}$ siècles) (Rennes, France: Presses universitaires de Rennes, 2008). And, for studies on abolitionist mentality in French society, see Lawrence C. Jennings, French Anti-Slavery: The Movement for the Abolition of Slavery in France, 1802-1848 (New York Cambridge Univ. Press, 2000), 286, and Sue Peabody, "There Are No Slaves in France": The Political Culture of Race and Slavery in the Ancien Régime (New York: Oxford Univ. Press, 1996), 33.

${ }_{58} 16$ Annals of Cong. 231 (1806), https://hdl.handle.net/2027/uc1.\$c227014; Slave Trade Prohibition Act of March 2, 1807, ch. 22, 2 Stat. 205, https://avalon.law.yale.edu/19th_century/s1004.asp; Finkelman, Slavery in the Courtroom, 212. Section four held the vague punishment that, if any American or US vessel brought into a US port slaves, those slaves "shall be forfeited to the United States, and shall be liable to be seized, prosecuted, and condemned in any of the circuit courts or district courts in the district where the said ship or vessel may be found or seized." Opposition to this punishment was largely from Southern delegates. James Holland, a representative from North Carolina declared, "In the Southern States slavery is generally considered as a political evil, and in that point of view nearly all are disposed to stop the trade for the future. But have capital punishments been usually inflicted on offences merely political? I believe not. Fine and imprisonment are the common punishments in such cases. The people of the South do not generally consider slavery as a moral offence." 16 Annals of Cong. 239.
} 
trade, bringing the nation's position on the issue in line with the European standard. ${ }^{59}$ In 1824 , however, the United States declined to ratify an 1823 agreement between itself, Britain, and France that aimed to coordinate the nations' suppression efforts, backing away from internationally policing the practice for twenty years and threatening its status as a "civilized" power. ${ }^{60}$ As Paul Finkelman observed, "At the same time the United States prohibited the trade, the British Parliament also took steps to end it." ${ }^{61}$ While Britain patrolled the seas, therefore, the United States almost seemed ambivalent toward the slave trade's end.

Historians have long disagreed about the causes of the United States' inactivity in the early years of slave-trade suppression. Revolutionaries in the study of diplomatic history, in particular Samuel Flagg Bemis, held that the Monroe Doctrine, characterized by republicanism and hemispheric limitations, represented the United States' primary foreign policy goals during the period. ${ }^{62}$ Later historians, such as Scott A. Silverstone and Gordon S. Wood, have delved deeper, however, suggesting that the United States' international focus was not to provoke Britain or France; the United States thus stood as a constant neutral party between the two nations, not yet having been accepted on the world stage. Wood insisted that, by the conclusion of the War of 1812, the United States felt secure as a state, marking an end to the idea common

\footnotetext{
${ }^{59}$ Finkelman, Slavery in the Courtroom, 218. It is noteworthy that Finkelman argues the United States not have sincerely policed the slave trade until the administration of Abraham Lincoln. Paul Finkelman, An Imperfect Union: Slavery, Federalism, and Comity (1981; Clark, NJ: Lawbook Exchange, 2013), 26.

${ }^{60}$ Samuel Flagg Bemis, John Quincy Adams and the Foundations of American Foreign Policy (New York: Alfred A. Knopf, 1948), 414; Paul Michael Kielstra, The Politics of Slave Trade Suppression in Britain and France, 181448: Diplomacy, Morality, and Economics (New York: St. Martin's, 2006), 124; James Oakes, Freedom National: The Destruction of Slavery in the United States, 1861-1865 (New York: W. W. Norton, 2013), 262.

${ }^{61}$ Paul Finkelman, Slavery in the Courtroom: An Annotated Bibliography of American Cases (Washington, DC: Library of Congress, 1985), 212. Emphasis added.

${ }^{62}$ Bemis, A Diplomatic History of the United States, $3^{\text {rd }}$ ed. (1936; New York: Henry Holt, 1950), 208.
} 
throughout the early republican period of an internationally vulnerable North American republic. ${ }^{63}$

Don E. Fehrenbacher and, more recently, Daniel Walker Howe, Matthew Karp, and James Oakes have argued that US abstinence in slave-trade suppression reflected the growing control of Southerners in foreign policymaking that came to characterize the antebellum period. Not eager to see the domestic trade collapse, Southerners, they have argued, steered the United States away from international suppression. This was in spite of the significant impact of growing foreign antislavery opinion on the United States. ${ }^{64}$ In 1821, the United States thus found itself at the intersection of two distinct approaches to international politics. At this time, the early republic's sense of self-doubt in the nation's permanence on the world stage coincided with the growing prioritization of domestic sectional interests in addressing the larger world.

Significantly, the works of Eliga Gould and Seymour Drescher have offered a lens through which suppression of the slave trade may be better seen as tied to sovereignty. The United States wished to be seen on the world stage as a sovereign nation that could exert its power over the Americas, free from the influence of its former colonial master. But the young nation still had to operate within European parameters. ${ }^{65}$ The Monroe Doctrine, Gould claimed, was, therefore, purely the encapsulation of the status to which the United States aspired. Rather

\footnotetext{
${ }^{63}$ Scott A. Silverstone, Divided Union: The Politics of War in the Early American Republic (Ithaca, NY: Cornell Univ. Press, 2004), 19; Gordon S. Wood, Empire of Liberty: A History of the Early Republic, 1789-1815 (New York: Oxford Univ. Press, 2009), 622.

${ }^{64}$ Don E. Fehrenbacher, The Slaveholding Republic: An Account of the United States Government's Relations to Slavery, ed. Ward M. McAfee (New York: Oxford Univ. Press, 2001), 203; Daniel Walker Howe, What Hath God Wrought: The Transformation of America, 1815-1848 (New York: Oxford Univ. Press, 2007), 312; Matthew Karp, This Vast Southern Empire: Slaveholders at the Helm of American Foreign Policy (Cambridge, MA: Harvard Univ. Press, 2016), 3; Oakes, Freedom National, 262. While Howe suggests that, during the administration of Andrew Jackson, the United States had "courted British opinion" for the benefit of US trade, he notes that Old Hickory was "implacable" on matters of slave-trade suppression. Howe, What Hath God Wrought, 361.

${ }^{65}$ Eliga H. Gould, Among the Powers of the Earth: The American Revolution and the Making of a New World Empire (Cambridge, MA: Harvard Univ. Press, 2012), 2.
} 
than the star it became in the American firmament, the Doctrine, to Gould, lacked any real-world implications. It was the declaration of a state that could only ward off European colonial interests as long as Europe was indifferent toward the Western Hemisphere. ${ }^{66}$

The United States, according to Gould, assented to Britain's interference with foreign vessels as it recognized the US Navy did not have the infrastructure to police its own importation ban. Despite contemporary debates over the impressment of American citizens, the United States allowed the British Navy to seize American slave ships. ${ }^{67}$ To contribute to the suppression of the international slave trade - a European priority — the United States thus sacrificed an aspect of its sovereignty to Britain. After all, to Gould, "Americans accepted the legal order of which Europe was still the center." ${ }^{68}$ And, as Drescher crucially noted, while the United States understood the realities of this system, its foreign policy was a constant balance between suppressing slave importations and resistance to British pressure to join an international coalition to do so. ${ }^{69}$ Although it accepted European priorities to ensure it was viewed as a notable world power, the United States had little desire to play a constant role in slave-trade suppression. It would only participate as a means of underscoring its worthiness as an unignorable sovereign state operating within the European system.

The instance of the Jeune Eugénie stood in curious contrast to the United States' pattern of inactivity. The diplomatic incident, which began after the ship's capture in mid-May 1821, reflects the framework of Gould and Drescher. When a US Navy ship seized the French-flagged La Jeune Eugénie off the coast of present-day Liberia, the United States, for a brief moment,

\footnotetext{
${ }^{66}$ Gould, Among the Powers of the Earth, 211.

${ }^{67}$ Gould, Among the Powers of the Earth, 165-166.

${ }^{68}$ Gould, Among the Powers of the Earth, 213.

${ }^{69}$ Seymour Drescher, Abolition: A History of Slavery and Antislavery (New York: Cambridge Univ. Press, 2009), 137.
} 
entered the international struggle against the slave trade. Although likely an American vessel that was undeniably engaged in the slave trade, the case of the Jeune Eugénie placed the United States at odds with one of its earliest European allies, France, exacerbating a previously deteriorating diplomatic relationship with the continental power. While it diplomatically insisted that the executive could not interfere with the case as it worked its way through the court system, the United States internally pushed the court to release the ship back to the French, despite evidence and codified law that demanded otherwise. Externally, therefore, the United States' integrity was maintained, while it ensured that its neutrality between Britain and France would not be disturbed. Only three years later, the United States forwent joining Britain in a coalition to rein in the slave trade. The years between 1808 and 1823 stood as a unique time for the United States and its desire to suppress the international slave trade, when early republican fears of the Union's permanence combined with rising antebellum tensions over the domestic slave trade. The case of the Jeune Eugénie thus serves as a case study for this early US approach to the suppression of the international slave trade; for, during this period, the United States participated in an international system, which it would later repudiate, in which its sovereignty found itself constantly on shaky ground.

When the USS Alligator intercepted the Jeune Eugénie in May 1821, its orders were not to police the African coast for slavers. In fact, the Alligator's primary mission had been at the behest of the American Colonization Society. Depositing a group of African American emigrants and an agent of the organization at Freetown, Sierra Leone, the Alligator joined several other US warships anchored in the harbor tasked with establishing a permanent West African colony for African Americans. While the officers of the other US Navy ships — in particular Edward Trenchard and Matthew C. Perry of the USS Cyane — had failed to convince local tribal leader 
King Peter to part with a concession on which an African American colony could be assured, they had encountered and seized American slave ships while scouting potential sites along the coast. The Alligator's captain, Robert F. Stockton, was determined, however, to obtain a concession from King Peter. Upon his arrival at Freetown, Stockton attempted to negotiate with King Peter. But, swiftly meeting the same obstacles that his predecessors had, he arranged a second, later meeting, which proved much more successful. Convincing the king to concede what would become Monrovia, Liberia, at gunpoint, he offered "guns, furniture, a bundle of mirrors, rum, and cigars worth about $\$ 300 "$ in exchange. ${ }^{70}$ Through coercion, the Alligator's official mission was accomplished. That primary objective, which supported the removal of free African Americans from the United States, importantly alludes to the increasing fragmentation of antislavery as the republic left its revolutionary era and entered the antebellum period.

Having successfully obtained land for an African American colony in West Africa, Stockton and his Alligator had time to join the other US Navy ships in their informal investigations of American slavers operating in the region. During his "negotiations" with King Peter in Freetown, Stockton had been informed of ships taking on slaves just inside the mouth of the Gallinas River, south of Freetown. Should those ships have been sailing either under American flag or with American crew members, they were acting in violation of US law and subject to Stockton's seizure. This intelligence was confirmed when, en route to the Gallinas, the Alligator picked up the crew of a small sloop, who had only recently left the two slavers anchored there. ${ }^{71}$ On the evening of May 17/18, the crew of the Alligator found the Jeune

\footnotetext{
${ }^{70}$ Siân Rees, Sweet Waters and Bitter: The Ships That Stopped the Slave Trade (Durham: Univ. of New Hampshire Press, 2011), 70-71. It is curious to note that, according to Rees, Stockton was a pugnacious young officer, whom King Peter had the misfortune to face. Only twenty-six years old in 1821, Stockton was a veteran of the War of 1812 - which allegedly made him exceptionally anti-British — and the winner of three duels over the course of just six months, each of which with a British officer. Rees, Sweet Waters and Bitter, 70.

${ }^{71}$ Robert F. Stockton, in A View of the Present State of the African Slave Trade, ed. Religious Society of Friends (Philadelphia: William Brown, 1824), 35,
} 
Eugénie anchored at the mouth of the Gallinas, near Cape Mount, just as the reports had suggested. They boarded and seized the vessel, marking the first prize of their cruise. ${ }^{72}$ Inspecting the ship, Stockton quickly identified the Jeune Eugénie to be a slaver. Reporting to US Secretary of the Navy Smith Thompson in July 1821, Stockton recalled that she was "in all respects prepared for the reception and accommodation of slaves; the decks laid, water stowed, and gratings for the admission of light and air, with a large quantity of rice and water on board." ${ }^{\prime 73}$ He continued, "The officer in command of the vessel declares that on discovering us, he made preparations to repel every attempt that would be made to discover who or what he was; an evidence sufficiently conclusive as to the nature of the business in which he was engaged." "74 Stockton's inspection revealed a ship whose object, he believed, was clearly to transport slaves. That no slaves were on board was purely a matter of fortunate timing and did not diminish Stockton's certainty. The Jeune Eugénie was undoubtedly a slaver whose "cargo" had simply not yet been loaded.

With enough provisions for the transport of slaves, the ship's structure further suggested that it had long been in use as a slaver. While the ship's papers claimed its journey was from Basseterre, Guadeloupe, to St. Thomas, and then to the coast of Africa for "the ostensible purpose of procuring palm oil and other products of Africa," two of Stockton's crew, who were later deposed, stated that the Jeune Eugénie had permanent structural alterations indicative of a slave ship. One midshipman noted that "The Eugenie had a moveable deck, that her main

\footnotetext{
https://books.google.com/books?id=5xcfH718YXIC\&lpg=PA33\&ots=PBCS3j_KaD\&dq=edward\%20trechard\%20a $\% 20$ view $\% 20$ of $\% 20$ the $\% 20$ present\&pg=PA1\#v=onepage\&q=edward $\% 20$ trechard $\% 20 \mathrm{a} \% 20$ view $\% 20$ of $\% 20$ the $\% 20$ present\&f=false.

${ }^{72}$ Stockton, in A View of the Present State, 40; William P. Mason, A Report of the Case of the Jeune Eugénie, Determined at the Circuit Court of the United States, for the First Circuit, at Boston, December 1821 (Boston: Wells \& Lilly, 1822), 3, http://hdl.loc.gov/loc.law/llst.057.

${ }^{73}$ Stockton, in $A$ View of the Present State, 40.

${ }^{74}$ Stockton, in $A$ View of the Present State, 41.
} 
hatchway was very large, and grated with three iron bars, that the water on board was sufficient to supply two hundred men for a month. And her provisions, including rice, enough for her crew for a twelve-month." Another crewmember, a seaman, noted the presence of handcuffs and fetters, which contradicted the owners' claim that the ship was sailing to obtain palm oil. ${ }^{75}$ Instead of carrying the cargo that the ship's log suggested, the Jeune Eugénie had been structurally modified to transport slaves, permanent alterations that had likely been used before. Obviously prepared for the transportation of slaves, the Jeune Eugénie's nationality was all that remained for Stockton to claim her as prize. Having inspected the vessel, Stockton was convinced that she was an American ship falsely sailing under French flag. Of course, that the Jeune Eugénie had been flying French colors before the Alligator's arrival had not stopped Stockton from proceeding with his search. However, the search yielded evidence that satisfied Stockton, showing the ship to be, in fact, still American owned and operated. He claimed in his report to Thompson that "although in her papers it is admitted that she was built in the U.S. they could not shew any legal proof of a transfer from her original owners."76

The documents that Stockton found aboard indicated she had belonged to Jean Pierre Raibaud and Jean Marie Labatut, French residents of Guadeloupe, since February $1819 .{ }^{77}$ At the time, Guadeloupe was an especially active center for the slave trade. Leading the slavery-

\footnotetext{
${ }^{75}$ Mason, Report of the Case of the Jeune Eugénie, 4.

${ }^{76}$ Stockton, in $A$ View of the Present State, 40.

${ }^{77}$ Mason, Report of the Case of the Jeune Eugénie, 10. Although the primary sources do not provide the first names of the alleged owners, brief genealogical research points to Jean Pierre Raibaud and Jean Marie Pierre Jules César Labatut, who were contemporary residences and merchants of Basse-Terre, Guadeloupe. Raibaud and Labatut were brothers-in-law, with Raibaud being married to Labatut's sister Geneviève. The Raibaud's first child was a boy named Eugène, born in 1811, suggesting that the ship was named "the young Eugène" after him as he would have been approximately ten years old. David Quénéhervé, "1808: 'Il n'est guère possible de faire des affaires en temps de guerre'; Lettre de Pierre Labatut," Généalogie et Histoire de la Caraïbe, 4 , https://www.ghcaraibe.org/articles/2012-art24.pdf. The family tree lists the professions of both as "négociants," a euphemism for slave trader, rather the common French word "marchand." According to Robert Louis Stein, "at least in theory, négociants were large-scale wholesalers who were quite different from small retailers or marchands." Robert Louis Stein, The French Slave Trade in the Eighteenth Century: An Old Regime Business (Madison: Univ. of Wisconsin Press, 1979).
} 
dependent French colonial system in slave importation, the island annually acquired an average of 38,000 enslaved persons. Only ten years earlier, Guadeloupe held its maximum enslaved population of $103,000 .{ }^{78}$ Meanwhile, French slavers led the world in the slave trade. One British officer, in fact, claimed that in the first half of 1820 he had encountered twenty-five to thirty slavers sailing under French flag, bearing an estimated total of 40,000 slaves. ${ }^{79}$ Regardless of whether they were genuine, the ship's papers suggested that she originated in the core of the slave-trading world. Destined for a slave-trading center and rigged for the transportation of slaves, the circumstantial evidence was plentiful that pointed to the Jeune Eugénie's status as a slaver. Not proven to have been legitimately transferred from American ownership, the Jeune Eugénie could be subject to US seizure and returned to the United States to be adjudicated as Stockton's prize.

Stockton's intuition as to the Jeune Eugénie's nationality seemed confirmed when, just one week later, on May 24, the Alligator seized two other schooners, the Daphnée and the Matilda. He reported to Thompson that "the former of which had a French flag flying at her main, and a Dutch flag at the foremast head, the latter having a French flag at her main." $" 80$ Satisfied that the ships' external appearances suggested American construction, he boarded them, convinced that "the colours she had hoisted were assumed for the occasion, and not true; for it

\footnotetext{
${ }^{78}$ Eltis, Economic Growth, 246; Nelly Schmidt, Abolitionnistes de l'esclavage et réformateurs des colonies: 1820 1851; Analyse et documents (Paris: Karthala, 2000), 34. Eltis's data shows that the decade of 1821-1830 was the peak of slave importation in French America, a point at which colonies such as Guadeloupe, Martinique, and French Guyana surpassed the pre-Haitian Revolution numbers of St. Domingue. Eltis, Economic Growth, 249.

${ }^{79}$ Gaston Martin, L'Histoire de l'esclavage dans les colonies françaises (Brionne, France: Gérard Monfort, 1948), 256.

${ }^{80}$ Stockton, in A View of the Present State, 35. Curiously, the seizures of the Daphnée and the Maltida brought with them further evidence that damned the Jeune Eugénie as a slaver. While observing the two ships from afar, Stockton's Alligator received a visit from a small boat, which proved to bear the Daphnée's captain. "Some short time after coming to an anchor, the commanding officer (Mr. Guoy) of La Daphnéé [sic], came on board of the Alligator, mistaking her for La jeune Eugené [sic]. Such information was obtained from him before he discovered his mistake, as confirmed the previous account I had received, and left no doubt that La Daphnéé was engaged in the slave trade." Stockton, in A View of the Present State, 35.
} 
was well understood that the slave trade had been denounced by both nations whose protection she appeared to claim." 81

Those familiar with the trade further confirmed Stockton's suspicion. Eli Ayers, the American Colonization Society agent whom Stockton transported to Freetown, wrote in 1823 that, "Although our flag has nearly ceased to be disgraced by this inhuman traffic, it is yet to be feared that much American capital is still employed in the trade under the protection afforded by the French and Spanish flags, as some of our citizens have occasionally been heard of on board of French and Spain vessels." 82 In the international slave trade, it seemed that nationality mattered only to the extent that it offered haven from punishment; and, since seizure was the worst punishment, to lose one's vessel meant to lose the potential profits that its human cargo might yield. What resulted was a culture of internationalism among those participating in the slave trade where national identities were only fickle facilitators of further profit.

Nevertheless, having assumed a French identity, the Jeune Eugénie threatened to guarantee the collapse of the already delicate relationship between the United States and France. From outward appearances, the case involved the seemingly unjust boarding and seizure of French citizens' private property. But the two nations' diplomatic relationship was in turmoil. Throughout June and July 1821, discussions between Adams and Ambassador Neuville revolved around the issue of US interference with French commercial vessels, particularly in the matter of the Apollon, which was then working its way through the federal court system. Caught off the coast of Florida, the Apollon was detained for attempting to avoid a tonnage duty by smuggling

\footnotetext{
${ }^{81}$ Stockton, in A View of the Present State, 36. He thus left Africa with four schooners as prize. Concluding his report, he wrote, "though I have not given actual liberty to more than two slaves, still I have great satisfaction in the reflection, that I have procrastinated the slavery of some eight hundred, and broken up this horrible traffic to the northward of Cape Palmas for at least this season." Stockton, in A View of the Present State, 36

${ }^{82}$ Eli Ayers to the US Secretary of the Navy, in A View of the Present State, 32.
} 
goods and specie into the United States through the St. Mary's River. Critically, mounting evidence indicated that the ship had acted with the backing of the French government.

Although eventually settled by the US Supreme Court in 1824, the matter was yet unsettled in the summer of 1821. Neuville pressed Adams that the Apollon matter be dropped for the sake of the most-favored-nation principle and the rights of French citizens. ${ }^{83}$ However, Adams was adamant that the US judicial system would not be subverted, especially against French pressure. Writing to Monroe about Neuville's reaction to hearing that the Apollon case would be taken to trial, Adams reported that "he seemed to be displeased that it had been brought. I told him that so far as private rights were concerned, the Judicial tribunals were entirely competent to their protection." 84 Prior to the Jeune Eugénie, Adams maintained that the US government would not bow to French demands, resolute that the federal judiciary was a manifestation of the nation's sovereignty.

The Jeune Eugénie's arrival in Boston on July 14 coincided with the nadir of Adams' conversations with Neuville regarding the Apollon. Thus, the foundation on which the increasingly difficult issue of the Jeune Eugénie would be discussed was exceptionally poor. In a letter to Monroe on July 25, Adams protested the expressive attitude that Neuville had adopted in his recent negotiations. "I cannot disguise to you," Adams wrote, "that if I have profoundly felt the conduct of Captain Edou [the Apollon's captain], as it effects the rights and interests of our Country, I have been much more indignant at the attempt of the Baron de Neuville to palm it off upon the World for the suffering of injured innocence and to trample upon the honour of this Nation, by exacting, upon the most paltry pretences [sic], that the American Government should

\footnotetext{
${ }^{83}$ The Apollon, 22 US 362 (1824); Bemis, John Quincy Adams, 451.

${ }^{84}$ John Quincy Adams to James Monroe, July 31, 1821, image 32, James Monroe Papers, Series 1: General Correspondence, 1758-1839, Reel 8, Library of Congress, Washington, DC, http://hdl.loc.gov/loc.mss/ms009142.mss33217.008.
} 
degrade itself, and, by the basest of concessions, set the seal to its own shame." ${ }^{\prime 5}$ Nearly a week later, Adams reported to Monroe that further negotiation on the matter was futile. He concluded, "there is nothing to negotiate upon. There is nothing but chicanery in the claim." ${ }^{" 86}$ Neuville and the Apollon matter had worn down Adams' patience. Adams saw Neuville's repeated requests as groundless deceit, frivolous irritants that had only proved to test his own diplomatic restraint. Although first only mentioned tangentially, as early as July 31, 1821, Adams' correspondence to Monroe referenced the Jeune Eugénie as the subject of his conversations with Neuville. ${ }^{87}$ As Stockton registered his claim with the US District Court of Massachusetts, therefore, the Jeune Eugénie became its own source of controversy that aggravated the difficult diplomatic situation. The Monroe administration once again became embroiled in discussions with a French government with whom its relations were fragile at best.

Once August 1821 had passed, the administration's internal correspondence delved deeper into the case of the Jeune Eugénie. In an attempt to diffuse the situation, Stockton's orders were conveyed to Neuville. Navy secretary Smith Thompson spoke with Neuville and assured him that no US Navy warships would have interrupted the travel of a ship without firm evidence suggesting it to have been a slaver. Undoubtedly, he recalled in a letter to Monroe on September 5, 1821, "the seizures in the cases referred to were made under a belief and strong impression (growing out of the inconsistancies $[\mathrm{sic}]$ and the wait [sic] of the usual documents to show they were French vessels) that they were American vessels and were seized as such." 88 Stressing that his orders only allowed US Navy ships the right to visit American vessels engaged

\footnotetext{
${ }^{85}$ Adams to Monroe, July 25, 1821, image 23, Monroe Papers, Series 1, Reel 8; New York Evening Post, July 17, 1821, https://www.newspapers.com/image/39632980/?terms=Evening\%2BPost.

${ }^{86}$ Adams to Monroe, July 31, 1821, image 32, Monroe Papers, Series 1, Reel 8.

${ }^{87}$ Adams to Monroe, July 31, 1821, image 32. Monroe Papers, Series 1, Reel 8.

${ }^{88}$ Thompson to Monroe, September 5, 1821, image 81-82, Monroe Papers, Series 1, Reel 8.
} 
in the slave trade, he wrote, "The general instructions to all our ... vessels authorize them to take only American vessels concerned in slave trade where found without the waters of the U. S." 89 While it maintained that Stockton's seizure was justified, the US government displayed a keen interest in quickly resolving the building diplomatic incident by parsing out the Alligator's orders. What thus resulted was an implied portrait of Stockton as a rogue officer, which aimed to salvage the United States' position with France.

The secretary's letter, more importantly, revealed an avowed position within Monroe's cabinet to concede to the French government's demands. Thompson's letter exposes a skepticism as to Stockton's evidence for seizing the Jeune Eugénie. He admitted, “The documents said to have been produced to show they were French I have not seen. If Mr. Adams on examination should be satisfied that the owners were Frenchmen I should think the most advisable course would be to give up without trial." He continued, "The Government might be under obligation to make them a compensation. There however would be no object as it would be much more acceptable to the French Government so far as they might deem their natural rights invaded to have the vessel delivered up voluntarily than by decree of the Court." ${ }^{90}$ Despite not having the chance to review the evidence with which Stockton had justified the Jeune Eugénie's seizure, Thompson urged the matter's expeditious resolution, fearing the possible diplomatic consequences. Although he feigned deference to the opinion of Monroe's senior foreign policy advisor, Thompson advocated that the administration deliver the ship to the French without having its ownership properly adjudicated in the federal court system. In its discussions with the French government, therefore, the Monroe administration supported Stockton's actions, defending his seizure, while internally maintaining that the matter needed to be swiftly rectified.

\footnotetext{
${ }^{89}$ Smith Thompson to Monroe, September 5, 1821, image 81, Monroe Papers, Series 1, Reel 8.

90 Thompson to Monroe, September 5, 1821, image 82, Monroe Papers, Series 1, Reel 8.
} 
Thompson was, by no means, alone. Monroe, too, was eager that the controversy be put behind him. Materializing as General Andrew Jackson's heavy handed governorship was creating increasing tension between Spanish Floridians and their American occupiers, the Jeune Eugénie affair was far from a foreign policy success. In his diary, Adams noted a conversation with Monroe and John C. Calhoun, the US Secretary of War, regarding the latest updates on both situations. "I had some desultory conversation with him concerning the case of the French vessel La Jeune Eugénie and Lieutenant Stockton, and also concerning Jackson's transactions with Callava and Fromentin." Although these were "all subjects of very insignificant import in themselves, but very important from circumstances and principles connected with them," Adams stressed that "The President is not a little embarrassed with them." $" 91$ Monroe's embarrassment hinted at a fear of the strength of the United States' sovereign image.

Hoping to avoid further international disputes, Thompson went further to prevent future incidents similar to that of the Jeune Eugénie. He ordered Stockton not to seize any vessel flying a foreign flag, severely limiting the Alligator's potential to police the slave trade while showing timidity amid a conflict with a major European power. In a letter to Monroe on September 15, 1821, Thompson indicated that Stockton had again set sail. This time, however, he bore more specific orders. Referring to the orders that Stockton received prior to his departure for Africa, Thompson explained, "I had ordered him not to seize or interrupt any vessel under a foreign flag unless he had the strongest and most satisfactory evidence that she was American, and using the flag as a mere cover." He continued, stressing a key change: "I have again to day instructed him

${ }^{91}$ Memoirs of John Quincy Adams, 366. The incident to which Adams referred was Jackson's imprisonment of José María Callava, the former governor of Spanish Florida. Eligius Fromentin, appointed by Monroe to serve as Judge for West Florida, had issued a writ of habeas corpus, which Jackson overturned, claiming it to have "interfered with his authority." By the time that Adams discussed the matter with Monroe and Calhoun on September 15, newspapers across the country had published the correspondence of Jackson and Fromentin complaining to the Monroe administration about one another. But the press had rallied behind Jackson. Memoirs of John Quincy Adams, 359. 
for the present and until further orders not to seize or search any vessel under a foreign flag." 92 To Thompson, caution — more specifically, avoiding conflict with France-was much more important than stopping the slave trade.

Unlike Thompson, the nation's senior diplomat saw little reason to change the Navy's behavior. More familiar with Neuville's emotional demands, Adams urged the cabinet to avoid concessions and let the trial run its course. Stockton, Adams was convinced, had acted correctly. Hypothesizing about the consequences of yielding unquestioningly in a letter to Monroe, Adams wrote, "I wish it should be submitted to the consideration of the President how this can be done without a strong, though tacit censure of Lt. Stockton." He continued, "By giving up the vessel we not only admit the fact, that she was entirely French property, but we deprive our officer of the means of shewing judicially his reasons for believing her to be American-We surrender not only the question of public right, but the justification of the individual." ${ }^{93}$ Rather than immediately handing over the Jeune Eugénie to the French, Adams argued that the case be settled in court. He stressed, "I am confirmed in the opinion, that the Jeune Eugénie should be left to the regular course of the law, without the inference of the Executive." 94 Seeing the importance of the United States' solid support of Stockton's actions, Adams recommended that the trial be held as any other. The representation of a sovereign United States, the US justice system could not succumb to the slightest push of a foreign power.

\footnotetext{
92 Thompson to Monroe, September 15, 1821, image 92, Monroe Papers, Series 1, Reel 8. Emphasis added.

${ }_{93}$ Adams to Monroe, September 22, 1821, image 102, Monroe Papers, Series 1, Reel 8.

${ }^{94}$ Adams to Monroe, September 19, 1821, image 97, Monroe Papers, Series 1, Reel 8. Emphasis added. Whether Adams supported Stockton's actions as the result of antislavery sentiment is unclear. Analyzing Adams' diplomatic career, Samuel Flagg Bemis discussed the matter of the Jeune Eugénie as part of a larger discussion of the idea of "equity of commercial opportunity," his vision of international free trade. Although he noted Adams' antislavery inklings, which, he claimed, appeared as early as the mid-1810s, Bemis believed that the Jeune Eugénie case was merely a tool by which the French government aimed to achieve most-favored-nation treatment with the United States, with which it hoped "to build up her merchant marine, which simply could not compete successfully with the American flag without the aid of special favors." Crucially, however, to Bemis, the Jeune Eugénie was "not proved to be a slave-trader." Bemis, John Quincy Adams, 416, 451.
} 
In spite of Adams' opinion, the cabinet continued to debate the use of executive authority prior to the trial's conclusion as a means by which the controversy could be brought to an end. Significantly, Thompson had, by the trial's commencement on October 29, altered his position, arguing instead that Monroe should not use his authority to interrupt the proceedings. While a faction still existed within the cabinet that advocated the trial be left to go unfettered, the cabinet was divided on the merits of the issue. Monroe, Calhoun, and Treasury secretary William H. Crawford — all Southerners-favored presidential interference. According to his own account, Adams again urged caution and proposed a compromise between the two sides:

I suggested ... that the District Attorney should be instructed to make a suggestion to the Court, that the French Minister had demanded the delivery of the vessel as a French vessel, amenable only to the jurisdiction of French tribunals, and that the President considered the claim to be well founded; the Court would act upon this suggestion as they should think proper. If they should decide to deliver up the vessel, the claim of the French Minister would be admitted, and the question at an end. If they should maintain their own jurisdiction and condemn the vessel, they would assign reasons for their decision, which would be subject to reversal or revisal by the Supreme Court of the United States, and furnish the answer to be given to the claim on the part of France..$^{95}$

The US government would, therefore, relate the French demands to the court to allow a fuller picture of the case. As the attorney general, William Wirt, was still hesitant, Adams recommended that an official opinion be written on the matter to ensure solidarity within the cabinet. Wirt concluded that "It is, therefore, no interference with judicial authority and independence; it is, in truth, as it is called, a suggestion merely of the true character of the case, as it has been presented by the minister of a foreign sovereign; of the official demand of the

\footnotetext{
${ }^{95}$ Memoirs of John Quincy Adams, 380-381; National Intelligencer (Washington, DC) November 5, 1821, https://link-galecom.libproxy.lib.ilstu.edu/apps/doc/GT3017507640/NCNP?u=ilstu_milner\&sid=NCNP\&xid=9cdc739c. Curiously, however, Crawford articulated that France's behavior emphasized a lack of commitment to the trade's suppression. "The papers decisively proved," Crawford claimed, "the insincerity of France in her pretended abolition of the slave-trade; for here it appears that these vessels had undergone the examination of the French cruisers stationed upon the coast, and passed inspection by them as engaged in lawful trade." That the Jeune Eugénie left Guadeloupe unmolested by the French port authorities when she bore clear signs of being a slaver was indicative of French ambivalence as to the slave trade's suppression. Memoirs of John Quincy Adams, 391.
} 
vessel by that minister in the name of his sovereign, as not amenable to our tribunals."96 Through this compromise the government would appear to be actively trying to remedy the diplomatic crisis, while maintaining the court's integrity.

Temporarily, this compromise seemed to allay tensions. As a conversation between Adams and Neuville suggested, the letter that Adams drafted and sent to the US District Attorney in Boston regarding the case put Neuville at ease. When Adams read the letter to Neuville, he observed Neuville "to be entirely satisfied." Neuville remarked, "if the vessel was engaged in the slave-trade, nothing was farther from his disposition than to screen the concerned from punishment; for France was perfectly agreed with the United States both in the principle of suppressing the slave-trade and in that of refusing to agree to the right of search in time of peace." 97 As a world power, France had adopted the European priority of the slave trade's suppression, publicly maintaining its support of the endeavor.

Whether Neuville's words concerning French cooperation were sincere would only be answered as the court case dragged on. With time, Adams found it increasingly difficult to hold off Neuville's persistent antagonism. In his frequent visits to Adams' office throughout October and November, Neuville repeatedly explored already trodden ground. Adams, familiar with Neuville's tendency toward exaggeration, adopted a strategy of powerlessness, insisting that the executive could not interfere with the judiciary more than it already had in the letter it sent to the court the previous month. On November 1, Adams "told him that the President had been constantly inclined, from the time when he first made the demand, that the vessel should be delivered up, but that the capture had been made on the presumption that she was an American

\footnotetext{
${ }^{96}$ Executive Practices in Certain Cases, 1 Op. Att'y Gen. 505-506 (1821). https://heinonline.org/HOL/P?h=hein.agopinions/oag0001\&i=497.

${ }^{97}$ Memoirs of John Quincy Adams, 398.
} 
vessel; and the case was regularly before the judicial tribunal, from which the President had no power to take it." 98 The judiciary, as an equal branch of the federal government, could not be interfered with by the executive. Adams' position reflected an attempt to show solidarity amid external pressure.

In Paris, the French government was simultaneously becoming more forceful in its dealings with the American ambassador, Albert Gallatin. When the Baron Pasquier, the French foreign minister, spoke with Gallatin on the subject on November 16, he accused the Alligator of piracy. Although Gallatin defended Stockton's actions, stating that the evidence indicated the Jeune Eugénie to have been American owned and outfitted for the slave trade, Pasquier claimed that the French government could not possibly recognize the authority of another nation's courts. He declared, "since it was the act of an officer of the United States, there could be no pretence [sic] for a trial before a court, and government might and ought at once to have ordered an immediate restitution." ${ }^{99}$ The United States government, however, stood firm, determined that its courts had jurisdiction to try the case.

On November 25, this French hostility reached its climax when Neuville suggested that the French would declare war. It fell to Adams to convey the message to Monroe. At one o'clock on the afternoon of November 26, Adams met with the President at the White House to host Stratford Canning, the British ambassador. ${ }^{100}$ As soon as Canning departed, Adams relayed the conversation of the day prior to a "surprised and quite indignant" Monroe. The two agreed to alter the language of the president's state of the union address, to show "the real state of things,"

\footnotetext{
${ }^{98}$ Memoirs of John Quincy Adams, 378.

99 Albert Gallatin to Adams, Paris, November 16, 1821, The Writings of Albert Gallatin, vol. 2, ed. Henry Adams (Philadelphia: J. B. Lippincott, 1879), 213-214, https://hdl.handle.net/2027/uc2.ark:/13960/t47p8tn6b.

100 Memoirs of John Quincy Adams, 416.
} 
noting that "with the exception of the disagreement upon the commercial negotiation our relations with France are friendly." ${ }^{101}$

Calling a cabinet meeting the following day, Monroe stressed that the United States could not be viewed as the instigator. Insisting that France be seen as "in the wrong," the President hinted at the United States' precarious position in world affairs. "He believed that we could not have a quarrel with any one member of the Holy Alliance without bringing down the whole body of them upon us," wrote Adams. "They all hated us for our principles. They dreaded the effect of our example, the standing refutation of their doctrines in our prosperous condition, and the danger to themselves in our constantly growing power." 102 The Monroe Administration thus saw the case of the Jeune Eugénie as dangerous to the United States' position in world affairs. Although it believed that the United States was becoming a world power, Monroe's administration believed that the case of the Jeune Eugénie held the potential to upend the sovereignty of the United States.

The stability of Franco-American relations largely depended on the trial's outcome. But Justice Joseph Story, who presided over the trial at the US District Court of Boston, was a dangerous variable in a case with such tremendous implications. Only two years earlier, in 1819, Story's Charge to the grand juries of Boston and Providence, published and circulated across the United States, condemned the slave trade, codifying his antislavery convictions and dubbing it the "most detestable traffic." Greed had infested the human heart, leading many individuals to value the accumulation of wealth over the inhumanity of the trade. Noting the "severe" punishments for slave-trading, Story wondered, "Under such circumstances it might well be

\footnotetext{
${ }^{101}$ Memoirs of John Quincy Adams, 417.

${ }^{102}$ Memoirs of John Quincy Adams, 424. Monroe's state of the union address alluded to the discord with France. "It is my duty to state, as a cause of very great regret, that very serious differences have occurred in this negotiation." 38 Annals of Cong. 13 (1821), https://hdl.handle.net/2027/uc1.\$c227036.
} 
supposed that the Slave Trade would in practice be extinguished; - that virtuous men would by their abhorrence stay its polluted march, and wicked men would be overawed by its potent punishment." He concluded, "Avarice has grown more subtle in its evasions; and watches and seizes its prey with an appetite quickened rather than suppressed by its guilty vigils." ${ }^{103}$ As a publicly avowed antislavery moralist, whether Story would be able to render a shrewd verdict was unclear.

Story's views on the United States' role in the suppression of the slave trade seemed to present further cause for worry. In 1819, Story had suggested a desire that the United States be more proactive in the slave trade's suppression. "The government of Great Britain," he declared, "has indeed employed the most indefatigable and persevering diligence to accomplish this desirable object; and treaties have been made by her with all the principal foreign powers, providing for a total abolition of the trade within a very short period." He continued, "May America not be behind her in this glorious work; but by a generous competition in virtuous deeds restore the degraded African to his natural rights, and strike his manacles from the bloody hands of his oppressors." ${ }^{104}$ Commending Britain's actions in suppressing the trade, Story urged the United States not to tarry in contributing toward that end. He was, therefore, a professed proponent of the proactivity that brought the Jeune Eugénie before his bench.

History and religion, Story believed, justified the slave trade's suppression. After all, the United States had liberated itself from its former colonial masters: "We boast of our noble struggle against the encroachments of tyranny, but do we forget that it assumed the mildest form in which authority ever assailed the rights of its subjects; and yet that there are men among us

\footnotetext{
${ }^{103}$ Joseph Story, A Charge Delivered to the Grand Juries of the Circuit court, at October Term, 1819, in Boston, and at November Term, 1819, in Providence, and Published at Their Unanimous Request (Boston: unidentified publisher, ca. 1819), 5, https://lccn.loc.gov/05041375.

${ }^{104}$ Story, A Charge, 5.
} 
who think it no wrong to condemn the shivering negro to perpetual slavery?"105 Having shaken itself loose of the shackles of a "tyrannical" Britain, whether the United States should increase its role in halting the slave trade was, to Story, self-evident. Christianity further dictated that humans treat one another with much more respect than the trade allowed. "There are men calling themselves Christians who degrade the negro by ignorance to a level with the brute, and deprive him of all the consolations of religion. He alone of all the rational creation, they seem to think, is to be at once accountable for his actions, and yet his actions are not to be at his own disposal; but his mind, his body, and his feelings are to be sold to perpetual bondage." He concluded, "To me it appears perfectly clear that the slave trade is equally repugnant to the dictates of reason and religion, and is an offence equally against the laws of God and man." ${ }^{106}$ As a Christian nation, the United States needed to choose the "civilized" path of suppressing the slave trade.

Even in 1819 , however, Story was aware that an outright condemnation of slavery would exacerbate the domestic political situation. Although he hated that the institution existed in the United States, he carefully avoided blaming contemporary Southerners. "It is to be lamented indeed, that slavery exists in any part of our country," he expressed. "But, it should be considered that it is not an evil introduced in the present age. It has been entailed upon a part of our country by their ancestors; and to provide a safe and just remedy for its gradual abolition, is undoubtedly as much the design of many of the present owners of slaves, as of those philanthropists who have labored with so much zeal and benevolence to effect their emancipation.” Slavery had been thrust upon contemporary Southerners, but strides were nevertheless being made to improve the institution and limit its scope. He thus patriotically emphasized the United States' global role as the originator of the institution's demise. “To our

\footnotetext{
105 Story, A Charge, 6.

106 Story, A Charge, 6.
} 
country belongs the honour as a nation, of having set the first example of prohibiting the further progress of this inhuman traffic." ${ }^{\prime 107}$ Story knew that the slave trade threatened a fragile domestic political landscape. As such, despite his famous denunciation of slavery and praise of British efforts to suppress the slave trade, in his Charge, Story revealed a willingness to sacrifice the morally correct path for the larger cause of the nation's continued stability.

When he ruled on the Jeune Eugénie, Story followed the same pattern as his renowned Charge, beginning by condemning the slave trade. To Story, that the ship was a slaver was undeniable. Pointing to her false deck, extraordinary amount of provisions, and the number of arms aboard, Story declared, "If there are any persons, who entertain doubts as to the real destination and employment of this vessel, I profess myself not willing to be included in that number." He continued, "Upon the evidence in the case it is irresistibly established to my mind, that the sole purpose of the voyage was a traffic in slaves; and that the intention was to carry them from Africa to some one of the French colonies, and, in all probability, to the port, in which the enterprise originated." 108 The Jeune Eugénie was, as far as the US judiciary was concerned, a slave ship.

Whether the Jeune Eugénie had been legitimately conveyed to Raibaud and Labatut, however, was never sufficiently established. And the evidence that the two Guadeloupeans presented far from convinced Story. Referring to the laws of 1818, 1819, and 1820, Story believed that Americans would naturally try to hide their citizenship to avoid US prosecution. "If

\footnotetext{
${ }^{107}$ Story, A Charge, 4.

${ }^{108}$ United States v. the La Jeune Eugenie, 2 Mason 409, 26 F. Cas. 832, 840 (C.C.D.Mass., 1822) (No. 15,551). Because the stability of the Franco-American relationship depended on the trial's outcome, the decision was highly anticipated. Corresponding with Story, Webster wrote, "Everybody is in expectation here of receiving your opinion in the case of 'The Young Eugenie.' It must come out, and that soon. I beg you to tell Mason either to publish it at once in a pamphlet, or to let Hale publish it in the paper." Daniel Webster to Joseph Story, Philadelphia, January 23, 1822, in the Private Correspondence of Daniel Webster, vol. 1, ed. Fletcher Webster (Boston: Little, Brown, 1876), 314, https://hdl.handle.net/2027/uc2.ark:/13960/t3319s98q. It should be noted that this volume incorrectly shows Webster to have written the letter on January 23, 1821 — five months prior to the Jeune Eugénie's seizure.
} 
American citizens were engaged in the traffic, it is manifest, that they would conceal their interests under a foreign flag and passports, and wear any disguises, which might facilitate their designs and favour their escape from punishment," he explained. Any claim that the ship was no longer American, therefore, required further investigation as "such disguises might be cheaply bought, and promptly obtained through the instrumentality of private agents in foreign countries, who would be ready to assume a nominal ownership, no one, that has been much acquainted with the real business of this commerce, would be inclined to doubt or deny." Unable to prove their ownership, Raibaud and Labatut's claims were deemed illegitimate. ${ }^{109}$

The ship was also never proved to be still under American ownership, however. Without proof showing such, the Jeune Eugénie was not subject to the piracy provisions of the act of 1819, making Stockton's claim for prize impossible. But the proof was unlikely ever to surface. As Paul Finkelman explained, "The ship had been involved in the slave trade, so the secret American owners did not come forward to claim the ship and perhaps contest the case." 110 While the French citizens who possessed the ship at the time of its seizure were not its proper owners, any American person who may have held title to the vessel remained unidentified. The Jeune Eugénie was thus a nationless ship, ambiguously tethered to an abstract international jurisdiction, whose future was almost as unclear as its past.

Although impossible to determine with certainty whether the United States held national jurisdiction, Story was tasked with the responsibility of finding some resolution. He nevertheless noted the potential controversy that his decision might bring. "The case has already, as we are informed, and truly, become the subject of diplomatic intercourse between our government and

\footnotetext{
${ }^{109}$ La Jeune Eugenie, 26 F. Cas. 841.

${ }^{110}$ Finkelman, Slavery in the Courtroom, 220. Finkelman described Story's position in deciding the case as a "dilemma," for no conclusion could be drawn as to its nation of ownership. He nevertheless suggested that Story had "good reasons to believe the ship was actually owned by US citizens."
} 
that of France," he observed. "It is not, perhaps, too much magnifying its grave character to declare, that rarely can a case come before a court of justice more deeply interesting to the cause of general justice and humanity, or more likely to excite the jealousies of a foreign government, zealous to assert its own rights ... It is bound to administer the law, as it finds it, fearlessly and faithfully." 111 Holding that the ship would be delivered to the French government for prosecution, Story wrote: "It enables the foreign sovereign to exercise complete jurisdiction over the case, if he shall prefer to have it remitted to his own courts for adjudication. It enforces the policy, common to both nations, of repressing an odious traffic, which is denounced by both." 112 Both the United States and France were publicly committed to suppressing the international slave trade, and, Story argued, the enforcement of either nation's laws would serve that interest.

Importantly, underneath this decision lie suggestions of an interest in distancing the United States from that responsibility. He continued, "It makes our own country, not a principal, but an auxiliary in enforcing the interdict of France, and subserves the great interests of universal justice." ${ }^{113}$ The United States would pass whatever burden remained for punishing Raibaud and Labatut, as well as any prize of the Jeune Eugénie, to France, for, as Story claimed, "the American courts of judicature are not hungry after jurisdiction in foreign causes, or desirous to plunge into the endless perplexities of foreign jurisprudence." ${ }^{114}$ Although also committed to the suppression of the international slave trade, the United States eagerly retreated on the issue, allowing another nation to resolve it instead.

Aware of slavery's potential to divide the nation, in his opinion in the Jeune Eugénie case, Story painstakingly created a dichotomy between domestic and international slave trades.

\footnotetext{
${ }^{111}$ La Jeune Eugenie, 26 F. Cas. 840.

112 La Jeune Eugenie, 26 F. Cas. 850.

${ }^{113}$ La Jeune Eugenie, 26 F. Cas. 850. Emphasis added.

${ }^{114}$ La Jeune Eugenie, 26 F. Cas., 851.
} 
While Story denounced what he repeatedly emphasized was the slave "trade," he did not condemn the institution itself. For Story believed that the trade was, in practice, inhuman. Analyzing whether the trade could be found in the law of nations, Story wrote, "It begins in corruption and plunder, and kidnapping. It creates and stimulates unholy wars for the purpose of making captives. It desolates whole villages and provinces for the purpose of seizing the young, the feeble, the defenceless, and the innocent." He concluded, "It stirs up the worst passions of the human soul, darkening the spirit of revenge, sharpening the greediness of avarice, brutalizing the selfish, envenoming the cruel, famishing the weak, and crushing to death the broken-hearted."115 The international slave trade was, according to Story, a different practice than what took place within the United States. Thus, as in his Charge, Story's opinion revealed a fear of the domestic political situation.

Story briefly alluded to the inherent contradictions of an otherwise dualist policy early in his opinion. While the United States would endeavor to suppress the international slave trade, it would maintain its domestic slave trade. "That [the slave trade] has interwoven itself into the municipal institutions of some countries, and forms the foundation of large masses of property in a portion of our own country, is known to all of us," he wrote. "Sitting, therefore, in an American court of judicature, I am not permitted to deny, that under some circumstances it may have a lawful existence; and that the practice may be justified by the condition, or wants, of society, or may form a part of the domestic policy of a nation." ${ }^{116}$ A desire for the least incendiary path possible may well have motivated Story's decision. In a way, his opinion reflected the intricate workings of a deft legal mind diligently laying out his argument, treading as lightly as possible.

\footnotetext{
115 La Jeune Eugenie, 26 F. Cas. 845.

${ }^{116}$ La Jeune Eugenie, 26 F. Cas. 845.
} 
But, just like the nation he served, considerations of national union superceded his commitment to the slave trade's destruction.

Presenting his conclusions in this way, Story’s opinion offered room for broad interpretation, ensuring the United States' position as a sovereign nation. As an anonymous "Notes" article in the Harvard Law Review observed, "On one hand, Story and other opponents of slavery described the opinion as a denunciation of the slave trade under international law," but, also, "The decision could stand for a sovereign country's right to be free from interference with its regulation of slavery because Story's opinion suggested that courts should not adjudicate captures of foreign slavers." ${ }^{117}$ Most importantly, as Finkelman argued, "Story's solution avoided a confrontation with the nation's oldest ally over the ownership of the vessel."118 The case of the Jeune Eugénie was simply not the opportunity in which the United States wished to risk its sovereignty. The Jeune Eugénie episode stood, to the Monroe Administration, therefore, as a lasting example of the need for prudence. Despite evidence clearly pointing to the ship as a slaver, Attorney General Wirt recalled, 'It was determined in the case of the 'Jeune Eugénie' that we had no right to meddle with the flag of France." 119 Whether it was a matter of "right" was doubtful; whether it was a matter of will was certain.

On February 2, 1822, Ambassador Gallatin wrote to John Quincy Adams of disturbing news that he had received from the British minister to France. "The British ambassador had made a few days ago a remonstrance to this government with respect to one of the prizes of the Alligator, retaken by the crew and carried to Guadeloupe, whence she is said to have sailed again

\footnotetext{
117 “International Norms and Politics in the Marshall Court's Slave Trade Cases," Harvard Law Review 128, no. 4 (February 2011): 1194-1195, https://www.jstor.org/stable/24643961.

${ }^{118}$ Finkelman, Supreme Injustice: Slavery in the Nation's Highest Court (Cambridge, MA: Harvard Univ. Press, 2018), 128.

119 Restoration of Africans Recaptured from Pirates, 1 Op. Att'y Gen. 535 (1822), https://heinonline.org/HOL/P?h=hein.agopinions/oag0001\&i=527.
} 
for Africa with the American crew on board, and to have brought back a cargo of slaves to Guadeloupe." ${ }^{120}$ Within a month after Story released his decision, the Jeune Eugénie sailed again to bring to Guadeloupe the human cargo of which the Alligator robbed it—a truly avoidable and unfortunate end.

The case of the Jeune Eugénie marked the first significant US foray into international slave-trade suppression. It would not be until the Webster-Ashburton Treaty of 1842 that the US Navy rejoined the international struggle against the slave trade in any meaningful way. ${ }^{121}$ While a disheartening reminder of the lack of political will, both domestically and internationally, toward stopping the slave trade, the case reflects contemporary US foreign policy goals in an era when the nation struggled to be viewed as a significant actor on the world stage. The incident, which coincided with the culmination of contentious negotiations with France, proved to be the manner by which the United States was able to assert its own autonomy in an international environment that continued to challenge its sovereignty. To the United States, the slave trade was thus the fulcrum with which it could balance itself between national and international priorities.

The years between 1808 and 1823, during which the United States negotiated the difficult landscape of European prioritization of the slave trade's suppression, coincided with a significant change in US foreign policy. As early republican fears of the union's impermanence faded and gave way to more stringent antebellum defenses of slavery, the United States debated the role it was to play in international politics, straddling the line between earnest and insincere actions against the international slave trade. When the USS Alligator seized the Jeune Eugénie, the United States briefly joined Europe as an enforcer against the inhuman traffic. Although the ship

\footnotetext{
${ }^{120}$ Gallatin to Adams, Paris, February 2, 1822, in Gallatin, Writings, 229.

${ }^{121}$ Oakes, Freedom National, 262; C. Herbert Gilliland, introduction to USS Constellation: On the Dismal Coast; Willie Leonard's Journal, 1859-1861, ed. C. Herbert Gilliland (Columbia: Univ. of South Carolina Press, 2013), 2.
} 
was certainly a slaver owned by American citizens, the US government encouraged the court to relinquish the ship to the French government to avoid any further challenges to its sovereignty. The case of the Jeune Eugénie thus exemplifies the US government's approach to the suppression of the slave trade prior to 1824, appearing to adhere to European priorities while maintaining its own sovereignty. In the terminology of Timothy Patrick McCarthy and John Stauffer, the Jeune Eugénie incident was the origin, no matter how unsteady, of the United States' dealings with the issue of slave-trade suppression. The executive branch had protected the independence of the federal judiciary, which, in their words, proved to provide the means to the slave trade's destruction. 


\section{CHAPTER II: THE MEANS AND ENDS: FREEDOM INTERNATIONAL?}

By the summer of 1772, thirty-one-year-old James Somerset had been enslaved most of his life. Purchased at age eight by Scottish-born Virginia merchant Charles Steuart in August 1749, Somerset had lived a relatively privileged life as an enslaved person. According to Steven M. Wise, he was said to have "enjoyed his master's affection" and, by adulthood, "had become Steuart's intimate, a trusted manservant, and, at times nearly his master's alter-ego." Steuart had lavished Somerset with "silks, stockings, and ribbon" and allowed him significant freedom to run errands in and out of his duties. Yet Somerset was still enslaved. ${ }^{122}$

When Somerset accompanied him to England in 1769, Steuart—by then the senior-most customs collector for British America — expected that the slave's years of loyal service would continue. But, in late 1771, Somerset ran away. On the run for fifty-six days, Somerset was eventually captured and, on Steuart's orders, placed aboard a ship bound for Jamaica, where he would be worked to death as punishment for his betrayal. Through the intervention of three unknown petitioners, however, a writ of habeas corpus was filed with Chief Justice William Murray, Lord Mansfield, of King's Bench. Somerset was temporarily released. He consulted with abolitionist Granville Sharp, while the court would consider whether Steuart had the right to decide his fate. ${ }^{123}$ Six months later, in June 1772, Mansfield's decision in the case disputed the legitimacy of slavery in the common law. "It is so odious that nothing can be suffered to support it but positive law," Mansfield declared. "Whatever inconveniences, therefore, may follow from a decision, I cannot say this case is allowed or approved by the law of England, and therefore the

\footnotetext{
${ }^{122}$ Steven M. Wise, Though the Heavens May Fall: The Landmark Trial That Led to the End of Human Slavery (Cambridge, MA: Da Capo Press, 2006), 1-6.

${ }^{123}$ Wise, Though the Heavens May Fall, 8-11.
} 
black must be discharged." Unless expressly provided for in municipal law, Mansfield held, slavery had no basis in the English legal tradition. ${ }^{124}$

The place of the slave trade in US law is a matter of historiographical debate. There is, importantly, consensus that Lord Mansfield's 1772 opinion in Somerset v. Stewart was the common law basis for legal abolition. ${ }^{125}$ It was this principle that asserted freedom to prevail in legal jurisdictions unless local legislation expressly provided for the condition of slavery. ${ }^{126}$ Scholars, however, disagree on how the decision manifested itself in the laws of the United States following the Revolution. While some have suggested that it had either limited effect on the early federal government's actions or led to the Constitution's proslavery provisions, ${ }^{127}$ others have accepted that, in the immediate aftermath of the Revolution, the decision influenced

${ }^{124}$ Capel Lofft, Reporter of Cases Adjudged in the Court of Kings Bench from Easter Term 12 George 3 to Michaelmas 14 George 3 (both inclusive) (1776), xvi, quoted in Wise, Though the Heavens May Fall, 182. ${ }^{125}$ See Wise, Though the Heavens May Fall, xvi; Robert H. Baker, Prigg v. Pennsylvania: Slavery, the Supreme Court, and the Ambivalent Constitution (Lawrence: Univ. Press of Kansas, 2012), 10; Robert M. Cover, Justice Accused: Antislavery and the Judicial Process (New Haven, CT: Yale Univ. Press, 1975), 16-17; Davis, Inhuman Bondage, 269; Andrew Delbanco, The War Before the War: Fugitive Slaves and the Struggle for America's Soul from the Revolution to the Civil War (New York: Penguin Books, 2018), 90; Seymour Drescher, Abolition: A History of Slavery and Antislavery (New York: Cambridge Univ. Press, 2009), 99-103; Paul Finkelman, An Imperfect Union: Slavery, Federalism, and Comity (Chapel Hill: Univ. of North Carolina Press, 1981), 16-17; Finkelman, Supreme Injustice: Slavery in the Nation's Highest Court (Cambridge, MA: Harvard Univ. Press, 2018), 16; Steven Lubet, Fugitive Justice: Runaways, Rescuers, and Slavery on Trial (Cambridge, MA: Belknap Press of Harvard Univ. Press, 2010), 17-18; Earl M. Maltz, Slavery and the Supreme Court, 1825-1861 (Lawrence: Univ. Press of Kansas, 2009), 83; James Oakes, Freedom National: The Destruction of Slavery in the United States (New York: W. W. Norton, 2014), ix, 9; Manisha Sinha, The Slave's Cause: A History of Abolition (New Haven, CT: Yale Univ. Press, 2016), 22; David Waldstreicher, Slavery's Constitution: From Revolution to Ratification (New York: Hill \& Wang, 2009), 41; John Fabian Witt, Lincoln's Code: The Laws of War in American History (New York: Free Press, 2012), 242. See also Derek A. Webb, “The Somerset Effect: Parsing Lord Mansfield's Words on Slavery in Nineteenth Century America," Law and History Review 32, no. 3 (August 2014): 457, https://www.jstor.org/stable/43670721; Justin Buckley Dyer, "Slavery and the Magna Carta in the Development of Anglo-American Constitutionalism," PS: Political Science and Politics 43, no. 3 (July 2010): 479, https://www.jstor.org/stable/25699354; George van Cleve, "Somerset's Case and Its Antecedents in Imperial Perspective," Law and History Review 24, no. 3 (Fall 2006): 606, https://www.jstor.org/stable/27641404.

${ }^{126}$ Oakes, Freedom National, 14.

${ }^{127}$ Baker, Prigg v. Pennsylvania, 23; Don E. Fehrenbacher, The Slaveholding Republic: An Account of United States Government's Relations to Slavery, ed. Ward M. McAfee (New York: Oxford Univ. Press, 2001), 102; Lumet, Fugitive Justice, 18; Waldstreicher, Slavery's Constitution, 41. Baker emphasized that Northern blacks, particularly in Massachusetts, had flooded the courts with freedom petitions prior to Somerset, suggesting that the decision simply coincided with Revolutionary notions of liberty, which would otherwise have led to gradual emancipation laws; Waldstreicher argued that the decision's potential to place slavery under Parliament's power "horrified" Benjamin Franklin and Thomas Jefferson. 
the Founders in their efforts to set the institution of slavery on its path to eventual destruction. ${ }^{128}$ Robert M. Cover, however, has asserted that the Somerset, or freedom, principle spurred both antislavery and proslavery efforts during the early national period. Its effect was multifaceted, undergirding states' gradual emancipation laws while simultaneously leading to the Fugitive Slave Clause's insertion in the Constitution. Without the insertion of the Fugitive Slave Clause in the Constitution, he asserted, prevailing notions of international reciprocity meant states would not recognize another state's enslaved property; as a result, slaves fleeing to free jurisdictions would otherwise have not been required to be returned. But he noted that, in instances where slaves fled to free jurisdictions, judges felt the need to word their decisions with incredible care and precision. Not to assert the principle during this time, he concluded, was considered to hold the potential to "universalize" slavery. ${ }^{129}$

Even among scholars who agree that the freedom principle manifested itself in the antislavery efforts of the Founders, there is a divergence of opinion on whether Somerset shaped US law once the constitutional system was well in place. Paul Finkelman has suggested that, after having guided the antislavery jurisprudence of the early republic, judges in Northern states deliberately abandoned the freedom principle for the sake of national union, only to recover it during the rise of radical abolitionism. ${ }^{130}$ James Oakes, on the other hand, has downplayed that there was any intentionality behind the apparent gap between the freedom principle's applications. His argument instead emphasizes that slavery had not yet, during this period, become the central issue of national politics. ${ }^{131}$ But both historians notably point to the same

\footnotetext{
${ }^{128}$ Delbanco, The War Before the War, 90-91; Finkelman, An Imperfect Union, 70; Oakes, Freedom National, 9-11.

${ }^{129}$ Cover, Justice Accused, 91.

${ }^{130}$ Finkelman, An Imperfect Union, 101.

${ }^{131}$ Oakes, Freedom National, 10-14.
} 
case, Commonwealth v. Aves, as a turning point toward the ultimate defeat of slavery in the United States. ${ }^{132}$

The question of the freedom principle's place in antebellum American law is not insignificant. How that idea affected jurisprudence during the era reveals the degree to which justice in the United States was the pawn of the Slave Power. It is, importantly, a matter of focus. It is the distinction between the interpretations of James Oakes and Don E. Fehrenbacher. Whereas Oakes' Freedom National tells of the rise of antislavery politics through the steady construction of legal precedents across the antebellum period, Fehrenbacher's The Slaveholding Republic emphasizes that these cases frequently failed. Where Oakes saw the steady barrage against slavery as the signs of its ultimate destruction and the ascension of a Republican party intent on abolition, Fehrenbacher depicted the legal arguments of antislavery advocates as rhetorical devices and the Republican party far from earnestly antislavery. In this light, Fehrenbacher could say without hesitation that the federal government, with its judiciary overtly proslavery, was under slavery's control. ${ }^{133}$ Without emphasizing the freedom principle, Fehrenbacher's interpretation lends itself not only to a portrait of a coopted, proslavery federal government, but a blurred distinction between federal and state sanctions of slavery. Focusing on the freedom principle means the difference between focusing on the decisions in which the judiciary tied the hands of the federal government against interfering with slavery and highlighting the long-term effort to build a legal basis for abolition, which, while often met with failure, was essential for emancipation to occur. Pointing to the slave trade, this chapter embraces Oakes' interpretation, expanding his argument to the international sphere.

\footnotetext{
${ }^{132}$ Finkelman, An Imperfect Union, 101; Oakes, Freedom National, 14.

133 Oakes, Freedom National, xii-xiii; Fehrenbacher, The Slaveholding Republic, 219, 245.
} 
The literature on court cases during the antebellum period has historically revolved around instances of domestic law. ${ }^{134}$ Viewing fugitive slave cases such as Prigg v. Pennsylvania and Dred Scott, historians have highlighted the highly constrained position in which the federal government could act in relation to domestic slavery. Finkelman, whose numerous works on law prior to the Civil War have primarily discussed fugitive slave cases, has shown that the decisions in these cases aligned with proslavery forces and has claimed support of slavery was an essential element of United States Supreme Court jurisprudence during the period. ${ }^{135}$ Even Oakes, in Freedom National, provides little discussion of the slave trade outside of the Amistad case, focusing heavily on the relationship of the freedom principle to fugitive slave cases. He has nevertheless alleged that the freedom principle could be applied abroad. ${ }^{136}$

The slave trade offers the opportunity to study the slavery question from a different perspective. Some scholars have, admittedly, carried their analyses of domestic cases to the slave trade while maintaining their arguments. Finkelman, for example, has argued that slave trade cases still reflect a pattern of proslavery jurisprudence, and he has emphasized that they had little effect on the state of slavery within the United States. ${ }^{137}$ Attempting to apply Fehrenbacher's broader argument to US slave-trade suppression, Sarah A. Batterson has suggested enforcement of US laws against the slave trade was never a federal priority, citing the US Navy's Africa Squadron as the clearest evidence of failure. ${ }^{138}$ But even Fehrenbacher admitted that there were periods in which the laws against the slave trade were effectively enforced, despite those suppression efforts being the made by the "slaveholding republic." 139 As Earl M. Maltz has

\footnotetext{
${ }^{134}$ See, for example, Delbanco, The War Before the War; Finkelman, An Imperfect Union; Lubet, Fugitive Justice.

${ }^{135}$ Finkelman, Supreme Injustice, 9.

${ }^{136}$ Oakes, Freedom National, 261.

${ }^{137}$ Finkelman, Supreme Injustice, 223.

${ }^{138}$ Fehrenbacher, The Slaveholding Republic, 148.

${ }^{139}$ Sarah A. Batterson, “'An Ill-Judged Piece of Business': The Failure of Slave Trade Suppression in a Slaveholding Republic” (PhD diss., Univ. of New Hampshire, 2013), 4, ProQuest ID 1436984189.
} 
importantly noted, the slave trade represented one of the few areas in which the federal government could control slavery, its authority coming directly from the Constitution. Certainly, he held, the fugitive slave cases that arose throughout the antebellum period shined a spotlight on the sectional crisis. Maltz has argued that US laws against the slave trade, regardless of their enforcement, were a clear antislavery commitment by the federal government and has rejected the idea that the Supreme Court was consistently proslavery until Dred Scott. ${ }^{140}$ An aspect of antislavery clearly prescribed by the Constitution, US laws against the slave trade complicate the image of a federal government entirely yielding to the Slave Power.

With radical abolitionism's rise in the 1830s, more traditional legally grounded abolitionism gave way to the moral appeals of immediatist lawyers. As legal scholar Robert M. Cover showed nearly fifty years ago, the fractured nature of the abolitionist movement "produced an impulse to use litigation as a dramatic forum for ideology." Courtrooms became the sites for dramatic spectacles where the plight of enslaved humanity was put on full display. ${ }^{141}$ Abolitionist attorneys meanwhile grew increasingly more ideological in their arguments, moving away from mere appeals to judges' generosity or pity, which had occasionally characterized the pleadings of traditional antislavery advocates, to assertions of uncompromising morality. "It is one thing," Cover wrote, "to be begged to act in a particular way by appeal to the presumed magnanimity of the man and the institution, quite another to be threatened with scorn and damnation for being a gutless sycophant."142 Although these cases predominantly dealt with fugitive slaves, there were instances in which these abolitionist attorneys used these techniques against the slave trade. ${ }^{143}$ Carrying forward Cover's argument, Jeannine Marie DeLombard has,

\footnotetext{
${ }^{140}$ Maltz, Slavery and the Supreme Court, ix-xx, 10-11.

${ }^{141}$ Cover, Justice Accused, 160 - 161.

${ }^{142}$ Cover, Justice Accused, 212 - 213.

${ }^{143}$ Cover, Justice Accused, 160-161.
} 
more recently, argued that, through their numerous publications, the abolitionists took their ideological battle being waged in the courtroom to the public. Abolitionists, she held, took advantage of a preexisting American culture of legal spectatorship. Using the trials of fugitive slaves as an integral part of their propaganda, abolitionists framed their struggle in terms relatable to a substantial portion of the reading public, thereby cultivating greater support. ${ }^{144}$

The trials in the Amistad case in many ways fit the framework of Cover and DeLombard. To those who saw them in the courtrooms of New London, the Amistad Africans, in Rediker's words, "performed slavery," highlighting the moral repugnance of slavery through their quintessentially human displays of emotion and suffering. ${ }^{145}$ The Africans were further exhibited in the abolitionist press; through interviews and treatments, their personalities were circulated to the press to garner financial support for their defense. ${ }^{146}$ The Amistad case, so significant in the American collective memory of the slave trade, represented the non-legal courtroom strategies of radical abolitionism.

In Freedom National, Oakes depicted antislavery advocates having slowly, over time, constructed and perfected a legal attack on slavery. This offers a framework through which the United States' slave trade cases may be viewed. Case after case, these antislavery lawyers chiseled away at the edifice of slavery. And, by the Civil War, their argument was strong enough to bring about the institution's destruction. ${ }^{147}$ In many ways, this argument recalls the form of Revolutionary-era abolitionism used by the Pennsylvania Abolition Society suggested in Richard S. Newman's The Transformation of American Abolitionism. Newman wrote, “A steady buildup

\footnotetext{
144 Jeannine Marie DeLombard, Slavery on Trial: Law, Abolitionism, and Print Culture (Chapel Hill: Univ. of North Carolina Press, 2007), 2-3.

145 Rediker, The Amistad Rebellion, 158.

146 Rediker, The Amistad Rebellion, 10-11.

147 Oakes, Freedom National, 4, 431.
} 
of narrow judicial victories, PAS strategists argued, would hamper slavery's operation as a national institution and compel even southern masters to support gradual abolition schemes." Although Newman distinguished this earlier form of abolitionism as not intending to challenge slavery's nationwide existence, that the antislavery lawyers of Oakes' narrative endeavored, through the freedom principle, to reiterate time and time again that slavery was purely a local institution reflects this Revolution-era strategy. ${ }^{148}$

That the US government routinely took slave traders to court, prosecuting them under the laws enacted by the founding generation, is a crucial element toward understanding the United States' journey to total emancipation. ${ }^{149}$ These trials honed federal law against the slave trade, priming the judiciary for the traffic's later destruction. This pursuit of slave-trade suppression through the judiciary represented the continuity and culmination of legalistic antislavery, which brought the United States closer to freedom on a nationwide scale. Using three vignettes, this chapter will show that the tactics of traditional, legalistic abolitionism manifested themselves in the admiralty proceedings against slavery. The forfeitures of slave ships provided the baseline for the slave trade's suppression, without which the freedom principle could not have been used with success. All that was needed was the right administration, intent on ensuring slave traders would not escape with impunity. For, without the slave trade's eradication, domestic abolition had little hope of permanence.

\section{"What Could Be Done with Honest Exertion and an Adequate Force"}

In early April 1820, the USS Cyane traveled south along the African coast toward the slave trading center of Cape Mount, at the mouth of the Gallinas River. The ship's presence off

\footnotetext{
${ }^{148}$ Richard S. Newman, The Transformation of American Abolitionism: Fighting Slavery in the Earlier Republic (Chapel Hill: Univ. of North Carolina Press, 2002), 61.

${ }^{149}$ For a list of cases found related to the slave-trade prosecutions, see Appendix A.
} 
African shores was part of a new, proactive approach to slave-trade suppression. A year earlier, the US Congress enacted another in a series of slave-trade laws, providing $\$ 100,000$ for the president to use the "armed vessels of the United States" for policing the international slave trade. Under the law, the US Navy was not only to patrol the coasts of the United States but those of Africa as well. This was a bold, unprecedented push by Congress. The United States appeared to commit itself to foreclosing the slave trade, and the Navy was given the means to do so. Quickly, however, debate in James Monroe's cabinet resulted in the targeting of the funds toward another, more indirect aspect of antislavery: colonization. Although the act's appropriation had undoubtedly been intended to go to the Navy, the American Colonization Society (ACS) found itself with freshly brimming coffers. An ACS agent on the ground in Africa would manage the funds, while the Navy would ensure colonists' safe conduct to the developing community. ${ }^{150}$ By December 1819 — two years before the Monroe administration would show its prioritization of national sovereignty over slave-trade suppression in the Jeune Eugénie casethe fifth president announced that his cabinet had begun making arrangements for a US warship to escort agents to Africa "in time to meet the delivery of any persons who might be taken by the

\footnotetext{
${ }^{150}$ Fehrenbacher, The Slaveholding Republic, 152-154.
} 
public vessels and landed there." ${ }^{151}$ The Cyane was that warship. ${ }^{152}$ Its 1820 patrol along the coast of Sierra Leone resulted in the first significant enforcement of US slave-trading laws. And its seizures established the legal precedent that admiralty forfeitures were the most reliable method of slave-trade suppression.

Much attention has been paid in the literature to the Supreme Court's 1825 decision in the case of the Antelope for its weak condemnation of the slave trade, which seemed implicitly to sanction the ship captain's conduct. A US revenue cutter had seized the vessel, allegedly the property of a Spanish citizen, off Florida in 1820, after it had been taken and for some time operated by pirates. ${ }^{153}$ Chief Justice John Marshall wrote the court's opinion. He highlighted that, although a growing number of countries had moved to abolish the slave trade, not all states had banned it. Because there was no international consensus on the trade's illegality, the traffic in Africans across the Atlantic was, he held, not contrary to the law of nations. Marshall nevertheless admitted that the trade went against the law of nature but asserted that it was not piracy. Because of this, he held that the right of search did not apply to the trade in peacetime

${ }^{151}$ James Monroe to Congress, December 17, 1819, in James D. Richardson, ed., A Compilation of the Messages and Papers of the Presidents, vol. 2 (New York: Bureau of National Literature, 1897), 633. Monroe wrote in a message to Congress on December 17, 1819, explaining his interpretation of the act. To him, the law supported executive implementation of colonization as a means of preventing the accumulation of illegally imported Africans in the United States. There was, therefore, no directly abolitionist character to the law. He wrote, "It is enjoined on the Executive to cause all negroes, mulattoes, or persons of color who may be taken under the act to be removed to Africa. It is the obvious import of the law that none of the persons thus taken should remain within the United States, and no place other than the coast of Africa being designated, their removal or delivery, whether carried from the United States or landed immediately from the vessels in which they were taken, was supposed to be confined to that coast. No settlement or station being specified, the whole coast was thought to be open for the selection of a proper place at which the persons thus taken should be delivered. The Executive is authorized to appoint one or more agents residing there to receive such persons, and $\$ 100,000$ are appropriated for the general purposes of the law." He concluded, "On due consideration of the several sections of the act, and of its humane policy, it was supposed to be the intention of Congress that all the persons above described who might be taken under it and landed in Africa should be aided in their return to their former homes, or in their establishment at or near the place where landed." James Monroe to Congress, December 17, 1819, in A Compilation of the Messages and Papers of the Presidents, 2:632-634.

${ }^{152}$ Fehrenbacher, The Slaveholding Republic, 154-155; Donald L. Canney, Africa Squadron: The U.S. Navy and the Slave Trade, 1842-1861 (Washington, DC: Potomac Books, 2006), 8-9.

153 The Antelope, 23 U.S. 66, 123-124 (1825). 
and that the vessel's seizure was unlawful. ${ }^{154} \mathrm{He}$ recognized and granted restitution for only a portion of the claims - specifically, those from Spanish, rather than Portuguese, claimants. ${ }^{155}$ Apparently rejecting Congress' suppression legislation passed only a few years earlier, Marshall's opinion stymied the enforcement of US law. His strange, divided method of restitution concerning the enslaved cargo, moreover, has been suggested to have been an indication of his support of the slave trade. ${ }^{156}$ In the literature, the Antelope decision has emerged as the preeminent antebellum slave-trade case until the Supreme Court's Amistad decision of 1841, standing in glaring opposition to any suggestion of a United States committed to the slave trade's suppression. Although federal prosecutions of slave ships admittedly diminished after the Antelope case, to focus on Marshall's decision, however, ignores the significant volume of slaveship forfeitures upheld by the courts during the 1820s, a trend that began with the Cyane's 1820 voyage. ${ }^{157}$

Having been delayed for some time with heavy harbor ice, the Cyane left New York in February 1820 under the command of Captain Edward Trenchard. ${ }^{158}$ The ship, captured from the British off Madeira by the USS Constitution in $1815,{ }^{159}$ accompanied a merchant brig bearing

\footnotetext{
154 The Antelope, 23 U.S. at 119-124. For book-length studies of the Antelope affair, see Jonathan M. Bryant, Dark Places of the Earth: The Voyage of the Slave Ship Antelope (New York: Liveright, 2015); John T. Noonan Jr., The Ordeal of Recaptured Africans in the Administrations of James Monroe and John Quincy Adams (Berkeley: Univ. of California Press, 1977). Also, for the case's relationship to the repatriation of the Antelope's enslaved Africans, see Sharla M. Fett, Recaptured Africans: Surviving Slave Ships, Detention, and Dislocation in the Final Years of the Slave Trade (Chapel Hill: Univ. of North Carolina Press, 2017), 26-29.

${ }^{155}$ The Antelope, 23 U.S. at 132-133.

${ }^{156}$ For historians who have articulated this view of the decision, see Finkelman, Supreme Injustice, 90-102; Maltz, Slavery and the Supreme Court, 4-11; Cover, Justice Accused, 102-104; Fehrenbacher, The Slaveholding Republic, 192-193; Sinha, The Slave's Cause, 409.

${ }^{157}$ In addition to the cases cited below that arose from the Cyane's patrols, see The Alexander, 1 F. Cas. 362 (C.C.D.Mass. 1823); The Emily, 22 U.S. 381, 389 (1824); The Merino, 22 U.S. 391, 392-394 (1824); The St. Jago de Cuba, 22 U.S. 409, 410-411 (1824).

${ }^{158}$ Earl E. McNeilly, "The United States Navy and the Suppression of the West African Slave Trade, 1819-1862" (PhD diss., Case Western Reserve Univ., 1973), 43, ProQuest ID 302637917; Fehrenbacher, The Slaveholding Republic, 154; Canney, The Africa Squadron, 9.

159 Theodore Roosevelt, The Naval War of 1812 (1882; New York: Modern Library, 1999), 230-232; Canney, Africa Squadron, 9.
} 
nearly ninety African Americans and ACS agents across the Atlantic to Sherbro Island, Sierra

Leone. ${ }^{160}$ The pair arrived in mid-March $1820 .{ }^{161}$ Depositing the colonists on the island,

Trenchard assigned a midshipman and some of the Cyane's crew to help them settle in.

Trenchard and the Cyane traveled south to scout out a more hospitable location for a permanent settlement. ${ }^{162}$ It was on this surveying mission that, on the morning of April 5, 1820, Trenchard spotted fourteen ships anchored at the mouth of the Gallinas, likely waiting to receive enslaved cargoes. ${ }^{163}$

As soon as the slave ships saw the Cyane bearing down on them, they each tried to make sail. The water was calm; the wind was sparse. Knowing that the ships had little chance of escape, Trenchard ordered each of the Cyane's boats to stop them. On one boat was the Cyane's first officer, Lieutenant Silas H. Stringham, who pursued the Science. ${ }^{164}$ Once the twenty-one-

\footnotetext{
${ }^{160}$ Fehrenbacher, The Slaveholding Republic, 154; Canney, The Africa Squadron, 9; McNeilly, "The United States Navy and the Suppression of the West African Slave Trade," 43-46. There seems to be some debate over the number of African American émigrés aboard the Elizabeth. Canney claimed that there were eighty-eight, whereas Fehrenbacher and Rees counted eighty-six. It should also be noted here that Canney's work, while arguably a trade publication that synthesized several treatments on this early naval effort against the slave trade, took some liberties in using the information presented by Fehrenbacher and McNeilly, with phrasing frequently coming awfully close to these earlier sources. It nevertheless is an easily obtainable starting source for research into US naval slave-trade suppression but should be taken with caution.

${ }^{161}$ Siân Rees, Sweet Water and Bitter: The Ships That Stopped the Slave Trade (Durham: Univ. of New Hampshire Press, 2011), 66. "Extract of a Letter from a Midshipman on Board the United States' Ship Cyane, Dated Sierra Leone, March 23d, 1820," Maryland Gazette (Annapolis, MD), June 1, 1820; “The Ship Elizabeth, Capt. Sebor, Which Sailed from This Port, in February Last, for Africa, Has Arrived at Turk's Island," National Intelligencer, June 3, 1820. The Cyane reached Freetown, Sierra Leone, on March 23, 1820, after a six-week transatlantic voyage. The Elizabeth arrived on March 9 and had, by the Cyane's arrival, already traveled to Sherbro Island, which it made on April 19.

162 McNeilly, "The United States Navy and the Suppression of the West African Slave Trade," 45-46; Canney, The Africa Squadron, 9.

${ }^{163}$ United States v. Malebran, 26 F. Cas. 1145 (C.C.S.D.N.Y. 1820); Edward Trenchard to unknown recipient, April 10, 1820, in A View of the Present State of the African Slave Trade (Philadelphia, 1824), 33-34, https://lccn.loc.gov/18018090; United States v. Andrews, 24 F. Cas. 815, 816 (C.C.S.D.N.Y. 1820); Trenchard, April 10, 1820, in A View of the Present State of the African Slave Trade, 33. McNeilly placed the ambush of a "large fleet" of slave ships on April 10, 1820. According to the court report of one of the cases, Stringham testified that he boarded at least one of the ships on April 6, 1820. This date corresponds with the published report that Captain Trenchard submitted after the seizures. He noted that the Cyane encountered fourteen ships on the morning of April 5, 1820.

${ }^{164}$ Stringham was born in either 1797 or 1798 . He joined the Navy as a midshipman in 1809 and was made a lieutenant in December 1814, at the age of sixteen. He served on the USS President during the Little Belt Affair of 1811 and was a veteran of the War of 1812, serving in engagements with the HMS Belvidera. He served through the
} 
year-old lieutenant reached the ship, it took only moments for him to reach a conclusion on its slaving character. Along with "muskets, tobacco, and calicoes, the usual cargo for the slave trade," Stringham found fifty pairs of irons but no slaves. But Stringham also found documents implicating several men in the Science's slaving voyage, a Cuban resident of New York named Eugene Malebran, the Science's captain Adolphus La Coste, and a man called Francisco Mathieu. ${ }^{165}$ Among those documents were letters, written in French, from Malebran to Mathieu and La Coste, but, as Stringham later testified, the letter to La Coste bore clear instructions on how the captain was to acquire slaves. The letter directed "him to proceed to Porto Rico, where the vessel was to be changed into Spanish; and after procuring shackles, handcuffs, etc., to proceed on the contemplated voyage. Another person, at Porto Rico, was to assume command of the vessel. He was to be the captain on paper; but La Cost, the real captain ... was to receive further directions from the brother of the defendant" in Cuba. In Cuba, La Coste would deposit the slaves, referred to in the letters as "merchandise," and, in exchange, be paid based on the number of Africans he delivered. Stringham noted that "the word 'slaves' was not mentioned." Convinced that the Science was a slaver, Stringham seized the ship under the 1818 Slave Trade Act for having been outfitted for the trade in the United States. ${ }^{166}$

\footnotetext{
Mexican War to the Civil War, leading the naval attack on the batteries of Hatteras Inlet before retiring to port duties in 1862. Appleton's Cyclopcedia of American Biography, rev. ed., vol. 5 (1898), s.v. "Stringham, Silas Horton"; American National Biography, s.v. "Stringham, Silas Horton," by John B. Hattendorf and Patrick G. Williams, accessed February 1, 2021, https://doi-org.libproxy.lib.ilstu.edu/10.1093/anb/9780198606697.article.0400963. ${ }^{165}$ Malebran's first name is provided in an article on his attorney, Thomas Addis Emmett, published in the nowdefunct New York State Historical Association's journal in 2014. Craig A. Landy, "Society of United Irishmen Revolutionary and New-York Manumission Society Lawyer: Thomas Addis Emmett and the Irish Contributions to the Antislavery Movement in New York," New York History 95, no. 2 (Spring 2014): 215, https://www.jstor.org/stable/newyorkhist.95.2.193. For purposes of consistency, the present study uses "Adolphe La Coste" as the form of the name for the Science's captain. In secondary and primary sources, his first name is variably written as "Adolphus" and "Adolph," and his last name is put as "La Coste" and "Lacoste," among others. "Adolphe La Coste" is the form used in Justice Story's opinion in his appeal. United States v. La Coste, 26 F. Cas. 826 (C.C.D.Mass. 1820).

${ }^{166}$ Malebran, 26 F. Cas. at 1146. Archaic spelling of "Puerto Rico" as well as misspelling of "La Coste" are in original. It should be noted, too, that Trenchard's April 10, 1820, letter does not list the Science as one of the ships seized on April 5. Listed are the sail schooners Dasher and Eliza, the brig La Anita, and the topsail schooners
} 
Stringham also inspected the Endymion, anchored nearby. There, the lieutenant found a similar state of readiness, bearing all the necessary equipment for the Middle Passage. The captain, Alexander McKim Andrews, who had been pulled from a small boat frantically paddling for the shore, was, Stringham learned, a citizen of Baltimore and a US Navy midshipman on furlough. ${ }^{167}$ The search yielded an American register, a berth deck, a large quantity of water, two large cabooses — or kitchens — and plenty of provisions. Testifying before the federal circuit court in New York, Stringham recalled that the ship "had every appearance of a vessel engaged in the slave trade." The court report noted that this was "equipment of which the witness was well acquainted," including a "large quantity" of handcuffs. The Endymion had not yet taken on slaves, but that did not make it any less of a slave ship. When Andrews admitted that he and his vessel were American, the Cyane seized its prize. ${ }^{168}$

The Cyane also seized the Plattsburgh. Unlike the Science and the Endymion, however, the Plattsburgh's national origin was unclear. It bore all the signs of a slaver, with barrels of handcuffs and 300 kegs of gunpowder, along with grape, canister, and round shot being found aboard. But it was allegedly owned by Spanish citizens. Registered as an American vessel in Baltimore in 1817, the Plattsburgh had been owned by American citizens Thomas Sheppard, John N. D'Arcy, and Henry Didier. When it left the port of Baltimore in December 1819, the ship was also under the command of an American citizen, Joseph F. Smith. It arrived in

\footnotetext{
Lorise, Esperanza, and Endymion. It is more than likely that the Science and the Plattsburgh, discussed later on, were seized on the same date. This is, moreover, the narrative told in McNeilly. McNeilly, "The United States Navy and the Suppression of the West African Slave Trade," 46-47. Malebran's letters were published in the National Intelligencer on November 17, 1820. "The Detestable Slave Trade," National Intelligencer, November 17, 1820. ${ }^{167}$ Trenchard, April 10, 1820, in A View of the Present State of the African Slave Trade, 33; Landy, "Society of United Irishmen Revolutionary and New-York Manumission Society Lawyer," 215.

${ }^{168}$ Andrews, 24 F. Cas. at 816.
} 
Santiago, Cuba—despite officially having left Baltimore for St. Thomas—where Sheppard, D’Arcy, and Didier sold the ship to George Stark for $\$ 12,500 .{ }^{169}$

The Plattsburgh's buyer, Stark, also owned the brig Eros, which had been in the port of Baltimore at the same time as the Plattsburgh. The Eros had been outfitted at Baltimore for the slave trade. When it departed the port soon after the Plattsburgh, it was briefly detained by port authorities on suspicion of being a slaver, but the port's collector "being satisfied, upon inquiry, that the owner of the Eros had no intention of having her engaged in the slave trade, afterwards released her, taking out some few of her equipments." According to some witnesses, the Plattsburgh, having cleared the port of Baltimore without any suspicion of being a slaver, collected the manacles and cannon shot needed for a trip to Africa further down the Chesapeake Bay. Waiting there, at New Point Comfort, ten to twelve days, the Plattsburgh rendezvoused with the Eros, took on Stark, and sailed together for Santiago. ${ }^{170}$

Arriving in Santiago, the Plattsburgh became a Spanish vessel through a straw sale. Sold again, this time to a Cuban named Juan Marino, for $\$ 8,000$, the ship was further altered for the slave trade. Given Spanish documents, its name was changed to the Maria Gertrudes. Part of these alterations included the onloading of the kegs of gunpowder that the crew of the Cyane later noticed, which had been transferred from the Eros to the Plattsburgh. The Plattsburgh's original crew was mostly discharged, except for the captain, two mates, six to eight men, and Stark. These men remained aboard during the Plattsburgh's journey to Africa—despite the ship

169 The Plattsburgh, 23 U.S. 133, 135-138 (1825). The first names of the owners are found in an article published for the legal history forum at the University of Maryland's Carey School of Law from 2013 by David Seaton. David Seaton, "Warts and All: How The Plattsburgh Should Change the Way We Look at the Face of Baltimore Maritime History," Legal History Collections (2013): 4-5, https://digitalcommons.law.umaryland.edu/cgi/viewcontent.cgi?article=1044\&context=mlh_pubs.

${ }^{170}$ The Plattsburgh, 23 U.S. at 135-138. 
being under the "nominal" command of a Cuban named Gonzalez — and were aboard when the ship was captured by Stringham and the Cyane. ${ }^{171}$

Although the Plattsburgh flew the Spanish flag, the Cyane's seizure proved justified. Upon his return to the United States, Stringham entered a letter into evidence that left little doubt as to the Plattsburgh's true ownership. Smith and the other Americans were, the letter suggested, the true orchestrators of the slaving voyage. "Sir, I wish you to get the schooner down to Moro in the morning," the letter read. "And get the men quartered to the guns, and station them on the tops and forecastle, the same as on board armed ships, and get all ready for going to sea tomorrow night. After you get down to the Moro, send the boat, with four men, for me." The letter was signed "Yours, Jos. Smith." This, coupled with the fact that the logbook was kept in English and that, as Stringham and others of the Cyane observed, the crew and even supposed captain of the Plattsburgh seemed deferential to Smith and Stark, was evidence enough that the ship was an American-led slaver. ${ }^{172}$

The following morning, the officers of the Cyane gathered to ensure that the ships could be claimed as prizes. All told, the Cyane had captured six ships. The investigation concluded that four were American slavers. As for the other two, Trenchard reported: "not exhibiting sufficient marks to identify them, I did not think proper to detain." ${ }^{173}$ In his unpublished 1973 dissertation on the US Navy's efforts at slave-trade suppression from 1819 to 1862, Earl E. McNeilly noted that "Although no slaves were found on board the American owned vessels, they were obviously equipped for the trade and sent off under prize crews for trial in New York." The number of ships that he calculated differs from the record. However, he continued, "Of the remaining

\footnotetext{
${ }^{171}$ The Plattsburgh, 23 U.S. at 138.

172 The Plattsburgh, 23 U.S. at 140-145.

${ }^{173}$ Trenchard, April 10, 1820, in A View of the Present State of the African Slave Trade, 33.
} 
captures, the nationality of three was so hopelessly confused that they were simply destroyed

with the excuse that they were unseaworthy, and the slaves which they had already embarked

were landed at Sierra Leone." As for their arrival in New York, McNeilly wrote that "There is no

record ... that any of these prisoners were ever tried under federal anti-slavery legislation." 174

The "remaining" ships to which McNeilly referred is unclear. Trenchard's April 10, 1820, letter

failed to mention this detail. What is known, however, is that Stringham was appointed the prize

master of the Cyane's captures and led them, together, back to the United States, ${ }^{175}$ and, most

importantly, the prisoners were, contrary to McNeilly's claim, put on trial. ${ }^{176}$

The three schooners arrived in New York over the evening of May 26-27, $1820 .{ }^{177}$ The

thirteen prisoners of the Science, Endymion, and Plattsburgh arrived in Boston on July 6, 1820,

${ }^{174}$ McNeilly, "The United States Navy and the Suppression of the West African Slave Trade," 47; Canney, Africa Squadron, 9. It appears that Canney unquestioningly repeats McNeilly's claims.

175 "Original Document: Extract from Journal of the U.S.S. Cyane, 1820," Magazine of American History: A Monthly Illustrated Journal 30, no. 1-2 (July-August 1893): 92-95, https://books.google.com/books?id=U5o_AQAAMAAJ\&pg=PT2\#v=onepage\&q\&f=false. The Magazine of American History reprinted several entries from Captain Trenchard's logbook from April 5 to April 10, 1820, in its July 1893 issue. Among those entries are Trenchard's account of the initial seizures, his orders the following day to the Cyane's officers to inspect the seized vessels, and those officers' subsequent report. According to that report, Lieutenants Matthew C. Perry and Stringham, along with two midshipmen, the ship's master, and the ship's coastal pilot were completely convinced that the four ships were slavers. As to the Endymion, on April 6, they wrote, "Upon a close scrutiny we are of the opinion that the sole object of her being in this place is the procuring of slaves: indeed we have good evidence that she has her cargo of slaves nearly completed, and that they are now confined in irons at a town near the river, called Seymoboe. She is completely fitted for the accommodation of slaves, has on board several thousand gallons of water, and a very large quantity of rice, the common food of Negroes." They continued explaining their findings of the other vessels: "We have also examined the other vessels embraced in your order, and find that they are all deeply engaged in the traffic of slaves. There is but one, however, of those under foreign flags that we can ascertain is acting in contravention to the above law ... the schooner Esperanza (formerly the U.S. Revenue Cutter Alert) now under Spanish colors. She sailed last from Charleston, S.C., without a clearance ... the majority part of her crew who were American citizens." As for the Science and Plattsburgh, "We find that the Dechosa, or Science of New York, is owned by E. Mallebran of New York ... There is little doubt of her being American property, and consequently we are of opinion that she is violating the laws of the United States. We can only learn that the Maria Gatthreust or Plattsburg of Baltimore sailed from Baltimore ... and proceeded to this coast in quest of slaves. The number of her men and her strong armament induces us to believe that she is not only a vessel engaged in the traffic of slaves, but she is fully prepared to commit piratical aggressions on the flag of any nation." An extract of a April 10 letter by an anonymous officer of the Cyane, presumably Trenchard, was also published in the National Intelligencer on June 19, 1820. See "Of the Coast of Africa," National Intelligencer, June $19,1820$.

${ }^{176}$ Malebran, 26 F. Cas. 1145; Andrews, 24 F. Cas. 815; La Coste, 26 F. Cas. 826.

177 "Suppression of the Slave Trade," National Intelligencer (Washington, DC), May 30, 1820. 
transported separately via the brig Rebecca. ${ }^{178} \mathrm{~A}$ week later, these prisoners were brought before Judge John Davis at the US District Court for Massachusetts. The judge examined each of the prisoners, trying to determine their nationality as well as the extent of their culpability. As the Boston Daily Advertiser reported, "The prisoners appeared to be principally foreigners, of almost all nations, and shades of complexion." In addition to the eight known Americans, there were a Dane, a Prussian, natives of Southeast Asia and the Caribbean, and one man who claimed to have simply been born at sea. Two of the men, in fact, were black. One of them, John Thomas, was quoted as having told the judge that he had not asked about the nature of the voyage before he signed onto the crew: "He did not know ... about the object of the voyage, he shipped only as a seamen [sic] before the mast and 'studied only what wages he was to have." Sympathizing with the uninformed sailors, the article declared that "We have seen complaints made that the punishment of this class of offences should fall upon the ignorant agents, instead of the more guilty contrivers and instigators of the crime ... It is necessary for the security of society, that they should be held responsible who are guilty of the overt act." With evidence still to be provided, Davis decided that they should remain in custody until their trials and set bail for the sailors at $\$ 3,000$ and, for the ships' masters, $\$ 6,000 .{ }^{179}$

\footnotetext{
178 “The Brig Rebecca, Which Arrived Yesterday from the Cape de Verds, Brought in 13 Persons Who Had Belonged to Two Vessels Sent to New York on a Charge of Being Concerned with the Slave Trade," National Advocate (New York), July 10, 1820.

${ }^{179}$ Boston Daily Advertiser, "On Thursday Last the Brig Rebecca, Capt. Snow, Arrived from the Cape de Verde Islands," National Advocate (New York), July 11, 1820. For another, less detailed news report, see "The Persons Charged with Being Engaged in the Slave Trade," National Advocate, July 11, 1820. Rebecca was under the command of a Midshipman Valette. The prisoners were listed as: Captain Joseph Smith, Seamen John Lewis, John Vogle, John Thomas, James Williams, William Smith, George Pager, Peter Johnson, Antonio Bonifacie, John Delacruiz, Domingo Ambrosio, Francis Fernandez, Joseph Martino (of the Plattsburgh); Captain Adolphus Lacoste, Seamen Emanuel Fernandez, Antonio, Conzalez, Joseph J. King, and Kemp Southcomb (of the Science). There were, apparently, also "several" prisoners who were brought back to New York on the Science. Justice Henry Brockhurst Livingston had at least one hearing on an indictment for those men. He discharged the prisoners who showed themselves to be foreign citizens, as they were exempt from the slave-trade laws. "Some Days Since Were Brought Before Mr. Justice Livingston, Several Persons Who Had Been Taken by the Sloop of War Cyane," National Advocate, June 10, 1820.
} 
Federal prosecutors in New York and Boston in fact did go after the "instigators of the crime." The first case to go to trial was that of the Science's owner, Eugene Malebran, in September 1820. The Cuban resident of New York was indicted there on twenty-eight counts under the Slave Trade Act of 1818 for having prepared the ship for the slave trade within the waters of the United States. In those twenty-eight counts, however, the prosecution had failed to state the locations from which the Science had intended to procure and deliver its cargo. US Attorney Robert Livingston Tillotson called his witnesses one by one, including Lieutenant Stringham, who testified to the Science's slaving character. ${ }^{180}$

Once Tillotson rested the case for the prosecution, Malebran's attorney, Irish immigrant Thomas Addis Emmet addressed the bench. Despite being an active abolitionist, heavily involved with the New-York Manumission Society, Emmet believed that it was his "professional duty to provide a defense" for his client, regardless of the charge. He thus raised an objection to the indictment. "It appears from the proof," Emmet said, "that the place where they [the enslaved cargo] were to be procured was at Cape Mount, on the coast of Africa, and that to which they were to be transported was Trinity De Cuba. Both these places must, therefore, have been known to the grand jury; and therefore the indictment cannot be maintained." The evidence to which he referred were Malebran's letters, which Stringham had recovered from the Science months earlier, that provided specific instructions for the ship's journey. He continued, "There is no principle in criminal law better settled than this, that if a person is indicted for stealing goods of a person to the jurors unknown, and it appears, in proof, upon due inquiry, might have been known, that the indictment cannot be supported." The judge agreed and counselled the jury to

\footnotetext{
${ }^{180}$ Malebran, 26 F. Cas. at 1145-1147. The indictment originally listed the ship's port of origin, destination, and place of seizure in the traditional form of "to the jurors unknown," despite the prosecution's knowledge of those locations.
} 
acquit Malebran. At the prosecution's insistence, the defendant was held over for retrial during the following term, although this appears never to have come to fruition. The United States' first prosecution of a slave trader following its commitment to the trade's suppression had failed on a technicality. ${ }^{181}$ Malebran's trial had shown that even sustaining an indictment against an accused slave trader would be difficult.

Alexander McKim Andrews, captain of the Endymion, was also tried in New York in September 1820. Prosecutors, armed with an abundance of evidence, indicted the Navy midshipman and Baltimore native under the 1800 Slave Trade Act for intending to transport enslaved Africans between foreign countries. Lieutenant Stringham was again called to testify. In addition to finding equipment common to the slave trade aboard the Endymion, Stringham recalled to the court clear admissions of guilt that Andrews had made upon his ship's seizure. Andrews had first admitted, according to Stringham, that the Endymion was the Cyane's lawful prize, a confession that implicitly admitted participation in the slave trade. ${ }^{182}$

But Andrews' tendency to brag also revealed the lucrative nature of the slave trade.

Despite having been captured, Andrews had claimed to have already guaranteed the transportation of 150 enslaved persons by way of another ship. The sale of those Africans, alone,

\footnotetext{
${ }^{181}$ Malebran, 26 F. Cas. at 1145-1147. For a news report of the trial, see "Law Intelligence," National Intelligencer, September 27, 1820. This trial was also referenced in regard to Thomas Addis Emmet in Landy, "Society of United Irishmen Revolutionary and New-York Manumission Society Lawyer," 215-216. It is likely that Malebran was never retried. A report of ships arriving to the port of New York in early December 1820 lists a "E. Mallibran" as the recipient of cargo from the schooner Rover. Presumably, Malebran was therefore able to continue his work as a merchant. "Port of New-York," National Advocate, December 8, 1820. It is curious, too, to note Emmet's involvement with the New-York Manumission Society. Landy pointed to the case of William S. Smith, whom Emmet defended in 1806 for attempting a military invasion of Venezuela, as evidence of Emmet's belief in an attorney's professional responsibility. When questioned in that case if his political leanings might prevent his ability to conduct a defense, Emmet "assured the court that his motive in providing a defense was purely professional, pointing out that his personal affiliation with the Republican Party would not prevent the zealous representation of his client, stating "no sentiment of private respect or public feeling can be permitted to interfere with the discharge of my professional duty." Landy, "Society of United Irishmen Revolutionary and New-York Manumission Society Lawyer," $217 \mathrm{n} 87$.

${ }^{182}$ Andrews, 24 F. Cas. at 816. For a news report of the trial, see "Circuit Court of the U.S.: United States vs. Alex. McKim Andrews; Indictment for Being Concerned in the Slave Trade," National Advocate, September 19, 1820.
} 
meant that Andrews could pay back the Endymion's owners for the loss of the ship. But Andrews noted that the Endymion's loss was far from insignificant, for, had it not been captured, Andrews would have earned $\$ 200,000$ in addition to his wages of $\$ 200$ per month. At a time when the average merchant seaman made $\$ 15$ per month, Andrews boasted, he paid his sailors $\$ 40$. Adding to these mindboggling figures, testimony from a Dr. Wiley, an acquaintance of Andrews, suggested that the defendant had made it well known around his hometown of Baltimore that he would have paid $\$ 2,000$ to any attorney who could "free him from his embarrassment." 183 Although an enormous financial loss to the Endymion's owners, Andrews remained financially unscathed and had ensured his bosses would recoup their losses.

Also represented by Emmet, Andrews, like Malebran, not only had the benefit of shrewd legal counsel but also pure luck. Emmet argued that the statute on which the indictment was based was only intended to prevent sailors from serving on slave ships and that this prohibition did not apply to ship captains. Pointing to the provisions of the recent 1819 act, the prosecution argued that the position "contended for by the opposite counsel would render its provisions nugatory." The judge concurred, finding that even a ship's captain served for its owners and, therefore, was subject to the act. The trial concluded, and the jury deliberated. But, when it came time for the jurors to deliver their verdict, just eleven appeared. The court learned that "one of them on his way to the court had fallen down in a fit" and was incapable of attesting to his decision. Although the judge decided to remand Andrews for another trial, no retrial appears to have ever taken place. One New York juror's unfortunate — and incredibly untimely—seizure

\footnotetext{
${ }^{183}$ Andrews, 24 F. Cas. at 816-817.
} 
thus meant a slave trader's escape from justice. ${ }^{184}$ It was quickly becoming apparent that evidence alone would not be enough to convict an individual slave trader.

There seemed, however, to be redemption not long after Andrews' case was dismissed. Two of Malebran's sister cases, United States v. La Coste and United States v. Smith, went before the US Circuit Court for the Massachusetts district beginning on Thursday, November 9, 1820. Adolphus La Coste, the Science's captain, and Joseph F. Smith, captain of the Plattsburgh, were indicted under the 1818 Slave Trade Act for having sailed from New York intending to "procure" Africans to be "held, sold and disposed of as slaves." When the trial ended on the evening of Saturday, November 11, the jury briefly deliberated and returned a guilty verdict. ${ }^{185}$

Both defendants appealed their convictions. La Coste asked for a retrial, contending that, if any crime had been committed, it fell within the jurisdiction of the New York district, as the Science had been outfitted in the port of New York. Smith, having sailed the Plattsburgh from Baltimore, used a similar argument, replacing the suggested jurisdiction within that of the District of Maryland. Coupled with what they claimed were ambiguities in their original indictments, both La Coste and Smith also asked for his sentence to be postponed. "We have heard nothing that has induced us to change our opinion," Justice Joseph Story wrote in the $L a$ Coste case. "If the crime was not committed within the port of New York, but only by sailing out of the port, which was contiguous to the high seas, there was nothing which could prejudice the defendant in the omission." The ambiguities, too, were immaterial. The convictions of La Coste and Smith were upheld, ${ }^{186}$ and the two slave traders were sentenced to five years'

\footnotetext{
${ }^{184}$ Andrews, 24 F. Cas. at 816-817. Juror's seizure was reiterated in Landy, "Society of United Irishmen Revolutionary and New-York Manumission Society Lawyer," 215.

185 Boston Daily Advertiser, "Slave Trade," National Intelligencer (Washington, DC), November 15, 1820.

${ }^{186}$ La Coste, 26 F. Cas. at 826-831; United States v. Smith, 27 F. Cas. 1167, 1167-1170 (C.C.D.Mass. 1820).
} 
imprisonment. ${ }^{187}$ Despite the subsequent setbacks of the Jeune Eugénie affair, apparatuses of the US government - the US Navy and the federal court system — had shown themselves willing to take slave traders to court to enforce its anti-slave-trade laws and had won. Its commitment to slave-trade suppression was enshrined in legal precedent.

But the lessons of the final case involving the Cyane's seizures offered an even more effective strategy for combatting the trade. In 1825, the Supreme Court heard the claim of Juan Marino in the case of The Plattsburgh. Although not a criminal case under the Slave Trade Acts, the US Supreme Court was asked to decide how the US government was to handle forfeitures in slave-trading cases. As prize master, Lieutenant Stringham was responsible for ensuring that the Plattsburgh be rendered the Cyane's prize on his arrival with the ship in New York. He filed a libel of information with the District Court of New York, requesting that the Plattsburgh be condemned and forfeited. Stringham's libel asserted the Cyane's right to the ship as prize under the act of 1794, for having been outfitted for the slave trade within the jurisdiction of the United States, and under the act of 1800, for being an American-owned vessel engaged in the slave trade. The US District Attorney for New York subsequently condemned the ship under those acts, and the circuit court affirmed the condemnation. Marino, the Cuban to whom George Stark

\footnotetext{
187 “The Slave Trade," Niles' Weekly Register 10, no. 2 (April 20, 1822): 114. President Monroe pardoned an “A. Lacoste" in 1822, who was identified as having been convicted in Boston in 1820. Likely this was the Adolphus La Coste of the Science as the Niles' Weekly Register reported at that time that he was from Charleston, South Carolina, and had been sentenced to five years' imprisonment along with a $\$ 3,000$ fine. The article noted that the president justified the pardon in that "Lacoste, at the time of his conviction was only nineteen years of age - that his conduct, in other respects, had been exemplary, contributing largely to the support of his aged mother and sisters - that the punishment he had undergone had impaired his health, and that he often expressed his contrition for having been engaged in the detestable traffic." It continued, referencing the capital punishment that had been instituted with the 1820 act: "the release of the prisoner from the milder operation of the former law, affords reason to believe that Mr. Monroe will not feel disposed to execute the latter one, and punish with death those who may be found guilty of having violated it. It would be unfortunate, indeed, if this impression should go abroad, for it may encourage fresh adventurers in the murderous traffic: a traffic not only execrable from the amount of human life destroyed in carrying it on, but for the reason that it increases the amount of human misery, which will be avenged as surely as it is appointed for all men once to die. If there is any offence that is deserving of death, it is that of being engaged in the slave trade."
} 
allegedly sold the ship in 1820 prior to its journey to Africa, appealed the forfeiture, claiming he was the Plattsburgh's rightful owner. Coming before the Supreme Court, the appeal revolved around whether the ship's journey had begun in the United States or under Marino's auspices, after the purported sale in Cuba. If Marino orchestrated the voyage, the ship would not have been liable to forfeiture, as he was a Spanish citizen. ${ }^{188}$

After the parties presented their oral arguments on March 8 and 9, Justice Story delivered the court's opinion on March 14, 1825. He viewed the Plattsburgh's sale with suspicion. As he had learned in the case of the Jeune Eugénie, over which he had presided at the circuit court for the Massachusetts district in 1822, bills of sale could not be given face value in cases involving alleged slave ships. Despite the recorded testimony of the ship's former owners attesting to the sale, Story understood the thinking of American citizens hoping to engage in the trade. "Certainly the Court have nothing to do with the conscience of the Spanish claimant, if he has established a bona fide, legal ownership," he admitted. "But that is the very point in controversy. This is not the case of an ordinary trade, where no disguise is necessary or useful. It is the case of a trade prohibited to American citizens under very heavy penalties, penalties which have since been aggravated to the infliction of capital punishment." He carefully spelled out the increasingly common practice among US citizens intending to engage in the trade: "If carried on at all, it must, therefore, be carried on by Americans, under the disguise of foreign flags; and, it is notorious, that in the colonial ports of Spain, there is little difficulty in procuring all the apparatus for the use of the national flag." Story argued that there was reason to suspect that the Plattsburgh's sale had been feigned as a form of deception. ${ }^{189}$

\footnotetext{
188 The Plattsburgh, 23 U.S. at 133-135, 142.

189 The Plattsburgh, 23 U.S. 142-143. For news reports, see "Supreme Court," National Intelligencer, March 10, 1825; "Supreme Court," National Intelligencer, March 14, 1825; "Supreme Court," Aurora \& Franklin Gazette
} 
Moreover, that the alleged Spanish owner had kept on board the ship's prior owner and captain seemed to Story a strange and unwise business decision that only proved guilt. Their presence aboard was doubtfully uninvolved. Story asserted that any foreign merchant engaging in either a legitimate business or the slave trade would endeavor to do everything possible to avoid possible seizure by US vessels. "He cannot but know," Story reasoned, "that American cruisers are in search of those who violate our laws respecting this traffic; and he would deem it the highest imprudence to place his property in a situation in which it might justly be suspected of an admixture of American interests.” Pointing to the letters found aboard providing instructions to the Plattsburgh's supposedly former captain, Joseph Smith, as well as the testimony of Lieutenant Stringham, Story believed that it was obvious Smith was directing the ship's slaving voyage. The court concluded that the Plattsburgh's slaving mission had begun in Baltimore, within the jurisdiction of the United States. Rejecting Marino's assertions that the ship had been outfitted under his direction, Story held that the Plattsburgh had taken part in "a meditated infringement of the acts prohibiting the slave trade.” Future slaving voyages needed only to have begun their preparations in the United States to be in violation of US laws forbidding the slave trade to be subject to forfeiture. ${ }^{190}$

The Cyane's seizures marked the United States' first attempt to apply the laws enacted by Congress over the preceding decade. Although two of the criminal cases failed to result in convictions, Adolphe La Coste and Joseph F. Smith were convicted as slave traders in

(Philadelphia), March 22, 1825. For Story's earlier decision regarding the Jeune Eugénie, see United States v. The La Jeune Eugenie, 26 F. Cas. 832 (C.C.D.Mass. 1822).

${ }^{190}$ The Plattsburgh, 23 U.S. 140, 143-145. David Seaton depicted the Plattsburgh's voyage as the plan of Thomas Sheppard. Seaton, "Warts and All," 4-5. David Lynch interpreted Story's decision in Plattsburgh to declare that US courts had jurisdiction over cases involving slaving voyages commenced in the United States, regardless of whether the ship's owner was an American citizen. David Lynch, The Role of Circuit Courts in the Formation of United States Law in the Early Republic: Following Supreme Court Justices Washington, Livingston, Story, and Thompson (Portland, OR: Hart, 2018), 149. 
contravention of US law. Convicted before the 1820 Piracy Law took effect, their prison sentences, albeit brief, and fines, however small, fell within the ranges allowed by the Slave Trade Act of 1818. ${ }^{191}$ After the USS Alligator seized a handful of ships off the African coast in 1821, one of which set off the Jeune Eugénie affair with France, public perceptions of the slave trade's conduct shifted. Believing that the trade had been set on the course to extinction, it was believed, there would be no further need for Navy-led slave-trade suppression. The Navy's regular Africa patrols would be withdrawn, not to reappear for another twenty years. ${ }^{192}$

Reflecting on the cases, the National Gazette speculated on their impact. The initial arrival of the ships and their imprisoned crews had aroused public support of US slave-trade suppression, but whether that was to change the trade's conduct was unclear. The "salutary effect" of the ships' seizures and the testimony of Stringham and others that American sailors and vessels were engaging in the trade in great numbers had "produced a strong sensation in the public mind." This would, the Gazette predicted, spur public support for an expanded US Navy presence along the African coast to suppress the slave trade. "The success of the Cyane in so short a time," the newspaper explained, "shews what could be done with honest exertion and an adequate force. The United States may discharge their duty, without consenting to subject their shipping any where, in time of peace, to British search.” The Cyane's seizures showed that the

\footnotetext{
${ }^{191}$ An Act in Addition to "An Act to Prohibit the Introduction (Importation) of Slaves," §3-4, ch. 91, 3 Stat. 450, 451. Sections three and four of the act provided for fines between $\$ 1,000$ to $\$ 5,000$ and prison terms for between three to seven years. This applied to residents and citizens of the United States who prepared a ship to transport (section three) or transported (section four) a "negro, mulatto, person of colour" for the purpose of slavery.

${ }^{192}$ C. Herbert Gilliland, introduction to USS Constellation: On the Dismal Coast; Willie Leonard's Journal, 1859 1861, ed. C. Herbert Gilliland (Columbia: Univ. of South Carolina Press, 2013), 2; Oakes, Freedom National, 262; Canney, Africa Squadron, 11-12; Fehrenbacher, The Slaveholding Republic, 155-156. A good example of this perception among the American public is in a letter excerpt from Havana published in the New York Advocate in November 1820. "A schooner arrived at Matanzas after ten months voyage, with only twenty-five slaves." The Advocate added the following parenthetical: "A few more such voyages will render the presence of cruisers on the coast unnecessary." "Slave Trade on the Decline," New York Advocate, November 3, 1820. Fehrenbacher quoted a report of Matthew C. Perry from 1822, which seems to have ensured the patrols' termination. Fehrenbacher, The Slaveholding Republic, 155.
} 
United States could effectively contribute to the international slave trade's demise, an achievement not yet completed that demanded continued effort. ${ }^{193}$

But, even then, the existence of domestic slavery stood as a blatant cancer, undermining the nation's principles, according to the Gazette. The United States had to be "consistent" in its dealings with slavery. "To pass acts of death against the maritime slave trader," the Gazette declared, "and yet overlook the domestic negro driver, and preach in Congress that hereditary servitude is an institution expressly sanctioned by holy writ and natural law, and that it may be justified by convenience and profit; to admit with all honor and kindness into the Union, a community which persists in maintaining it upon those grounds, and without any colourable title of necessity, is to pursue a career of self-contradiction, destructive of the moral influence and good repute of our penal legislation." The newspaper argued that slavery's continued existence compromised the United States' ideals but that the Founders' vision for the United States bore a promise of freedom that had not yet been fulfilled. The 1808 Act Prohibiting the Importation of Slaves had been the prognosis that saw a path to the young nation's cure. It had set in motion the Founders' plan by which the scourge of slavery would be eradicated in the United States. In 1820, the Cyane administered the first dose of treatment, the beginning of American enforcement of the slave trade. Although the ship's seizures brought only two convictions of slave traders, their vessels, the vital means by which they conducted the trade, were forfeited, a tremendous financial loss. Through these cases, federal prosecutors learned the critical lesson that convicting individuals for slave trading would be harder than seizing their property. The cases that the

\footnotetext{
${ }^{193}$ National Gazette, “Slave Trade,” National Intelligencer, June 2, 1820.
} 
Cyane spawned would, therefore, serve as the basis for federal slave-trade suppression moving forward. ${ }^{194}$

\section{The Interim: Webster-Ashburton and the Amistad}

The years following the Cyane's successes saw the US Navy's temporary withdrawal from slave-trade suppression on the African coast. Although slave traders were taken to court for violations of the slave-trade laws, the Antelope decision and broader federal policy minimized the proactivity of enforcement. Many of the cases that arose relitigated the legitimacy of forfeitures and the distribution of prize money, as in the cases of the Josefa Segunda, which appeared and reappeared before the Supreme Court during the second half of the 1820s and throughout the 1830s. ${ }^{195}$ Coinciding with the antebellum period, these years would initially see subtle action taken against the slave trade. But naval enforcement, which had surfaced and submerged at the end of the early republic, would reemerge with renewed strength. With at least thirty-two court cases prosecuted during the period, ${ }^{196}$ steady progress would characterize the apparent lull during the period between the Antelope decision in 1825 and the Civil War, as the United States moved ever so slowly toward staunch slave-trade suppression.

Most significantly, larger, international forces ensured the United States' return to the coast of Africa. Although recent historians have framed it as a deliberate attempt to ensure

\footnotetext{
${ }^{194}$ National Gazette, "Slave Trade," National Intelligencer, June 2, 1820. An editorial from the same paper later that month offered a similar sentiment, referring to a Rhode Island newspaper's approval of the recent executions of pirates in Boston: "It is hoped and believed, that by the resolute execution of our wise laws, and the co-operation of other governments, the crimes of man-stealing and piracy will soon cease to exist. We led the way with the abolition of the slave trade. It will be equally to our honor, with the freest institutions in the world, that we have best succeeded in detecting, punishing, and preventing irregularities or outrages committed by our own citizens on the high seas, where, if any where, impunity might have been expected." "Remarking on the Late Executions for Piracy," National Intelligencer, June 22, 1820.

195 The Josefa Segunda, 23 U.S. 312 (1825); Governor of Georgia v. Madrazo, 26 U.S. 110 (1828); United States v. Preston, 28 U.S. 57 (1830); Emerson's Heirs v. Hall, 38 U.S. 409 (1839). The Josefa Segunda had been seized by a revenue inspector in April 1818 at La Balize, Louisiana.

${ }^{196}$ For full listing of slave-trade cases found in court reports between 1820 and 1865, see Appendix A.
} 
against British interference with domestic slavery, ${ }^{197}$ the Webster-Ashburton Treaty, signed in 1842, expressly provided for Anglo-American cooperation on the issue of slave-trade suppression. Agreeing to a "sufficient and adequate squadron ... in all not less than eighty guns," the United States and United Kingdom jointly swore to permanent patrols against the trade. ${ }^{198}$ The US Navy's Africa Squadron, created under the treaty's provisions, seized thirty-six ships in the following twenty years, with each taken to the United States and adjudicated under the slavetrade laws. ${ }^{199}$ But the sparse, infrequent seizures, coupled with the fluctuating size of the fleet, has led historians, such as Donald L. Canney, to deem the Africa Squadron unsuccessful, particularly when compared to the long-term success of the Royal Navy's anti-slave-trade patrols. ${ }^{200}$ Nevertheless, to dismiss the US Africa Squadron as a failure would be to ignore the realities of the antebellum US Navy. In the post-Webster-Ashburton period, except for one year, the US Navy consistently employed on average five ships - twelve percent of its entire fleet of thirty-three ships - to the slave trade's suppression. The Royal Navy, the largest navy in the world with 283 ships in active service which protected a worldwide empire, devoted thirteen percent of its entire fleet in 1837 - some eighteen ships — to the same task. For the US Navy to

\footnotetext{
197 George C. Herring, From Colony to Superpower: U.S. Foreign Relations since 1776 (New York: Oxford Univ. Press, 2008), 186-187; Matthew Karp, This Vast Southern Empire: Slaveholders at the Helm of American Foreign Policy (Cambridge, MA: Harvard Univ. Press, 2016), 52; Leonardo Marques, The United States and the Transatlantic Slave Trade to the Americas, 1776-1867 (New Haven, CT: Yale Univ. Press, 2016), 156-159. ${ }^{198}$ Webster-Ashburton Treaty, U.S.-U.K., August 9, 1842, 8 Stat. 572, 576 (1842). Interestingly, the ninth article acknowledged that the slave trade would continue so long as they could be sold in the Americas. "Notwithstanding all efforts which may be made on the coast of Africa for Suppressing the Slave Trade, the facilities for carrying on that traffic and avoiding the vigilance of cruisers by the fraudulent use of flags, and other means, are so great, and the temptations for pursuing it, while a market can be found for Slaves, so strong, as that the desired result may be long delayed, unless all markets be shut against the purchase of African negroes, the Parties to this Treaty agree that they will unite in all becoming representations and remonstrances, with any and all Powers within whose dominions such markets are allowed to exist; and that they will urge upon all such Powers the propriety and duty of closing such markets effectually at once and forever.” Webster-Ashburton Treaty, 8 Stat. at 576.

${ }^{199}$ For list of US Navy's Africa Squadron seizures, see Appendix B.

${ }^{200}$ Canney, Africa Squadron, xiii.
} 
commit a similar percentage to slave-trade suppression was, regardless of its ability to seize slavers, a far greater commitment. ${ }^{201}$

The slave-trade cases that arose during this period raised questions intertwined with the freedom principle. When a Jamaican-born slave, Curranee, who had immigrated to Georgia with his enslaver as a minor years earlier, learned of the United States' 1808 ban on the importation of slaves, he filed suit to recoup the amount that he had paid toward his freedom on the grounds that his servitude was nullified upon the age of twenty-one. The federal district court of Georgia agreed that he had been free since he entered the United States a decade prior. ${ }^{202}$ Contrarily, in a case where Louisiana-owned slaves had travelled abroad with their enslavers but returned unaccompanied, Chief Justice Roger B. Taney held that the slave-trade laws did not apply to temporary journeys outside the country, drawing a clear distinction between the property rights of domestic slavery and the importation of slaves. ${ }^{203}$ Even as judges limited the effects of the slave-trade laws, judicial precedent was slowly coming to affirm and reaffirm the United States' position against the slave trade.

In the antebellum period, the Amistad case has emerged as one of the most well-known cases involving the slave trade. Both rhetorically and practically, the Amistad's legal consequences were not insignificant. Admittedly, David Brion Davis and Howard Jones have suggested that the case's effects were more indirect, for the Amistad revealed the judicial system's antislavery potential. Forgoing these conclusions, Don E. Fehrenbacher, in his The Slaveholding Republic, insisted that its effects were limited to the rhetorical realm. Noting that it was a diplomatic "irritant" for the rest of the antebellum period, Fehrenbacher's Amistad was a

\footnotetext{
${ }^{201}$ For comparison of US and Royal Navy commitments to slave-trade suppression, see Appendixes C and D.

${ }^{202}$ Curranee v. McQueen, 6 F. Cas. 984, 984-985 (C.C.D.Ga. n.d.)

203 The Garonne, 36 U.S. 73, 73-79 (1837).
} 
hollow one. But his focus was purely on the Supreme Court's decision. From this, he concluded that "In spite of all the notoriety and emotionalism surrounding it ... It settled no major issue and contributed little to the development of American slave-trade law." ${ }^{204}$ But, as James Oakes has shown, John Quincy Adams' 1841 oral argument before the Supreme Court was a "précis of antislavery constitutionalism." In emancipating the slaves, the Supreme Court, he demonstrated, assented to Adams' argument. It accepted his contention that slavery was bound purely to the jurisdictions that provided for it with legislation. ${ }^{205}$ The Amistad case, therefore, was a critical step toward the expansion of the freedom principle beyond the United States' borders.

The Amistad case was as much the victory of legal antislavery as it was of the new forms of immediatist abolitionism. Radical abolitionists at the time saw the Supreme Court's verdict as a measurable success through which their broader efforts could be justified. Their force was certainly essential in mobilizing public opinion in the Africans' favor and spurred the essential donations that allowed their litigation to succeed. ${ }^{206}$ However, their conception of where the case

\footnotetext{
${ }^{204}$ Fehrenbacher, The Slaveholding Republic, 195.

${ }^{205}$ Oakes, Freedom National, 35.

${ }^{206}$ Rediker, The Amistad Rebellion, 231. For example, see "Moneys Received for African Prisoners," Emancipator, September 26, 1839. By September 24, 1839, the Amistad Committee had raised \$861.75. A concern for how the abolitionist movement was being characterized in court as well as in newspapers across the country undeniably underlays the early correspondence between abolitionists dealing with the Amistad case. A. F. Williams, appointed by the committee to travel with a party of investigators, including the Connecticut US attorney, to the location of the Amistad's seizure, exemplified this in his report following the journey. The report reads as reconnaissance. Williams was more interested in the conversations between US officials, particularly Lieutenant Meade, and Ruiz and Montez than the landscape of Montauk. "Among the wonderful statements of Lt. Mead," he wrote, "was that L. Tappan was a very bad man \& had no character in N. York \& that Montez was a fine old Gentleman \& was not capable doing a mean thing." "A. F. Williams Report on the Visit to Culloden Point, Long Island," 23 October 1839, Doc. No. F14711, American Missionary Association Archives, Amistad Research Center, New Orleans. An anonymous abolitionist who witnessed the initial hearing at the City Hall in New London noted in a letter to the editor of the Emancipator that the attorney for Ruiz and Montez had called the Africans' advocate an "arch fiend" and "expressed a wonder that he, the "bosom friend of Jinqua [Cinque],' should 'dare to come into an American court, \& show his face among white men,' etc. etc." The witness was shocked at the accusation. "That a foreigner," he wrote, "the counsel of foreign slave-traders - should be permitted, before an American judge, to utter such language respecting an American citizen - one who had been laboring - in defence of abused men from a far distant land, and little children torn from their parents and reduced to slavery - is marvellous." Concluding, the abolitionist returned to the letter's intended purpose, writing, "While attending on these proceeding's I blushed for my country to hear lawyers, in this professedly free country, and in this free ... State, talk of the Spaniards having 'bought' \& 'owned' these helpless victims of their lust, cupidity \& tyranny; and vindicating the claim of their clients to these Africans as
} 
fit into the effort for nationwide emancipation importantly recalls the strategy of antislavery lawyers during the period. The abolitionist Lydia Marie Child, for example, clearly rationalized the Amistad case as part of a long-term legal strategy of immediatism in an editorial for her AntiSlavery Standard in the summer 1841. The Emancipator endorsed her view, publishing the essay in its July 22, 1841, issue. In it, Child explored the answer to the question "What have you done?" referring to the "occasional despondency" felt among abolitionists when their copious efforts failed to bring about marked results. "Let those who ask what we have done," she wrote, "look at the generous excitement, the universal public sentiment, excited in behalf of the Amistad captives." 207

The Amistad was part of a larger strategy, Child stressed. She described one instance in which a Philadelphia abolitionist was questioned on the success of his work. "What have you abolitionists done? The colonizationists have done something; they have at least transported a few thousand negroes to Africa; but what have you done, except excite an uproar?,"' he was asked. "The man responded, 'Some men might choose to supply Philadelphia with water, by carrying it down to Fairmount in a gill cup; and if they worked with diligence, and had plenty of money to hire carriers, they might soon point to a barrel full, as the result of their labors. This the colonizationists are doing. Meanwhile, we abolitionists are laying the pipes, which shall conduct the water all over the city, and give every man the benefit of the whole reservoir." Child saw abolitionism's efforts, no matter how small, as victories for the enslaved. "Not in vain have we worked with diligence and zeal, at laying the pipes," she asserted. "All over the land are proofs that the water has been conveyed. No where $[s i c]$ in the free States can slaves be hurried off into

their property ... Why is there so little sympathy for oppressed humanity?" "Article, the Spaniards—Ruiz and Montes," October 1839, Doc. No. F1-4715, American Missionary Association Archives, Amistad Research Center, New Orleans.

${ }^{207}$ Lydia Marie Child, “What Have You Done?” Emancipator (New York), July 22, 1841. 
the power of infuriated masters, without judge or jury. One after another, the State Legislatures have granted such unfortunate individuals a fair trial, while people grant them abundant sympathy." She concluded, "There is no need to inform the South, at least, that it is now much more difficult than of old to secure a runaway slave." ${ }^{208}$ To Child, the abolitionist fight would crescendo in emancipation. That emancipation would, however, result from the careful construction of a legal framework by which every enslaved person would be removed from bondage. The Amistad was simply a step toward a future time in which freedom reigned across the entire globe.

\section{"It Is Truly Dignified and Just, Right and Salutary"}

Forty years of legal groundwork would be vindicated following the inauguration of a Republican administration in 1861. At noon on February 21, 1862, Nathaniel Gordon was informed that his execution would be carried out before the hour's end. In his cell at New York City's Halls of Justice, known as the "Tombs," a deputy US Marshal helped him get dressed, administered a tall glass of whisky, and tied his arms to lead him to the gallows. Gordon desperately hoped that President Lincoln would save him from his fate. His sentence had, after all, been postponed before. Nearly three weeks prior, Lincoln had ordered his execution be delayed from its original date, February 7. He, along with countless friends and family, had sent petitions to both judicial and executive branches, pleading for his sentence to be reduced. His attorney had met with President Lincoln and had petitioned the Supreme Court for a writ a certiorari, both to no avail; and his wife had met with Mary Todd Lincoln while her son Willie lay ill on his deathbed. The President, however, remained adamant that Gordon's sentence be carried out. The law was clear. Seeing it as his duty not to offer even a commutation, Lincoln

\footnotetext{
${ }^{208}$ Lydia Marie Child, “What Have You Done?” Emancipator (New York), July 22, 1841.
} 
noted in his stay-of-execution order on February 4 that the only reason for the postponement was that, in all the time Gordon had spent soliciting a change in his sentence, the prisoner had not taken the time to reconcile himself with God. "In granting his respite," Lincoln wrote, "it becomes my painful duty to admonish the prisoner that, relinquishing all expectation of pardon by Human Authority, he refer himself alone to the mercy of the Common God and Father of all men." Nathaniel Gordon became the first and only person that the United States ever executed for slave trading. ${ }^{209}$

Gordon's story began four decades earlier when he was born in Portland, Maine, in 1826. All Gordon's life, US law maintained that slave trading was piracy, but no administration during his nearly forty years had followed through with the statutorily defined punishment as Lincoln would. It is likely that he had long been involved in the slave trade and that his father, also called Nathaniel, was, too, a slave trader. As James A. Rawley pointed out, a Nathaniel Gordon of Portland, Maine, was charged in the Southern District of New York for importing a slave from

209 “The Execution of Gordon, the Slave-Trader," Harper's Weekly, March 8, 1861, 150; Ron Soodalter, Hanging Captain Gordon: The Life and Trial of an American Slave Trader (New York: Atria Books, 2006), 197-200; Abraham Lincoln, "Respite of Execution for Nathaniel Gordon," February 4, 1862, GLC00182, Gilder Lehrman Collection, Gilder Lehrman Institute of American History, New York. Ron Soodalter's Hanging Captain Gordon is the most recent book-length work on the Gordon case. Research for this thesis's section on the case began by using that study, suggesting a narrative framework and source base from which to draw. While Hanging Captain Gordon bears a clear, well-written narrative, the documentary foundation is, at times, undependable. Soodalter rooted his narrative in the professional histories of James Rawley, The Transatlantic Slave Trade (New York: W. W. Norton, 1981), Warren S. Howard, American Slavers and the Federal Law: 1837-1862 (Berkeley: Univ. of California Press, 1962), and Don E. Fehrenbacher, The Slaveholding Republic: An Account of the United States Government's Relations to Slavery, ed. Ward McAfee (New York: Oxford Univ. Press, 2001). But Soodalter often took these works at face value, providing little sense of a historiographical debate. Source notation is occasionally hard to follow or inaccurate and almost always sparse. Nevertheless, as a trade publication, the book well fulfills its purpose, and these criticisms should not diminish the entire work. Rather, the author of the present study encourages researchers interested in the Gordon case to begin with Soodalter but stresses the need for readers to be attentive as to source base. Whenever possible, this chapter confirms details from Gordon's life and trial with the reports of the New York Times and New York Herald. William Lee Miller, “'I Felt It to Be My Duty to Refuse': The President and the Slave Trader," in Lincoln Revisited: New Insights from the Lincoln Forum, ed. John Y. Simon, Harold Holzer, and Dawn Vogel (New York: Fordham Univ. Press, 2007), 147-168. Miller stressed the moral imperative that seems to drive Lincoln's "respite" order. It was the slave trade that Lincoln had long considered to be a true evil in the world, and Gordon's case was hardly the time to show mercy, especially when compared to the significant number of persons he had placed in bondage. 
Guadeloupe in 1838. By 1848, a man of the same name, captaining the ship Juliet, was pursued and boarded off the coast of Rio de Janeiro by the USS Allegheny. An eleven-hour search yielded no damning evidence of the ship's slaving character, and the Juliet was allowed to go on its way. It was rumored that, only a few weeks later, the Juliet returned to Brazil with an enslaved African cargo. ${ }^{210}$ Although it is uncertain whether this was Gordon, his father, or another man going by the same name, Ron Soodalter identified this 1848 journey as Gordon's first slaving voyage. ${ }^{211}$ Three years after the Juliet's voyage, a Nathaniel Gordon returned to Brazil with the Camargo, bringing 500 enslaved Africans. Soon after, the ship was detained, and its crew was charged for slave trading. But Gordon was nowhere to be found. Not insignificantly, the US consul— the embodiment of the federal government abroad—encouraged Brazilian authorities to prosecute the crew. He believed, however, that Gordon had snuck back to the United States with impunity. ${ }^{212}$

\footnotetext{
${ }^{210}$ James A. Rawley, "Nathaniel Gordon, the Only American Executed for Violating the Slave Trade Laws," Civil War History 39, no. 3 (September 1993): 219-220; Soodalter, Hanging Captain Gordon, 15-17. Rawley identified the 1838 indictment of a Nathaniel Gordon, who was the master of the Dunlap, a brig from Portland, Maine, in the Circuit Court for the Southern District of New York. However, he provides no further information as to the case's outcome. "The criminal case filed in the National Archives does not disclose the outcome of the jury trial," he explains. A brief search through newspaper databases available from Milner Library yields a handful of results related to what is, presumably, the same case. That Nathaniel Gordon is reported in the New York Herald on July 31, 1838 , to have been charged for "importing a negro boy from a foreign country to be held as a slave in the United States." The Emancipator, quoting from the reporting of New York Sun, contains the following passage from July 12, 1838: "On Saturday, a Mr. Lambert Bersin, of Point Petre, Guadaloupe [sic], was brought up for examination before Justice Lownds, in the U.S. Court, in the absence of Judge Betts, on the charge of having brought with him, from the above place, to the United States, a slave named George Washington, with intent to hold him to labor here, contrary to the laws of the U.S. The case coming to the knowledge of a colored citizen, Mr. Ruggles, who takes an active interest in such matters he laid the case before the District Attorney, Mr. Price, who caused Mr. Bersin, the claimant of the slave, and Nathaniel Gordon, Captain of the brig Dunlap, of Portland, Maine, who it is said, permitted the slave to be secretly conveyed on board his vessel at Point Petre, and smuggled into the United States, to be arrested forthwith. Judge Lownds, after a hearing of the testimony in the case, ordered Mr. Bersin to find bail in $\$ 10,000$ for his appearance to answer the charge at the next term of the court, and for the same purpose, Capt. Gordon was held to bail in $\$ 5000$." The New York Spectator reported on August 2, 1838, that a grand jury dismissed the charge the day prior. "United States Circuit Court," New York Herald, July 31, 1838; New York Sun, "Bringing Slaves to the United States," Emancipator (New York), July 12, 1838. "U.S. Circuit Courts," New York Spectator, August 2, 1838.

${ }^{211}$ Soodalter, Hanging Captain Gordon, 17.

${ }^{212}$ Soodalter, Hanging Captain Gordon, 14-15; Rawley, "Nathaniel Gordon," 219-220. It is noteworthy that, according to Soodalter, the Camargo's 1851 voyage was the last cargo of Africans known to have been delivered to Brazil. Soodalter, Hanging Captain Gordon, 17. Soodalter quoted heavily from the New York Times' tale of
} 
The consul's assumption proved correct. For it was not until 1861 that Gordon would face the long-deserved consequences for his slave trading. Gordon had departed New York on his ship, the Erie, in the spring 1860, destined for Havana. There, the port authorities and the US consul approved the ship for travel, and Gordon and the Erie cleared for the Congo River on April 9. ${ }^{213}$ As the Erie left the port of Havana, the US consul contacted the US Navy and State Departments to alert them of the ship's impending presence on the African coast. ${ }^{214}$

By August 7, the Erie laid anchor at Sharks Point, inside the mouth of the Congo. Over the preceding few weeks, Gordon had negotiated with local traders to acquire an enslaved cargo. In exchange for 150 hogsheads of whisky, Gordon received 897 Africans. Half adults and half children, the youngest was only six, the oldest just forty. Gordon jammed them together in the ship's small hold. The fit was revoltingly tight. As Soodalter illustrated, the Nightingale, a slaver intercepted by the US Navy around the same time as the Erie, held 961 wedged-together slaves at the time of its capture, but it was twice the size of the Erie. Gordon was swift. Without making extensive considerations as to their food and water, he had stowed away the Africans and made sail within only forty-five minutes. ${ }^{215}$

As dawn turned to daylight the next day, the Erie was fifty miles away from the Congo's mouth destined for Havana. Spotting the Erie sailing northward, the USS Mohican, a ship of the Africa Squadron, began pursuit. Gordon noted his pursuer and, incorrectly thinking the Mohican

Gordon's life published the day after his execution. He generally accepted the Times' treatment, merely responding to its "Dickensian" tale of Gordon's turn from respectability to evil. Soodalter emphasized that, rather than degenerating into criminality, Gordon was "taking over the family business," pointing to his father's 1838 indictment in New York. It is important to note, however, that, while it is certainly likely, it is not definitely known that this was Gordon's father. For that Times article, see "The Execution of Gordon: Scenes Incident to His Last Moments," New York Times, February 22, 1862.

213 "The Case of Gordon: The Facts - the Testimony_Exertions of the District-Attorneys, Past and Present," New York Times, February 21, 1862.

${ }^{214}$ Soodalter, Hanging Captain Gordon, 30-34.

215 "The Case of Gordon," New York Times, February 21, 1862; Soodalter, Hanging Captain Gordon, 53, 56-57. The Nightingale displaced 1,066 tons, while the Erie was around 500 tons. Soodalter, Hanging Captain Gordon, 56. 
was a British warship, ordered the Erie to hoist an American flag to deter against boarding.

However, the Mohican was an American vessel. It was charged with suppressing the slave trade and, in turn, enforcing US law. By eight o'clock on the morning of August 8, the Mohican, having put a shot across the Erie's bow, sent a boat to inspect the ship. ${ }^{216}$ Lieutenant John W. Dunnington, a Southerner, led the boarding party. ${ }^{217}$ When he arrived, the crew put up little resistance, acquiescing to his orders. He later testified that "when I got on board I met a man on the gangway; as I went over I spoke to him, and asked him if he was captain of the ship; he did not answer me; made a motion, pointed towards Mr. Nathaniel Gordon; I advanced towards Mr. Gordon, who offered me his hand, and asked me to walk down in the cabin." But Gordon offered little more help. Dunnington recalled, "I asked him (Gordon) for the ship's papers; he replied she had none; made no other answer; I asked him if he was captain; he answered, 'No."' When Dunnington enquired as to the captain's identity, Gordon conveniently claimed that "the captain died in the Congo" and that he did not know who was now in command of the ship. Dunnington ordered Gordon to lower the Erie's colors and informed him that, although he had not seen any slaves aboard, the Mohican was seizing the ship as its prize. ${ }^{218}$

While Gordon and the Erie's crew complied with Dunnington's order, Dunnington heard voices from belowdecks. “The negroes were shouting, yelling, crying, etc.," Dunnington remembered. "I looked down to see how thick they were; I saw a cargo of naked negroes, negresses and children, all stark naked except some few of them; they were all closely stowed,

\footnotetext{
216 "The Slave Trade: The Case of the Erie-Nearly Nine Hundred Slaves on Board," New York Herald, October 9, 1860.

217 "The Case of Gordon," New York Times, February 21, 1862; Soodalter, Hanging Captain Gordon, 109. According to Soodalter, Dunnington was from Kentucky. The article of the New York Times notes that, by the time of Gordon's trial because he had resigned his commission and joined the Confederate Navy.

218 "The Slave Trade: The Case of the Erie - Nearly Nine Hundred Slaves on Board," New York Herald, October 9, 1860. This article reports in full the testimony of Lieutenant Dunnington from the day prior (October 8) before the US Commissioner's Court.
} 
spoon fashion; the stench that came up was very bad; there were none dead or appearing to be dying." ${ }^{219}$ Lieutenant Henry D. Todd, who boarded the Erie after Dunnington's initial inspection, later testified that "it was impossible to put a foot down on the deck without treading on a nigger." The stench of death and human waste was putrid. "Some of the negroes," Todd recalled, "had corn cobs and cotton in their nose to keep the stench away; some of them were covered with running sores, some of them fell sick and died very rapidly." ${ }^{220}$ Concerned about the condition of crushed captives below, Dunnington questioned Gordon about the extent of the Erie's provisions. Gordon, careful not to offer too much information, only stated that he did not know whether the ship had enough food and water to make it the 1,500 miles to Monrovia. When the Erie reached the Liberian capital fifteen days later, just 867 Africans disembarked; thirty had died along the way. ${ }^{221}$

A grand jury was empaneled shortly after the Erie's return to New York on October 3, $1860 .{ }^{222}$ It indicted Gordon on five counts under the fourth and fifth sections of the 1820 Piracy Act. ${ }^{223}$ While this statute provided for capital punishment against those who engaged in the slave

219 “The Slave Trade: The Case of the Erie," New York Herald, October 9, 1860.

220 "The Slave Trade," New York Herald, June 19, 1861.

221 "The Slave Trade: The Case of the Erie," New York Herald, October 9, 1860; "Law Reports: Slave-Trade," New York Times, June 19, 1861. Although not explicitly stated, Soodalter implied that these formerly enslaved Africans were immigrated to Liberia as paid laborers. Soodalter, Hanging Captain Gordon, 62, 64-65.

222 "The Slave Trade: The Capture of the Slaver Erie," New York Herald, October 4, 1860; "News of the Day," New York Times, October 4, 1860; "The Slave Trade: United States Circuit Court; Before Hon. Judge Nelson," New York Herald, October 26, 1860. The grand jury was empaneled on October 25, 1860.

223 "The News," New York Herald, November 3, 1860. All five counts were alleged as violations to the 1820 act. "The Slave Trade: United States Circuit Court; Before Hon. Judge Nelson," New York Herald, October 26, 1860. Judge William D. Shipman elucidated the charges on which Gordon was indicted in his charge to the jury in Gordon's first trial, on June 19, 1861. The first count of the indictment alleged the Erie was owned by a US citizen (Gordon) and that, onboard, US citizens forcibly detained Africans for the purpose of making them slaves; the second charged that the Erie was navigated by a citizen of the United States, requiring proof that Gordon was the voyage's architect; the third, to cover the prosecution's bases, charged that the Erie was a foreign vessel engaged in the slave trade; Shipman did not provide instructions on the fourth and fifth counts in his charge. "The Slave Trade: The Slaver Erie- Charge of the Judge," New York Herald, June 20, 1861. Gordon was indicted with two others, William Warren and Daniel Hall, on November 2, 1860. Because Hall did not have the means to pay the requisite fine, Shipman sentenced him to nine months' imprisonment and a \$1 fine. Shipman stressed how lucky he was: "As the District-Attorney is satisfied that the man has no means to pay a fine, I don't feel inclined to put one upon him, as it would only prolong his imprisonment without any likelihood of its being collected ... you may congratulate 
trade, it had only been successfully used once before, five years earlier, in United States v. Smith.

But President Buchanan had been quick to pardon the alleged slave trader, the German-born Smith. ${ }^{224}$ In 1860, Buchanan's appointee as US Attorney for the Southern District of New York, James I. Roosevelt, appeared reluctant to proceed with Gordon's prosecution. He thus proposed a plea bargain. In exchange for the names of Gordon's financial backers, the slave trader could escape with a short prison sentence and a $\$ 2,000$ fine. ${ }^{225}$

When news broke of the offer, the Republican press lambasted Roosevelt's feeble attempt to root out the network of slavers based in New York City. "In the view expressed by Judge Roosevelt, that public opinion, both at the North and South, has ceased to regard this crime as deserving a pirate's doom — and in his further statement that, even in case of conviction of the full offence, the President [Buchanan] would 'probably pardon' the guilty man or men," Henry J. Raymond, editor of the New York Times, wrote, "we confess to a shock of not pleasant surprise, a stunning of all the moral senses, and a confusion of ideas, such as must result whenever a deeply-rooted and long-venerated belief is swept suddenly away from before us." The precedent of presidential pardons could not hold. The slave trade had to be stamped out then and forever. "The Slave-trade is not, unhappily, a plant of such weak growth in our midst that it requires to be watered in advance with these tear-drops of Executive clemency. Rather is it [sic] a spreading and poisonous weed, requiring vigorous arms, unflinching industry and the most unyielding discharge of every duty on the part of our law officers charged with its repression."

\footnotetext{
yourself upon getting off so easily. The crime you were engaged in was a very heinous one, and, if caught engaged in it again, the punishment would be severe." "The Slave-trade: United States Circuit Court," New York Times, February 27,1862 . Warren, similarly situated financially, was sentenced to eight months' imprisonment and a $\$ 1$ fine. "United States Circuit Court," New York Times, February 28, 1862. Soodalter incorrectly cited these two separate articles collectively as having been published on February 26, 1862. Soodalter, Hanging Captain Gordon, $287 \mathrm{n} 13$.

${ }^{224}$ Howard, American Slavers and the Federal Law, 195; "The Execution of Nathaniel Gordon," New York Times, February 22, 1862.

${ }^{225}$ Soodalter, Hanging Captain Gordon, 75.
} 
Raymond concluded, "If Mr. Buchanan desired to signalize the last days of his unhappy term by

giving assurance of impunity to this crime, he could not have chosen a better means than the

declarations made by Judge Roosevelt." ${ }^{, 26}$ Although there was public sentiment advocating

against Gordon's punishment, a slave trader could no longer get off scot-free by $1860 .{ }^{227}$

226 "Punishment of the Slave-trade to Be Abolished," New York Times, November 1, 1860. This editorial was reprinted in the Times' summarizing retrospect the day after Gordon's hanging on February 21, 1862. Soodalter cited this reprinting instead of the original. Soodalter, Hanging Captain Gordon, 275n21. Roosevelt was an appointee of President Buchanan. Upon Lincoln's ascension to the presidency, the New York Times urged the Democrat's immediate dismissal, along with that of the incumbent US marshal, primarily for their incompetence in handling slave trade cases. "While the President has an undoubted right to weigh carefully the claims of all candidates for Federal employment, there are two of Mr. Buchanan's appointees in this City whose instant removal is demanded alike by humanity and justice. We refer to Marshal Isaiah Rynders and District-Attorney Roosevelt, two officials under whose benignant and fostering protection the Slave-trade has established itself amongst us as a secure and influential business-interest." "Rynders and Roosevelt," New York Times, March 18, 1861. Regarding the substantial volume of slavers outfitted for the trade in New York City, James A. Rawley refers to the estimates of the British consul in New York, which suggested that seventy-four of 170 slave trading voyages between 1859 and 1862 had originated from the port of New York. Rawley, "Captain Nathaniel Gordon," 221. This editorial came after building frustration among New Yorkers that slave traders were escaping punishment. Raymond wrote in the New York Times, on October 25, 1860, that "It is notorious that a slave-trader tried in New-York is almost certain to escape punishment, though proof of his guilt be demonstrated beyond a peradventure." "The Slave-Trade in NewYork," New York Times, October 25, 1860. George Templeton Strong shared a similar negative opinion of Roosevelt in his diary on November 2, 1860 - the day Gordon was indicted - tying Gordon's punishment to the brewing sectional crisis: "Think I shall vote a Repubn. Ticket next Tuesday. One vote is insignificant, but I want to remember that I voted right at this grave crisis. The North must assert its rights, now, \& take the consequences." In his next paragraph, he gave an example of such a right: "Think of Jas. I. Roosevelt, U.S. Dis: Atty, bringing up certain persons under indictment for piracy as slavetraders, to be arraigned, the other day, \& talking to the Court about the plea the defendts should put to, \& saying that 'there had been a great change in public sentiment about the Slave trade'--\& that 'of course the Presdt. would pardon the defendts, if they were capitally convicted'!!! Is Judge Roosevelt more deficient in common sense or in moral sense? If we accede to Southern exactions, we must re-open the Slave trade with all its horrors - establish a 'Slave Code' in the territories, \& acquiesce in a decision of the U.S. Supreme Court in the Lemmon case that will entitle every Southerner to bring his slaves into N.Y. \& Massachusetts $\&$ keep them there. We must confess that our Federal government exists chiefly for the sake of nigger-owners. I can't do that. Rather let South Carolina \& Georgia secede. We will coerce \& punish the traitorous seceders if we can; but if we can't, we are well rid of them." George Templeton Strong, November 2, 1860, George Templeton Strong Diary, vol. 3, 1854-1862, p. 353, George Templeton Strong Diary, 1835-1875, New York Historical Society Museum \& Library, New York, https://digitalcollections.nyhistory.org/islandora/object/nyhs\%3Astrong.

${ }^{227}$ The New York Times published an editorial on February 22, 1862, that noted the ultimate petition presented to Lincoln bore the names of 25,000 citizens. It follows with a commendation of Lincoln's restraint; he was "a man to whom the voice of duty is all-powerful." But it emphasized that the statutorily mandated punishment was long overdue to be carried out. "Thus the majesty of the law has been vindicated, and the stamp of the gallows has been set upon the crime of slave-trading in so forcible a way that it will not soon be forgotten. And it was time. That crime has been far too lightly thought of among us of late. That it has been so, Gordon himself was a living proof ... why should he four times have gone into a traffic to which the law had affixed the penalty of death? Because our commercial communities had become demoralized upon the question. The 'cursed greed of grain' had caused them to shut their eyes, had deadened their consciences when the Slave-trade was in question." "The Execution of Nathaniel Gordon," New York Times, February 22, 1862. 
With the entry of the Lincoln administration in March 1861, Republican Edward Delafield Smith replaced Roosevelt as US Attorney. While his attempts to avoid a trial in the Gordon case had seemed to foreshadow an abandonment of the slave trader's charges, Roosevelt had failed to act on the case until the end of his tenure. Gordon meanwhile sat in prison; as weeks turned into months, he still waited for word of his almost-certain release. ${ }^{228}$ But Smith's arrival brought sudden changes. Within three months of his appointment, Smith constructed the government's case against Gordon. And, on Tuesday, June 18, 1861, the trial began with the new US attorney personally conducting the prosecution. ${ }^{229}$

Smith opened his case by grounding his argument in the freedom principle upon which antislavery advocates and the fledgling Republican Party had steadily built over the preceding decades. He referred to Gordon's attorney, Philip J. Joachimsen, who as part of the jury selection process had asked a prospective juror about his opinions on slavery. US attorney Smith recalled, "The question put to the juror was-as to what ought to be done or could be done with the slaves which inhabit that section of the country?" But the Gordon case was, Smith emphasized, not a matter of slavery "policy" within the United States; rather, the case dealt with a "cruel and nefarious" trade occurring on the high seas. "Here a crime is charged against a person-a crime, though arising from the slave traffic, has no connection whatever with slavery as it at present exists in the Southern states. ${ }^{230}$ His emphasis drew a line between the foreign slave trade and domestic slavery. And that line meant the critical difference between an institution within the federal government's purview to suppress and one considered untouchable, only subject to municipal law.

\footnotetext{
${ }^{228}$ Soodalter, Hanging Captain Gordon, 88.

229 "The Slave Trade," New York Herald, June 19, 1861.

230 "The Slave Trade," New York Herald, June 19, 1861.
} 
In the Gordon case, jurors were not simply asked to convict a man accused of slave trading, Smith argued. Of course, whether Gordon was convicted would determine whether the United States would allow the trade to continue. But Smith suggested that the case, too, bore the potential to protect the delicate balance between free and slave states. To suppress the slave trade - one of the few ways that the federal government could intervene in the slavery question during the antebellum period - was a means by which slavery could be restricted from spreading further into the territories. As the New York Herald explained, "whether thus being permitted to proceed, it shall be further permitted in its effects and results to crowd the virgin soil of the nation of the Territories of the country, indirectly through Cuba, with negroes to the exclusion of the white man." ${ }^{231}$ The continued influx of slaves from abroad would expand the enslaved population of the South to levels that would undoubtedly menace, or even level entirely, the cordon of freedom. While the prosecution of a slave trader did not directly deal with domestic slavery, the federal government's failure to prosecute would therefore undergird the strength of the Slave Power.

Most importantly, however, Gordon's prosecution harked back to the nation's revolutionary founding. To Smith, the 1820 Piracy Law under which Gordon had been brought to trial was a clear legacy of the Founders' vision for slavery's existence within the federal system. "The statute under which the indictment is founded," he highlighted, "is a statute passed by Congress, by that Congress who has bequeathed to us the form of constitution under which we live." It was an act that both Northerners and Southerners had passed because of its importance to the founding generation. "A statute," Smith continued, "the propriety of which and the necessity for which, was universally admitted, and all the patriots of the land, represented in

\footnotetext{
231 “The Slave Trade,” New York Herald, June 19, 1861.
} 
Congress by statesmen of character from every State, voted with alacrity and earnestness." 232 To neglect the laws against the slave trade was, as Smith argued, to forgo the Founders' vision for a nation unshackled from the international slave trade.

Over the course of that Tuesday and into Wednesday, Smith and the prosecution presented their case. Smith established, through witnesses, that Gordon and his parents had lived in Maine since at least two years of age, making it unlikely — albeit not impossible — that he was not an American citizen. ${ }^{233}$ To testify on the Erie's seizure, the prosecution had been unable to get Lieutenant Dunnington, the first of the Mohican's officers to inspect Gordon's Erie, because, as a native of Tennessee, he had resigned from the US Navy just a few months earlier and joined the Confederate Navy. ${ }^{234}$ Smith nevertheless received reliable and detailed testimony from Lieutenant Todd, who attested to Gordon's knowledge of the slaves' condition and how to care for them. He noted that the defendant had referred to Portland, Maine, as "home" and that he consistently conducted himself as though he were "responsible for the ship." Within a day and a half, Smith had presented his case. ${ }^{235}$

Gordon's attorney, Philip Joachimsen, had successfully prosecuted the slaver James Smith half a decade earlier. For Gordon's defense, Joachimsen wielded a three-part strategy, which addressed several contingencies. Through his initial argument, he hoped to show that Gordon was merely a passenger aboard the Erie, who had been traveling in the interior of Africa. Because slave ships were some of the only vessels able "to get away from there," Gordon had just happened to seek passage by way of a slaver. Even if Gordon had been involved in the

\footnotetext{
232 “The Slave Trade," New York Herald, June 19, 1861. (Emphasis added.)

233 “Law Reports: United States Circuit Court, Before Judge Shipman: Slave-Trade,” New York Times, June 19, 1861.

234 “Law Reports: United States Circuit Court_June 19; Before Judge Shipman,” New York Times, June 20, 1861; "The Case of Gordon," New York Times, February 21, 1862.

235 “The Slave Trade," New York Herald, June 19, 1861.
} 
slaving enterprise, Joachimsen maintained that the United States did not have jurisdiction in the case because the Atlantic did not flow into the Congo. As the Atlantic's tide "did not ebb and flow," the river was bound within the jurisdictions of Portugal all the way to its mouth. Even had Gordon been the ship's captain, Joachimsen argued, a Spanish captain, officers, and crew replaced the Erie's original contingent before the Africans were brought aboard two days before the Mohican intercepted it. But, regardless of these points, Joachimsen maintained that Gordon was not an American citizen to begin with, thereby immune to prosecution under the Piracy Law. To support these assertions, Joachimsen called Gordon's mate, William Warren, whose testimony conveniently left little room for Gordon to have been the mastermind of the Erie's journey. Warren, also under indictment for the same charge, claimed that "he joined the Erie in England, went from thence to Havana and thence to the Congo." Warren claimed that "After the negroes were shipped, the vessel went to sea under the direction of the Spanish captain and that he did not see Capt. Gordon do anything after the negroes were taken on board." ${ }^{236}$ Filled with inconsistencies and alternative explanations, Gordon's falsehood-based defense almost seemed to underscore his guilt. But it was with this story that Joachimsen rested his case within less than a day.

The next morning, June 20, 1861, Judge William D. Shipman offered a charge to the jury. Laying out the statutory requirements for conviction, he made little effort to veil his own opinions. When considering Warren's testimony, he urged they use caution: "The defence has offered the evidence of a person who is indicted as an accomplice in this same offence as to this transaction in the Congo River, and there is no other evidence to show that the national character of this vessel was changed but his statement of what took place there." He stressed that "The

236 “Law Reports,” New York Times, June 20, 1861. 
testimony of accomplices is to be scrutinized in the light of the circumstances." And, as to Gordon's claims of not being an American citizen, Shipman noted that "It is fair for you from the fact that no evidence is given on the part of the defendant to show anything to the contrary that he has no such evidence." After the jury deliberated that evening, they returned the following morning in disagreement. Although the press speculated on the jury's balance, Shipman nevertheless declared a mistrial. ${ }^{237}$ Whether Gordon was even to be convicted seemed uncertain. Smith quickly moved for a new trial, but it would not be until the fall that it would recommence. Judge Shipman had ordered that jurors be brought in from outside the city and slated the trial to begin at the beginning of July. ${ }^{238}$ But, by July 15 , the case was indefinitely postponed because of the availability of witnesses. ${ }^{239}$ When the parties returned to court on November 6, 1861, Smith and Joachimsen reenacted their previous presentations, calling most of the same witnesses and relying on the same arguments for the next three days. After the presiding judge, Supreme Court Justice Samuel Nelson, issued his charge to the jury, the jurors returned with their verdict within twenty minutes. Like the first trial, it had lasted two days. Gordon's defense had presented a weak and nearly self-defeating argument. But, this time, Gordon had been found guilty. ${ }^{240}$

On November 30, 1861, Judge Shipman sentenced Gordon. His remarks condemned both the slave trade and the particular cruelties of Gordon's case. "The evidence of your guilt was so

\footnotetext{
237 "United States Circuit Court," New York Times, June 22, 1861; "United States Circuit Court: Before Hon. Judge Shipman," New York Herald, June 22, 1861. According to the Times, the split was seven jurors for conviction to five against, whereas the Herald claimed it was ten for and two against.

238 "United States Circuit Court-June 22: Before Judges Shipman and Betts; Jury from the Country," New York Times, June 22, 1861; "The Slave Trade-The Erie: United States Circuit Court; Before Hon. Judge Shipman," New York Herald, July 3, 1861.

239 "United States Circuit Court: Before Hon. Judge Shipman," New York Herald, July 17, 1861.

240 "The Slaver Erie: United States Circuit Court; Before Judges Nelson and Shipman," New York Times, November 8, 1861; "United States Circuit Court: Trial and Conviction of Captain Gordon, of the Slaver Erie," New York Herald, 9, 1861; "Law Reports: The Slaver Erie; Verdict of Guilty Against Gordon," New York Times, November 9, 1861.
} 
full and complete as to exclude from the minds of your triers all doubt," he reminded the slave trader. "You are soon to be confronted with the terrible consequences of your crime." Because of this, Shipman encouraged Gordon to receive counsel from "ministers of religion, and let your repentance be as thorough and humble as your crime was great." He emphasized, "Do not attempt to hide its enormity from yourself; think of the cruelty and wickedness of seizing nearly a thousand fellow beings, who never did you harm ... Remember that you showed mercy to none." God, Shipman instructed Gordon, showed mercy to all, however. "Do not flatter yourself that because they belonged to a different race from yourself that your guilt is therefore lessened. Rather fear that it is increased," he asserted. "In the just and generous heart the humble and the weak inspire and call for pity and forbearance, and as you are soon to pass into the presence of that God of the black man as well as the white man, who is no respecter of persons, do not indulge for a moment the thought that he hears with indifference the cry of humblest of his children." Shipman sentenced Gordon to be hanged on February 7, 1862. ${ }^{241}$

Although the United States had convicted its first slave trader for piracy, Gordon was not concerned, adamant that, as in the case of James Smith, a pardon would come. Gordon had appealed his sentenced through the courts. ${ }^{242}$ His friends and family had sent petitions across the federal government for his commutation. And the Supreme Court denied their petitions for writs of either prohibition or certiorari, asserting that the court had no appellate jurisdiction in the case. Once Gordon's death warrant had, moreover, "passed out of the hands of the court, and the warrant is in the hands of the marshal commanding him to execute the judgment of the court," Chief Justice Taney held, the judicial system could do no more. ${ }^{243}$ The executive branch offered

\footnotetext{
241 "The Slave Trade: Captain Gordon, of the Slave Ship Erie, Sentenced to be Hung on the 7th February," New York Herald, December 1, 1861.

${ }^{242}$ United States v. Gordon, 25 F. Cas. 1364 (C.C.S.D.N.Y. 1861).

${ }^{243}$ Ex parte Gordon, 66 U.S. 503-505 (1861).
} 
his only route for hope. With President Lincoln already having rejected the requests of convicted slave trader and his supporters, Gordon nevertheless waited, futilely, for the president to alter his destiny.

By midnight on Friday, February 21, 1862, no word had come signaling any change of heart on the part of the president. Wanting to end his life on his own terms, Gordon attempted suicide by strychnine shortly after three o'clock that morning. The prison's physicians were quickly called and had, by ten o'clock, revived him. Assured to be alive, his life could now be ended by the authority of the federal government. But Gordon was barely conscious. The marshals had, in the intervening two hours, poured liquor into him to the point of total drunkenness. "The man was not sober," Harper's Weekly reported, "that is, so powerful had been the effect of the poison that, in order to keep him alive till the necessary moment, they had been obliged to give him whisky enough to make an ordinary man drunk three times over." When the time came, the inebriated Gordon was lifted onto a chair outside his cell, where Lincoln's February 4 order was read to him. Hoisted to his feet by two marshals, he was marched to the prison yard, heavily supported by his escorts. Reaching the gallows, a hood was placed over his head, and the noose was put around his neck, adjusted and synched to the proper place and fit. Then, as quickly as the process began, Gordon fell four feet, suspended only by his neck. His body's weight caused only the noise of a gruesome thud when it reached the end of the tether. "The body swayed hither and thither for a few moments, and all was quiet. No twitchings, no convulsions, no throes, no agonies. His legs opened once, but closed again, and he hung a lump of dishonored clay." After months of frenzied efforts trying to stop his execution, Gordon's trip to the gallows spanned all of a half an hour. ${ }^{244}$

244 “The Execution of Gordon," Harper's Weekly, 150; Soodalter, Hanging Captain Gordon, 224-225. 
The diarist George Templeton Strong reflected on Gordon's execution the next day. "Veré dignum et justum est, æquum et salutare," he declared. "It is truly dignified and just, right and salutary." He noted the countless petitions that swarmed Lincoln prior to the event and commended his "firmness." Strong remarked how "pitiful" Gordon's "exit" from the world had been, mentioning his suicide attempt and drunkenness before the criminal's demise. He also looked abroad, considering how the United States' execution of a slave trader might be seen by the "pharisaical shop-keepers \& bag-men of England." From all this, he drew a pointed conclusion: "Vivat Lex — and may it promptly exterminate every man who imports niggers into this Continent." ${ }^{245}$ The law, codified forty years before, had finally prevailed.

The foundations for US slave-trade suppression were laid long before Gordon's execution. The forfeitures of slave ships had formed the basis for the steady accumulation of precedent, which would allow the judicial system to execute Gordon without question. Beginning in the 1820 s, when a slew of cases was brought before federal courts at all levels, the slave trade was consistently taken to court. Despite declining numbers of appellate cases in the 1830s, the US government still took slavers to court throughout the decade, adding to the example set ten years earlier. But, with the Amistad case at the dawn of the 1840s and the Webster-Ashburton Treaty two years later, the volume of cases noticeably increased. But these cases during the 1840s and 1850s built on the models founded in the preceding two decades. On the Civil War's eve, the slave trade's illegality, despite having been enshrined in law forty years earlier, was cemented in judicial precedent.

Gordon's execution in February 1862 stands as a symbolic end to the antebellum period's sustained legal efforts at slave-trade suppression. Certainly, his death coincided with the entry of

\footnotetext{
${ }^{245}$ George Templeton Strong, February 22, 1862, George Templeton Strong Diary, vol. 3, p. 410, New York Historical Society Museum \& Library.
} 
a Republican administration - the empowered manifestation of antislavery-into the executive branch and the disintegration of the antebellum federal union, along with its accompanying limitations on peacetime federal action against slavery. But James I. Roosevelt had called on forty years of steady prosecution against slave trading property and plea deals for lesser offenses when he indicted Gordon for a capital offense only to start the bargaining process. Precedent in the Smith case showed that, if convicted, the President would intervene, either pardoning Gordon or, at the very least, commuting his sentence. Despite this, Edward Delafield Smith, Lincoln's prosecutor for the Southern District of New York, proceeded on that indictment. He tried Gordon to the fullest extent of the law knowing that the change in government meant the slave trader could not escape execution if convicted. By 1862, the United States had reached a position from which the execution of a slave trader could be conducted as explicitly stated in the law.

The repeated prosecution of slave traders marked the antebellum period. Regardless of the degree to which these prosecutions were successful, that they took place at all is revealing. Examining cases involving violations of the slave-trade laws complicates the image presented by Don E. Fehrenbacher of a federal government that passively allowed, if not encouraged, the Slave Power to steer its policy. Looking at the US government in macro perspective, Fehrenbacher charted the growing hold that slaveholders gained across the antebellum period. But he ignored that the lower echelons of the federal government were undermining the strength of the slave trade by confiscating the vessels on which traders trafficked human beings. It was through the unmemorable processes of admiralty law that antislavery-minded attorneys brought the powers of the federal government to bear against slave traders, recalling the methods of an earlier generation of abolitionism while laying the foundations for a later time, when the law could be fully executed. Despite decisions made at higher levels of government, these 
prosecutions did occur, and they ultimately limited the scope of slavery. By sanctioning the tools by which slave traders conducted their illicit traffic of people, these cases helped minimize the number of Africans forced into bondage and ensured that slavery would exist only within the borders of those jurisdictions in which it was already lawful. In the process, they showed that freedom reigned internationally. Respecting the slave trade, the United States was not a consistently slaveholding republic; it was an abolitionist one. Throughout the antebellum period, therefore, the federal court system served as the means - to use McCarthy's and Stauffer's term — by which antislavery advocates could assault the slave trade. Exactly who those opponents of the slave trade were, however, highlights the limitations of the historiographical definition and character of abolitionism. 


\section{CHAPTER III: CHARACTER: THE AMERICAN COLONIZATION SOCIETY,}

\section{ABOLITIONISM, AND “THE GREAT SAFETY VALVE OF THIS UNION!”}

"You well know, my dear Sir, how faithfully I labored ... to bring back the Society to its Constitutional and neutral ground respecting Slavery," wrote wealthy, antislavery-minded New Yorker Gerrit Smith to Ralph Randolph Gurley, secretary of the American Colonization Society (ACS), in November 1835. "The ineffectualness of these efferts [sic]," Smith declared, "is manifest in fact, that the Society is now, and has been for some time, far more interested in the question of slavery, than in the work of Colonization - in the demolition of the Anti-Slavery Society, than in the building up of its Colony." ${ }^{246}$ To Smith, the colonization movement had strayed into an issue where it did not belong. Colonization, a fundamentally abolitionist idea which aimed to provide an outlet for emancipated slaves and to cut off the transatlantic slave trade at its source, had become distracted by the internal politics of antislavery. An idea that continued early abolitionists' interest in suppressing the international slave trade, colonization seemed, even when working within its "Constitutional" objects, out of step with the broader abolition movement. Smith's critique nevertheless raises an important question as to the ACS's place in the story of antebellum abolition.

By the mid-1830s, an irreconcilable feud had emerged between proponents of colonization and supporters of immediatism, who had established the first national antislavery organization, the American Anti-Slavery Society, in 1833. With few visible successes, their numbers shrinking, and their finances desperately strained, colonizationists struggled to persuade the public of their plan's viability. The departure of so many wealthy, high-profile donors, like Gerrit Smith, within such a short span of time has led several historians to conclude that, by

\footnotetext{
${ }^{246}$ Gerrit Smith to Ralph Randolph Gurley, November 24, 1835, in "Gerrit Smith, Esq.," African Repository and Colonial Journal, January 1836, 36-37.
} 
1840, the ACS was obsolete - philosophically antiquated and financially impracticable. As growing numbers of antislavery advocates moved away from the gradualist, legalistic approaches that characterized the post-Revolutionary period and instead embraced calls for slavery's immediate end, increasingly fewer abolition-minded individuals saw colonization as a feasible, let alone acceptable, undertaking. The ACS had suffered from this change in antislavery sentiment. In the decade since he had first become involved in the colonization movement, Smith had emerged as the ACS's most notable benefactor. A landowner from Upstate New York, Smith had played an important role in the establishment and early successes of the New-York State Colonization Society, which formed in $1829 .{ }^{247}$ Involved with the national society since 1826 , Smith had devised two separate schemes to rescue the national society's precarious financial situation. One, which became known as the "Gerrit Smith Plan," aimed to raise $\$ 100,000$ on the society's behalf over ten years through one hundred of his most affluent friends each pledging annual contributions of $\$ 100 .{ }^{248}$ In another, in 1834 , Smith more urgently offered $\$ 5,000$ if the nation's wealthiest colonizationists in turn provided $\$ 45,000 .{ }^{249}$ Yet the society continued to falter.

But, by 1835 , Smith saw that abolitionism was decidedly moving away from colonization. A professed believer in the necessity of slavery's ultimate destruction, Smith's views had long resembled those of other colonizationists, holding that the presence of free

\footnotetext{
${ }^{247}$ African Colonization: Proceedings, on the Formation of the New-York State Colonization Society; Together with an Address to the Public, from the Managers Thereof (Albany, NY, 1829), 19-22; African Colonization: Proceedings of the New-York State Colonization Society, on Its Second Anniversary; Together with an Address to the Public, from the Managers Thereof (Albany, NY, 1831), 25; "Reports of Agents," African Repository, May $1832,80-81$. Smith was named a vice president of the state society at the organization's founding meeting in 1828. The agent of the New York state society, Lucius H. Clark, attributed the passage of a memorial through the state legislature to Gerrit Smith's efforts.

248 "Eminent Liberality," African Repository, December 1827, 318-319; "The Generous Scheme Promoted," African Repository, March 1828, 30-31.

${ }^{249}$ P. J. Staudenraus, The African Colonization Movement, 1816-1865 (New York: Columbia Univ. Press, 1961), 224.
} 
African Americans was the foremost deterrent to abolition and, therefore, their emigration was the best path to total emancipation. ${ }^{250}$ After a decade of working with the society, however, Smith began to see the colonization movement as stifling the attainment of abolition. Increasingly open to immediatist ideas, in October 1835 , Smith attended a meeting of the Garrisonian New York State Anti-Slavery Society in Utica, only twenty-five miles from his home in Peterboro. When a mob of three hundred people forced their way into the church in which the convention was being held and drove the one-thousand-person convention from the town, Smith invited the abolitionists to reconvene at his home. There, despite his years of fervent support of colonization, he declared, "the great principles of your society have ever been my principles ... I feel it to be not only my duty, but my privilege and pleasure, to identify myself with you, as far as I conscientiously can, and to expose my property, and reputation, and life, to the same dangers which threaten yours." Smith felt "obliged to become a member."251

In January 1836, the ACS entered its fourth year of crisis. Approaching its twentieth anniversary, the society had, since 1832 , hemorrhaged members and, in turn, a vital fundraising tool through which it could carry out its mission. Publishing Smith's letter in its January issue, the ACS's monthly publication, the African Repository and Colonial Journal, expressed mild regret at Smith's "defection" but asserted that the society had "adhered strictly to its constitutional objects." It continued, "we might easily show ... that the Anti-Slavery Societies

\footnotetext{
${ }^{250}$ Proceedings, on the Formation of the New-York State Colonization Society, 21. At the first meeting of the New York state society, Smith articulated an abolitionist position. While he did not explicitly state that slavery should be eradicated, he implied that the presence of free blacks in the United States was preventing slaveholders - whom he believed were acutely aware of and grappling with slavery's evils - from freeing their slaves. "Our southern slaveholders are as kind-hearted and as generous men as we are, and they deplore the evils of slavery, for which they are no more chargeable than ourselves, as much as we do. The owners of thousands of slaves are now impatient to emancipate them; but cannot do so consistently with the laws under which they live, nor consistently with kindness to their slaves, until a way is provided for their removal."

${ }^{251}$ Defensor [William Thomas], The Enemies of the Constitution Discovered, or, An Inquiry into the Origin and Tendency of Popular Violence. Containing a Complete and Circumstantial Account of the Unlawful Proceedings at the City of Utica [...] (New York, 1835), 77-81, 85-87, 158. Speech of Smith is provided in appendix on page 158.
} 
have, from their origin to the present time, waged a war of extermination against the Colonization Society." Regardless, "even had it adopted, as it has not done, the line of conduct imputed to it by Mr. S. [Smith], it would only have exercised the legitimate right of self-defence, whatever might be thought of the policy of thus acting." 252 The ACS saw Smith's critique as merely one more in a long line of unjustifiably maligning attacks against the society and hoped that its members would see it in much the same way. But the audience to which the African Repository directed this claim was growing smaller by the day. Among abolitionists, the ACS was no longer a legitimate route to slavery's eradication in the United States. Examining its position as a means to the slave trade's suppression, however, reveals a more nuanced portrait of colonization in the larger story of abolitionism.

Historians have noted the rise of Garrisonianism as a clear demarcation in the chronology of antislavery, separating Revolutionary-era gradualism from antebellum immediatism. Richard S. Newman demonstrated two distinct periods in the history of abolitionism, distinguished by tactical differences. While earlier antislavery advocates pursued government action to stamp out slavery slowly, the 1830s saw a shift toward Garrison's emotionally based calls for the swift abolition of a moral evil, according to Newman. ${ }^{253}$ As the voices of early republican gradualism faded into obscurity, submerged by the volume of immediatist fervor, so too did the popularity of gradualist schemes such as colonization. Drawing proslavery accusations from immediatists while still trying to work with Southern slaveholders, the colonization movement embodied the transition between eras of abolitionism, as advocates of the slave's cause navigated the multitude of ways to grapple with the increasingly divisive sectional issue of slavery.

\footnotetext{
252 “Gerrit Smith, Esq.," 35.

${ }^{253}$ Richard S. Newman, The Transformation of American Abolitionism: Fighting Slavery in the Early Republic (Chapel Hill: Univ. of North Carolina Press, 2002), 2-6.
} 
The historiography of colonization has largely embraced the immediatist critique that contemporarily emerged during the antebellum debate over colonization. Nowhere has this been more prominent than in discussions of colonizationists' motivations. Racial prejudice, common within even the most ardent antislavery circles of the nineteenth century, has lingered as one of the most frequent criticisms of the colonization movement, particularly in the wake of the Civil Rights Movement. As early as 1832, William Lloyd Garrison accused colonizationists of acting out of racial bias, "persecuting the blacks even unto a strange country, and verily believing they are doing God service," rather than accepting that the United States was African Americans' “only legitimate home."254

Newman as well as other recent historians of abolitionism such as R. J. M. Blackett and Manisha Sinha have carried the immediatist assessment into the present, pointing to the centrality of African Americans in the transatlantic antislavery movement and their nearly wholesale rejection of colonization. Focusing on the ACS's origins, Douglas R. Egerton focused on the role of Charles Fenton Mercer in the organization's founding. By naming Mercer-a class-obsessed, slaveholding Southerner who desired to create a controlled environment for free African Americans, whom he believed to be a hopelessly inferior group - as colonization's originator, Egerton questioned the organization's abolitionist character. Each of these historians showed that the ACS was a racist organization, which both recognized that racial prejudice existed in the United States but had no intention of confronting the problem. As Blackett explained, "The ACS contended that the problem of prejudice in the North could be solved by providing blacks with a country of their own, an environment in which racism could not

\footnotetext{
${ }^{254}$ William Lloyd Garrison, Thoughts on African Colonization: Or An Impartial Exhibition of the Doctrines,
} Principles, and Purposes of the American Colonization Society [...] (Boston, 1832), 2. 
exist." ${ }^{255}$ More harshly, in The African Colonization Movement-one of the few monographs written on the organization-P. J. Staudenraus suggested that colonizationists believed the presence of African Americans was a greater "social 'evil"” than slavery itself. 256

The politics of colonization have similarly been deemed unsuccessful and ideologically hollow. In a 1979 article, David M. Streifford studied the rhetorical role of republican ideology in the colonization movement. While slavery was not thought to contradict the republican system, it permanently cast African Americans into an inferior class, making social stratification and wealth inequality endemic. Through this, class became racially specific, and notions of equitable wealth distribution assumed the hallmarks of racial homogeneity. Although they sectionally tailored their appeals - characterizing their efforts as humane in the North and respectful of property rights in the South—colonizationists used republicanism, Streifford argued, in an attempt to garner support for their work. Streifford echoed Smith's critique of an immediatist-obsessed ACS. As the antebellum period progressed and sectional interests became more divided, colonizationists focused more heavily on attacking Garrisonian abolitionism than on expatriating African Americans to Liberia. ${ }^{257}$ More recently, Eric Burin and Sharla M. Fett have similarly suggested that colonizationists used slave-trade suppression as a self-serving "tool with which to pry open the federal coffers." 258 In the literature, therefore, colonization has emerged as the self-interested opportunist of antislavery politics.

\footnotetext{
${ }^{255}$ Newman, The Transformation of American Abolitionism, 6-8; R. J. M. Blackett, Building an Antislavery Wall: Black Americans in the Atlantic Abolitionist Movement, 1830-1860 (Ithaca, NY: Cornell Univ. Press, 1983), 47-49; Manisha Sinha, The Slave's Cause: A History of Abolition (New Haven, CT: Yale Univ. Press, 2016), 240-242; Douglas R. Egerton, "Its Origin Is Not a Little Curious': A New Look at the American Colonization Society," Journal of the Early Republic 5, no. 4 (Winter 1985): 470, https://www.jstor.org/stable/3123062. 256 Staudenraus, The African Colonization Movement, vii-viii.

${ }^{257}$ David M. Streifford, "The American Colonization Society: An Application of Republican Ideology to Early Antebellum Reform,” Journal of Southern History 45, no. 2 (May 1979): 202-214, https://www.jstor.org/stable/2208152.

${ }^{258}$ Eric Burin, "The Slave Trade Act of 1819: A New Look at the Colonization and the Politics of Slavery," American Nineteenth Century History 13, no. 1 (March 2012), 6, http://dx.doi.org/10.1080/14664658.2012.681940;
} 
But Burin showed in his Slavery and the Peculiar Solution that the ACS was, fundamentally, an abolitionist organization with significant political implications. Burin accepted Mercer's role in the ACS's founding and granted that emigration to Liberia was consistently low. ${ }^{259}$ But he argued that, despite being rooted in racism, colonization was not an innately proslavery ideology, as immediatists suggested. Although they thought African Americans suffered a degraded condition in the United States, colonizationists thought that, in Africa, "outside the canopy of prejudice," black Americans would thrive. Prejudice could not be corrected domestically, but it would not be a barrier abroad. It was because of colonizationists' desire to elevate the status of free African Americans, according to Burin, that proslavery politicians prevented the ACS from obtaining federal funding for emigration to Liberia. ${ }^{260}$ Regardless of the numbers, with each emigration, the ACS undermined slavery. ${ }^{261}$

Connecting the ACS to the gradualist Pennsylvania Abolition Society, moreover, Beverly C. Tomek contended that colonization bridged the two generations of abolitionism established by Newman. Importantly, Tomek's portrait stressed the complexity of antislavery activism. Colonizationists were gradualists, seeing the scheme as a "logical corollary" to slavery's eventual destruction in the United States. Comprised of both politically focused activists of the gradualist vein and reform-minded humanitarians who came to dominate immediatist abolitionism, colonization was a broad movement, whose belief in a long, sustained assault against slavery made it no less abolitionist. The racism on which previous historians had focused to discount colonization as an abolitionist idea, furthermore, did not jeopardize its antislavery

\footnotetext{
Sharla M. Fett, Recaptured Africans: Surviving Slave Ships, Detention, and Dislocation in the Final Years of the Slave Trade (Chapel Hill: Univ. of North Carolina Press, 2017), 25.

${ }^{259}$ Eric Burin, Slavery and the Peculiar Solution: A History of the American Colonization Society (Gainesville: Univ. of Florida Press, 2005), 5, 13-14.

${ }^{260}$ Burin, Slavery and the Peculiar Solution, 21-22.

${ }^{261}$ Burin, Slavery and the Peculiar Solution, 5.
} 
integrity. One ... area in which terminology needs clarification,” Tomek explained, "involves a general tendency among some social historians to see 'antislavery' as always benevolent." But, she continued, “"antislavery' can take on a selfish, even racist, meaning."262

When taking historical figures at their word, the historian moves at his or her own peril. The carefully constructed, persuasively minded rhetoric of a past individual or groupparticularly when the context in which that rhetoric was born was as contentious as antebellum discussions over slavery and abolition — demands skepticism. Yet, in examining the American Colonization Society, this skepticism has perhaps failed, or at least misled, historians. Wielding too narrow a definition and too simplistic a view of abolitionism, the historiography has looked past the consistent, coherent appeal that colonizationists articulated from the movement's founding and adjudged it hollow in meaning. But colonization was an abolitionist movement that specifically addressed the suppression of the transatlantic slave trade. Through a colony on the African coast, colonizationists aimed to support the federal government's efforts at slave-trade suppression, shutting off slave traders' access to the African interior and providing harbors for warships patrolling against the slave trade. At annual meeting after annual meeting throughout the antebellum period and during the Civil War, colonizationists painted the emigration of African Americans to Africa as a foundational step toward the solution of the republic's existential problem: slavery. There were a multitude of approaches to antislavery, each created and advocated by fallible human beings bound within the constraints of their time and place. Regardless of the motivation, scheme, or timeframe, agitation against slavery must be considered as such. The abolitionist character of colonization, particularly regarding the slave trade's suppression, must not be ignored.

\footnotetext{
262 Beverly C. Tomek, Colonization and Its Discontents: Emancipation, Emigration and Antislavery in Antebellum Pennsylvania (New York: New York Univ. Press, 2011), 3, https://doi.org/10.18574/nyu/9780814783481.001.0001.
} 
As colonizationist Joseph R. Ingersoll explained at the annual ACS convention in January 1849 , the organization hoped to solve several problems at once. Colonization, he claimed, offered African Americans the "opportunity to escape from a country where their condition is the most unhappy" and white Americans "an opportunity to repair in some small degree the breaches which we have made upon their race for centuries past; and to offer some slight atonement for the wrongs which we have done them." The task at hand was daunting and of paramount importance. He declared, "We say not too much when we speak of Colonization as the great safety valve of this Union!"263 Colonization, he believed, was essential for abolition.

Slavery had lingered as a blemish upon the United States' revolutionary principles since the nation's inception. "Now is the time," declared Quaker David Cooper in an anonymously published 1783 pamphlet, "to demonstrate to Europe, to the whole world, that America was in earnest, and meant what she said, when, with peculiar energy, and unanswerable reasoning, she plead [sic] the cause of human nature, and with undaunted firmness insisted, that all mankind came from the hand of their Creator equally free." With its newly found independence from Great Britain, the American colonies faced a concerning dilemma over slavery that, as Cooper highlighted, posed the potential to undermine the new nation's most treasured principles. Although independent, the thirteen colonies had not extended liberty to all people living within their borders, and, to those Americans who detested slavery, the presence of enslaved African Americans stood as a stain on the nation's republican character. Cooper continued, "Let not the

\footnotetext{
${ }^{263}$ Joseph R. Ingersoll, address to annual meeting, January 1849, Thirty-Second Annual Report of the American Colonization Society, 29, in Annual Reports of the American Society for Colonizing the Free People of Colour of the United States, vol. 21-33, bk. 3, 1837-1850 (New York: Negro Universities Press, 1969). The annual reports of the ACS were compiled and republished using facsimiles of original reports in 1969 by the Negro Universities Press over seven books, with each containing ten years of reports. Whenever annual reports are cited in this paper, it is to these compilations that reference is made. Because, however, no pagination was made outside that of the original annual reports, citations are hereafter made to individual annual reports, with reference added as to year and notation made to which volume and book reprint may be found.
} 
world have an opportunity to charge her conduct with a contradiction to her solemn and often repeated declarations; or to say that her sons are not real friends to freedom."264 To Cooper, whether the world would view the republican system that emerged from the American Revolution as sincere required slavery's abolition.

Published as America's thirteen colonies, recently divorced from Great Britain, charted their own course, Cooper's pamphlet represents a clear assertion of Revolutionary-era antislavery, which deliberately linked the United States' founding principles to the obvious contradiction of domestic slavery. Undoubtedly, this contradiction weighed heavily on the minds of antislavery advocates in the years after the Revolution. Driven by Revolutionary republican sentiments along with religious beliefs, ${ }^{265}$ these early advocates established "abolitionist" societies across the North, which pushed local legislatures to enact laws leading to gradual emancipation. ${ }^{266}$ Their efforts were not limited, however, within the states. Rather, these abolitionist societies also emphasized the closure of the foreign slave trade as a tool to fulfilling

${ }^{264}$ David Cooper, A Serious Address to the Rulers of America, on the Inconsistency of Their Conduct Respecting Slavery (London, 1783), ed. Rebecca Miller, in Early American Abolitionists: A Collection of Anti-Slavery Writings, 1760 - 1820, ed. James G. Basker, Justine Ahlstrom, Kathleen Barry, Siobhan Phinney, Nicole Seary, Sandra Trenholm, and Thorin Tritter (New York: Gilder Lehrman Institute of American History, 2005), 61.

${ }^{265}$ Filled with scriptural justification and appeals to morality, Cooper's writing recalls the antislavery arguments of pre-Revolution America. Along this line, it draws a distinction between the cruelties of domestic slavery and the Atlantic slave trade. Much like the writings of prominent pre-Revolution abolitionist Anthony Benezet, Cooper distinguishes the traffic of enslaved Africans across the Atlantic as uniquely vile. For both examples of the emphasis on Christian ethics and, in particular, the slave trade, see Anthony Benezet, Observations on the Inslaving, Importing and Purchasing of Negroes (Germantown, PA, 1760), ed. Thomas Wolf, in Basker et al., Early American Abolitionists, 9-15; Benezet, Notes on the Slave Trade (n.p., 1781), ed. Thomas Wolf, in Basker et al., Early American Abolitionists, 24-28. A contemporary of Benezet, Cooper had written against slavery and the slave trade as early as 1772. Cooper, A Mite Cast into the Treasury: Or, Observations on Slave-Keeping (Philadelphia, 1772), ed. Kristin DeBusk, in Basker et al., Early American Abolitionists, 37-49. Cooper even goes so far as to call on anyone who approves of the trade to "cease to boast the Christian name." Cooper, A Serious Address, 66.

${ }^{266}$ The Pennsylvania Abolition Society, begun in 1775, and its state's 1780 Act for the Gradual Abolition of Slavery are the classic examples of this shift from simple antislavery to abolitionism. See The Constitution of the Pennsylvania Society, for Promoting the Abolition of Slavery (Philadelphia, 1787), ed. Sam Rosenfeld, in Basker et al., Early American Abolitionists, 87-91, 93-98. 
the Revolution's principles; they saw abroad a crucial answer to the problem of slavery and a potential first step toward nationwide emancipation. ${ }^{267}$

Of course, to identify the motivations behind the 1808 ban on the importation of slaves as purely the result of republicanism ignores the themes of international abolitionism.

Conversations on the suppression of the external slave trade connected American antislavery advocates to their counterparts across the Atlantic. In Britain and on the Continent, abolitionists devoted considerable attention to the slave trade, although, by the time that the United States entered its antebellum period, this had transformed into a concern over free labor more than the earlier moral motivations of Granville Sharp and William Wilberforce. ${ }^{268}$ Nevertheless, the slave trade was a priority of international abolitionism. While republicanism may have added greater urgency to the slave trade's closure, the United States' constitutional promise to suppress the slave trade was, at its root, abolitionist in character.

From its inception, the American Colonization Society considered itself an abolitionist organization in the same vein as those across the Atlantic. ACS members revered the work of early English abolitionists, particularly those involved in the establishment of Sierra Leone, praising their efforts to eliminate the slave trade and improve the lives of those affected by slavery. Calling on the American public for support, the ACS cited Thomas Clarkson's writings on the slave trade as evidence of the need for Christian intervention. ${ }^{269}$ As ACS agents scoured the West African coast for land on which to build a colony, they first sought the advice and

\footnotetext{
${ }^{267}$ Jonathan Edwards, The Injustice and Impolicy of the Slave Trade and of the Slavery of the Africans [...] A Sermon ([New Haven, CT?], 1791), ed. Sarah Gamertsfelder, in Basker et al., Early American Abolitionists, 161.

${ }^{268}$ Seymour Drescher, Abolition: A History of Slavery and Antislavery (New York: Cambridge Univ. Press, 2009), $278-281$.

${ }^{269}$ Unsigned review of Travels in Western Africa, in the Years 1818, 19, 20, and 21, from the River Gambia, through Woolli, Bondoo, Galam, Kasson, Kaarta, and Foolidoo, to the River Niger, by William Gray, African Repository and Colonial Journal, October 1825, 228.
} 
approval of Wilberforce's African Institution, which governed Sierra Leone. ${ }^{270}$ And, when the ACS began to publish its monthly magazine, the African Repository and Colonial Journal, it provided a lengthy, eight-issue summary of a six-year-old biography on Sharp, the originator of the Sierra Leone scheme. ${ }^{271}$ Laudatory of these pioneering abolitionists, the ACS saw only continuity between its work and that of those striving to effect abolition abroad.

Colonizationists believed that slavery could not permanently exist in the United States. But, unlike the immediate abolitionists who emerged in 1820 s, their goal was not to persuade others toward broader abolition. Reflecting the views of the Founding generation, colonizationists labored under the impression that most Americans believed in the need for slavery's ultimate destruction. As Ralph Randolph Gurley explained in a defense of the ACS published in the society's magazine in April 1833, “All or nearly all Americans, cherish the desire and expectation that [slavery] will be one day abolished." ${ }^{272}$ Presupposing nationwide acceptance of a future in which slavery would be abolished, colonizationists did not believe it necessary to argue for slavery's abolition. As a result, their antislavery position, so often implicit, can be overlooked.

\footnotetext{
${ }^{270}$ First Annual Report of the American Society for Colonizing the Free People of Colour of the United States (Washington, DC, 1818), 3, in Annual Reports, vol. 1-10, bk. 1, 1818-1827.

${ }^{271}$ Unsigned review of Memoirs of the Life of Granville Sharp, Esq., Composed from His Own Manuscripts, and Other Authentic Documents in the Possession of His Family and of the African Institution, by Prince Hoare, African Repository and Colonial Journal, March 1826, 1-8; Unsigned review of Memoirs of the Life of Granville Sharp, by Prince Hoare, African Repository and Colonial Journal, April 1826, 33-40; Unsigned review of Memoirs of the Life of Granville Sharp, by Prince Hoare, African Repository and Colonial Journal, May 1826, 65-71; Unsigned review of Memoirs of the Life of Granville Sharp, by Prince Hoare, African Repository and Colonial Journal, June 1826, 101-109; Unsigned review of Memoirs of the Life of Granville Sharp, by Prince Hoare, African Repository and Colonial Journal, July 1826, 133-142; Unsigned review of Memoirs of the Life of Granville Sharp, by Prince Hoare, African Repository and Colonial Journal, August 1826, 165-172; Unsigned review of Memoirs of the Life of Granville Sharp, by Prince Hoare, African Repository and Colonial Journal, September 1826, 197-211; Unsigned review of Memoirs of the Life of Granville Sharp, by Prince Hoare, African Repository and Colonial Journal, October 1826, 229-239. Clarkson, Wilberforce, and Sharp had each, in some way, been involved in the establishment of Sierra Leone. A. P. Kup, Sierra Leone: A Concise History (New York: St. Martin's Press, 1975), 114-125, 167-169.

272 "Letter of Mr. Gurley," African Repository, April 1833, 54.
} 
More fundamentally, however, colonizationists accepted that slavery was a local institution with which outside forces could not interfere. Whether rhetorical or sincere, colonizationists embraced federalism as preventing national action against slavery. Gurley connected the ACS's mission to the Framers' vision for a national union. "In what circumstances do [the society's] supporters find themselves, while they now promote the plan of this institution?" he asked in his open letter to ACS members in 1833. "They are living under a constitutional government of twenty-four United States," he replied, "united for national purposes and the common welfare, but in other respects separate and distinct, each having the entire regulation of its own peculiar institutions and interests, and not responsible to other states $\ldots$ or to the national government, either for the character of such institutions and interests, or for the laws it may enact, or the measures it may adopt, to preserve and defend them."273

Consequently, to colonizationists, Southern cooperation was key to slavery's destruction. Rather than castigate slaveholders for participating in an evil system, colonizationists sought to build national consensus, actively working with Southerners to facilitate abolition. "Nothing can be safely and peacefully done for the direct and immediate abolition of slavery, but with the consent of the masters," Gurley declared. Colonizationists understood that, with time, the enslaved population of the United States would only grow, potentially building a progressively larger barrier to manumission. Gurley maintained that the ACS was only interested in the emigration of free African Americans, therefore respecting Southern property rights. And, playing to Southern fears of a growing free African American population that could incite violence among the enslaved, the ACS asserted that general emancipation was a greater evil than slavery itself. "The question is not whether slavery as it exists, in law and practice, in our

273 “Letter of Mr. Gurley," 52. 
southern states, be, to a great extent, a violation of the principles of Christian duty between man and man, and ought, therefore, so far as it is such violation, to be immediately modified and abolished," wrote Gurley. The question, he claimed, was "what are the means to be used by the humane and religious, to change the will of those who alone have the power, and incline them safely and wisely to remedy the evil." 274 Colonization, Gurley and other ACS members believed, was that incentive.

Because they advocated seemingly forced general emancipation, the immediatist approach was dangerous, colonizationists suggested. Gurley spurned what he called "fundamental errors of opinion," which endangered "the stability of our Union," that immediatists advocated. Included among them were that "slavery ought to be abolished by means, not acting solely through, but to a great degree against and in defiance of the will of the South" and that "the best way, if not the only way, to produce the abolition of slavery in this country, is to thunder forth denunciations against it as a flagrant crime, universally, against God and man, not to be tolerated under any modifications, for a moment, but to be destroyed at a blow." To Gurley, if this approach continued, abolitionists would create "a conflict, between the North and the South, more appalling than ever witnessed in our country" would be produced. ${ }^{275}$

By removing the factors that discouraged manumission, colonizationists saw their scheme as laying the groundwork for abolition, keeping Southern minds open to the possibility of emancipation. "The prosecution of this work is already introducing into the slaveholding States, inquiry and discussion respecting the evils of the existing structure of society there, and the possibility of abolition," wrote the Christian Spectator in March 1833. "African colonization, so far as it is successful, will bring free labor into the fairest and most extended competition with

\footnotetext{
274 “Letter of Mr. Gurley," 53-54.

275 "Letter of Mr. Gurley," 55.
} 
slave labor, and will thus make the universal abolition of slavery inevitable." ${ }^{276}$ Liberia, to Gurley, was "a blessed asylum to the free man of color, and ... the hope of the slave."277 Colonization would, its proponents believed, foster the cooperation of slaveholders, facilitating the ongoing process of emancipation.

The ACS saw slave-trade suppression as inexorably linked to the success of the Liberia colony. To them, colonization was part of a larger strategy of suppression. Colonizationists closely monitored the progress of the slave trade's conduct, ${ }^{278}$ and they presented a memorial to Congress pressing for the trade to be declared piracy prior to the enactment of the 1820 law that did so. ${ }^{279}$ In his speech at the society’s 1851 meeting, Henry Clay named the slave trade's suppression to be "another great object connected with Colonization, and only less important than that, which is to be achieved by the successful colonization of the Western Coast of Africa." Clay dismissed naval patrols as the sole means of eliminating the "most odious of all human traffic" and pointed to colonization as offering the unique advantage of creating a permanent presence along the African coast. "It has been a desideratum amongst the statemen of Europe as well as with some statesmen of our own country. They thought that the best mode of suppressing the slave trade; was by keeping up constantly squadrons on the coast of Africa, to prevent the egress of slaves," he noted. "But we have solved the great and interesting question as to the mode in which the slave trade ought to be suppressed. We have shown the most effectual and complete method by which there can be an end put to that abominable traffic, and that is by Colonization."

\footnotetext{
${ }^{276}$ Christian Spectator, “Defence of Colonization,” African Repository, June 1833, 109.

277 “Letter of Mr. Gurley," 56.

${ }^{278}$ Henry Clay, address to annual meeting, January 21, 1851, Thirty-Fourth Annual Report of the American Colonization Society, with the Proceedings of the Board of Directors and of the Society; and the Addresses Delivered at the Annual Meeting, January 21, 1851 (Washington, DC, 1851), 41, in Annual Reports, vol. 34-43, bk. 4, 1851-1860.

${ }^{279}$ The Fourth Annual Report of the American Society for Colonizing the Free People of Colour of the United States (Washington, DC, 1821), 33-34, in Annual Reports, vol. 1-10, bk. 1, 1818-1827.
} 
While he did not think that the US Navy's Africa Squadron should be disbanded, Clay suggested that colonization's effectiveness rendered a large force unnecessary. ${ }^{280}$

According to colonizationists, the areas that the ACS settled along the African coast would prevent slave traders from gaining access to the continent's interior. As Liberia grew in size, the colony carefully acquired territory in areas where the slave trade had thrived. With each acquisition, the organization's members rejoiced. The ACS's annual report for 1851 reprinted the speech of Liberian president Joseph Jenkins Roberts, who noted the recent annexation of the land surrounding the Gallinas River. What had "been for years the principal slave depot on the western coast of Africa," where the Jeune Eugénie and the seizures of the USS Cyane had been intercepted thirty years earlier, were now within the Liberian domain. With this, Roberts continued, "we see the absolute extinction of the slave-trade from Sierra Leone to Cape Palmas. That the Liberian Government is able to prevent its re-establishment, now, in the day of her strength and independence, fostered by powerful nations, we have a sufficient guaranty by what she has done at Messurado, Bassa, and Trade Town, in the time of her infancy and weakness."281 Colonizationists believed that, by colonizing the West African coastline with African American settlements, a systematic program of "civilization" would replace the illicit trade. Crucial to this was Christianization. Colonizationists argued that native West African culture had created an unstable system of intertribal wars and offered no instruction against the evils of the slave trade. Without Christian teachings, the trade would only continue. "The natives are so wedded to the traffic," reported the Liberia Herald in 1849, "it having descended to them as an heir-loom from their fathers - that they are easily roused into hostility against any and every

\footnotetext{
${ }^{280}$ Clay, address to annual meeting, Thirty-Fourth Annual Report, 41-43.

${ }^{281}$ Joseph Jenkins Roberts, May 17, 1850, quoted in Thirty-Fourth Annual Report, 22.
} 
thing they are taught to believe is arrayed against it." ${ }^{282}$ A month later, the publication concluded, "The slave trade cannot be abolished with the present war system. Colonization and religious instruction is the true method. The common people on the coast are slaves." 283 With such a religious foundation in place, colonizationists thought that Liberian colonists would encourage native Africans to turn from slave trading and toward lawful commerce.

Similarly, the ACS hoped to "improve" the lives of recaptured Africans. According to the 1819 Slave-Trade Law, the US government was to return any enslaved Africans seized in its efforts to suppress the slave trade to Africa. The ACS argued whether the law's "spirit" could be genuinely enforced "without establishing a settlement on some part of the African coast, to which captives may be sent, and where they may be sent, and where they may be received, supported and instructed in the arts of civilized life. To land them on the coast, and to leave them exposed to a repetition of those outrages which had originally destined them to a life of slavery, would seem to accomplish very imperfectly, if at all, the humane and enlarged views of the government."284

The ACS's belief in the colonization program is not to say the organization did not support the US Navy's presence along the African coast, however. Rather, colonizationists encouraged its continued existence. When the USS Cyane seized four slave ships in 1820, the society declared the voyage to "have adorned our flag with a brighter trophy than its most splendid achievements have ever won." ${ }^{285}$ And, as Congress debated withdrawing the WebsterAshburton Treaty's mandated squadron in the early 1850s, the ACS warned of the consequences.

\footnotetext{
${ }^{282}$ Liberia Herald, "Extracts from the Liberia Herald," African Repository, August 1849, 240.

${ }^{283}$ Boston Post, "The Calabar Country," African Repository, September 1849, 317.

284 The Third Annual Report of the American Society for Colonizing the Free People of Colour of the United States (Washington, DC, 1820), 6.

${ }^{285}$ Fourth Annual Report, 14.
} 
If withdrawn, "The American flag would certainly be resorted to as protection in the nefarious traffic," wrote the Liberia Herald in 1855. "And in the presence of these squadrons, the cruel trade would be resuscitated with all its horrible concomitants of wars, robbery, bloodshed and death. This would cause the utility of their continuance to be questioned by their respective governments, and they would perhaps be withdrawn also; handing over the entire coast to the tender mercies of practical slave-traders." 286

But colonizationists held that, to suppress the slave trade, required a joint program of colonization and naval patrols. "The slave trade will be more easily put down by the combined energies of Colonies and Naval force acting in concert," wrote the Liberia Herald in August 1849. "It would be eventually destroyed at a given place by a colony alone without the aid of a naval force; but the process would be tedious. A long time would be required to effect it." ${ }^{287}$

To the modern viewer, the efforts of the American Colonization Society seem, at the very least, out of step with abolitionism. Straining to distinguish themselves from the American AntiSlavery Society and other immediatist organizations and endeavoring to work with slaveholders, colonizationists emerge from the history of abolition as the embodiment of an American republic increasingly in thrall to the Slave Power. In their desire to cooperate with the South in the expulsion of black Americans, colonizationists appealed to the notions of racial hierarchy that undergirded human bondage and soothed slaveholders' consciences. Members of the ACS believed, it cannot be denied, that the United States would not survive as a multiracial republic. Having been subjugated within the confines of bondage for two centuries, black Americans would, according to their view, never reach equal status to that of whites in the Union, forever barred from broader social acceptance by the collective memory of racially specific enslavement.

\footnotetext{
${ }^{286}$ Liberia Herald, "American Squadron,” African Repository, August 1855, 251.
}

${ }^{287}$ Liberia Herald, "Extracts from the Liberia Herald," 240. 
Rather than confront racial prejudice while demolishing slavery, as immediatists urged, colonizationists preferred to remove the subjects of that prejudice. This was undoubtedly a compromise with the absolute evil that was slavery, and it was certainly one rooted in colonizationists' ideas of race.

But, regardless of the antiblack sentiments that motivated it, the ACS's abolitionist character cannot be ignored. Colonizationists worked to build a colony in Africa because they foresaw a future in which American slavery was vanquished. This was a gradualist approach, to be sure. Through Liberia, they provided an attractive alternative to those slaveholders for whom the presence of blacks after emancipation discouraged manumission. Colonizationists did not intend to spurn Southerners, for they believed that slavery's abolition meant undertaking a sustained, long-term process of emancipation that required slaveholders' cooperation. It would be in shipload after shipload, year after year, that free African Americans, they imagined, would be removed from the United States and slavery eradicated. That they strove to work with Southerners therefore does not speak to a weakness in abolitionist principles. In fact, it suggests more that colonizationists aimed to bridge the sectional divide for the sake of national union than it reveals the proslavery organization that immediatists claimed them to be. Theirs was a scheme whose philosophical framework called upon the priorities of an earlier era in the nation's history, when slavery was not the entrenched institution and point of controversy that it became in the antebellum period. Whether colonizationists actively sought to persuade Southerners to manumit their slaves is irrelevant because, to them, Liberia's existence alone was an inducement. Abolition, no matter how far in the future, was nevertheless the society's goal.

Embracing the focus of abolitionists in the post-Revolutionary era, colonizationists also recognized that abolition first required the Atlantic slave trade's destruction. Just as it served to 
entice slaveholders to manumit their slaves, Liberia, colonizationists hoped, would aid in foreclosing the slave trade. The colony would come to occupy hundreds of miles of coastline, shielding a portion of the African interior from the raids of slave traders and offering harbor to British and American warships suppressing the traffic of Africans to the Americas. A sizable portion of colonizationists' efforts were notably colonialist in nature, directed toward morally improving and proselytizing natives through the introduction of "civilized" African Americans. It cannot be denied, however, that, through this project of uplift, colonizationists fundamentally aimed to attack the slave trade, striking at what they perceived to be the causes of native complicity. While their methods bore the hallmarks of imperialism, their intentionality must not be misconstrued. For domestic slavery to die slowly, there could be no doubt that the international trade had first been totally suppressed. In viewing the presence of a colony on the African coast as valuable in its worth as a method of slave-trade suppression, therefore, the ACS underscored its continuity with traditional, gradualist approaches to abolition.

Immediate abolitionism disrupted the politics of slavery. This applied to broader abolitionism as much as it did slavery's defenders. In its wake, any organization that failed to advocate a similarly urgent call for slavery's destruction justifiably appeared inadequate, and, to this, the American Colonization Society was not immune. The subject of immediatist ire, the ACS symbolized the republic's powerlessness to deal on equal footing with the slaveholding South. But, accepting too readily immediatists' critique, the historiography has judged the society's goals as at worst proslavery and at best mired in racial prejudice, ignoring the abolitionist foundations on which it operated. The American Colonization Society was an abolitionist organization, which functioned within a pre-antebellum constitution that recalled the Framers' vision of a negotiated, measured abolition whose first step was the slave trade's 
suppression. By the antebellum period, the increasingly fervent and sectional debate over slavery brought an end to earlier hopes of gradual emancipation, and, with each last-minute compromise, a peaceful abolition faded from the realm of possibility. The ACS spanned these two eras and, consequently, challenges how modern historians have defined abolitionism. The society's continued operation, unappreciated by contemporary immediatist critics, bridged antebellum abolition to the Constitution's sole promise on slavery: the end of the Atlantic slave trade. 


\section{CONCLUSION}

Until the six bells chimed on the last dog watch on September 25, 1860, the USS

Constellation's surroundings had been placid. The sea and sky were calm, and the moonlight shone on the ocean's even surface, illuminating the horizon. But the crew of the US warship could not simply revel in the evening's tranquility, for their mission demanded perpetual readiness. ${ }^{288}$ Dispatched by the US Navy to West Africa in the summer of 1859 to fulfill the United States' obligations under the Webster-Ashburton Treaty, the Constellation was tasked at intercepting American vessels and ships fraudulently sailing under false colors engaging in the slave trade. ${ }^{289}$ Slavers exploited any opportunity to smuggle their human cargoes away from the African coast, but the favorable conditions of this peaceful autumn night offered little place to hide. Shortly after the watchman rang the six bells signaling seven o'clock, such a ship was spotted two miles off the Constellation's starboard bow. As soon as the ship in turn sighted the US warship bearing down upon it, it swiftly turned into the wind, and the Constellation followed in pursuit. ${ }^{290}$

Slowly, over the course of three hours, the Constellation gained on the ship. The US warship fired a shot in front of the ship to signal it to halt, but the unidentified vessel did not heed the warning, its crew struggling to keep the ship's distance from their pursuer. Water casks, whole hatches, and anchors were thrown overboard to lighten the ship. As one sailor aboard the Constellation recalled, "everything that was moveable" was discarded to eke out the slightest bit of extra speed. Another shot was fired in front of the vessel, again without effect. To distract

\footnotetext{
${ }^{288}$ William A. Leonard, September 25, 1860, in USS Constellation on the Dismal Coast: Willie Leonard's Journal, 1859-1861, ed. C. Herbert Gilliland (Columbia: Univ. of South Carolina Press, 2013), 147. A day is divided into seven watches, with all but two being four hours in length. The "dog-watch" is a sequence of two watches from four to eight o'clock in the evening that last two hours. Dean King, John B. Hattendorf, and J. Worth Estes, $A$ Sea of Words: A Lexicon and Companion for Patrick O'Brian's Seafaring Tales (New York: Henry Holt, 1995), 150.

${ }^{289}$ C. Herbert Gilliland, prologue to USS Constellation on the Dismal Coast, 2-3.

${ }^{290}$ Leonard, September 25, 1860, in USS Constellation on the Dismal Coast, 147.
} 
their pursuer, the vessel's crew even released one of their boats in the hope that the Constellation would stop and inspect it, thereby allowing the pursued vessel an escape. But these attempts failed. And, at around ten o'clock, the Constellation found itself within hailing distance of the other vessel, which could now be identified as the Cora. The Constellation fired a third shot. The Cora again ignored the command. To this, Captain John Nicholas of the Constellation ordered his ship's guns be lowered and fired into the Cora's masts. Tearing through the rigging of the Cora's front mast, the shot did not persuade the ship to comply. Only the threat of another blow brought about an end to the chase. ${ }^{291}$

The Constellation lowered a boat and sent a boarding party, armed with pistols and cutlasses, to inspect the ship. After a few minutes, the leader of the party hailed the Constellation, alerting Nicholas of his findings. "Constellation Ahoy!” The first lieutenant shouted. "Halloa," Nicholas responded. "We got a fine fat prize," the lieutenant declared, "chock full of darkies." For, in addition to the twenty-five men of the Cora's crew, the US sailors had discovered 705 enslaved Africans aboard. Those shackled men, women, and children were naked, desperate for food and water, wedged together below deck as if they were livestock, and terrified of what was to come, but they, along with the ship in which they had been imprisoned, was now the seized prize of a US government vessel. ${ }^{292}$

The Cora's seizure only a month before the fateful election of 1860 stands out as a curious and conspicuous contradiction to the generally accepted narrative of a United States whose foreign policy on the eve of the Civil War was the captive of slaveholders intent on spreading slavery across the globe. The ship's seizure is significant in a number of ways. For one, as the 1850 s came to a close, calls for the reopening of the slave trade abounded. That a US

\footnotetext{
${ }^{291}$ Leonard, September 25, 1860, in USS Constellation on the Dismal Coast, 147-148.

${ }^{292}$ Leonard, September 25, 1860, in USS Constellation on the Dismal Coast, 148.
} 
warship acted—and was ordered to act—in a manner explicitly foreclosing the trade's conduct suggests the futility of those appeals. Moreover, during a time when abolition was a sectional concern, that a warship of the federal government would pursue and seize a slave ship, an act with indisputable antislavery implications, is noteworthy. Finally, that the Constellation was tasked with patrolling Africa for slavers in the first place is of incredible significance, showing that the United States was not merely a passive supporter of international efforts to suppress the African slave trade; suppression of the slave trade was rather an avowed and active commitment that it vigilantly strove to pursue.

With the inauguration of the Lincoln administration in 1861, and the Civil War that followed, the federal government would pursue a harsher policy of slave-trade suppression. Although Lincoln withdrew the US Navy's Africa Squadron in the summer of 1861 to participate instead in the Southern blockade, the administration's negotiation of the Lyons-Seward Treaty with the United Kingdom in 1862 signaled the end of the United States' objection to international cooperation on slave-trade suppression on the basis of sovereignty. ${ }^{293}$ Conceding to a right to search and promising to seize ships bearing specific signs of engaging in the slave trade, the United States renewed its international commitment to the trade's destruction with greater force. ${ }^{294}$ Domestically, in a series of cases before the Supreme Court in 1864, the federal court system affirmed the legitimacy of seizures made on evidence of the slightest preparations for the slave trade. ${ }^{295}$ Under the Republican administration, freedom had become a point of national policy with international implications.

\footnotetext{
${ }^{293}$ Donald L. Canney, Africa Squadron: The U.S. Navy and the Slave Trade, 1842-1861 (Washington, DC: Potomac Books, 2006), 222; John Harris, The Last Slave Ships: New York and the End of the Middle Passage (New Haven, CT: Yale Univ. Press, 2020), 234.

${ }^{294}$ Lyons-Seward Treaty, U.S.-U.K., April 7, 1862, 12 Stat. 1225 (1862).

295 The Slavers (Kate), 69 U.S. 350 (1864); The Slavers (Sarah), 69 U.S. 366 (1864); The Slavers (Weathergage), 69 U.S. 375 (1864); The Slavers (Reindeer), 69 U.S. 383 (1864).
} 
Historians have generally ignored the international slave trade and thus skewed modern interpretation from historical reality. While the historiography of the antebellum period accepted that suppression of the international slave trade was a US diplomatic commitment, it has dismissed the sincerity with which the young republic pursued the policy. Don E. Fehrenbacher's argument has dominated the literature's view of federal policy during the period. How the United States could pursue a patently antislavery position abroad while, at home, half the states in its union held human beings in bondage reflects, after all, a curious dichotomy in the fledgling republic's position on the world stage. A nation founded and bound in union through a constitution that protected slavery's existence — and that, arguably, led to the emergence of a domestic Slave Power-implemented policies that reflected the Founders' intentions of eventual eradication by choking off the institution's supply. The proactive efforts of the US government to seize and adjudicate slavers on the high seas illustrates an antislavery position at the federal level, which could not have been adopted domestically during the antebellum period. An examination of federal cases involving seized slavers from 1820 to the Civil War reveals an antislavery-minded US government not sufficiently addressed in the historiography. These cases, in fact, lay bare a distinct portrait that joins the historiographies of US diplomacy, the coming of the Civil War, and abolitionism, rooting them in the traditional, legalistic antislavery of the nation's revolutionary founding.

From 1820 to 1862 , the United States slowly came to fulfill the promises of its constitution. After the ten-year pause in slave-trade suppression that followed the 1808 ban on the importation of slaves - largely resulting from the dispute with the United Kingdom over the rights of the independent United States - the 1820s brought about renewed abolitionist action against the trade. The Jeune Eugénie affair in 1821 vividly illustrated, however, that the young 
republic faced a conundrum over whether to join British-led efforts at suppressing the slave trade or acquiesce to its ongoing conduct. Choosing to prioritize national sovereignty, the United States allowed its courts to settle the affair, withstanding French pressure to hand over the ship without trial. The incident revealed that, while it released the ship to the French, the United States was not acting under proslavery bias, but within the early republican priority of national independence. In the forty years that followed, the courts continued to play a significant role in US suppression efforts, adjudicating the seizure of slave ships and trying slave traders for their crimes. While only one person was ever executed under the 1820 law that declared slave trading piracy, the federal courts routinely adjudicated the seizures of slave ships throughout the antebellum period, constructing and perfecting the legal mechanism for the trade's eventual abolition. Meanwhile, arising in the early republic and continuing through the Civil War, the gradualist American Colonization Society maintained a sustained assault against the slave trade and an alternate route to abolition by encouraging manumission through the repatriation of African Americans to the African coast. The society adds to the understanding of abolitionism by underscoring the true breadth of abolitionism. As these elements jointly show, the antislavery sentiment of the Revolutionary era carried into the antebellum period, as the federal government, its courts, and antislavery activists constantly drove toward the slave trade's destruction.

Overlooking the slave trade, historians' understanding of abolition has ultimately suffered. As the diplomatic, legal, and social elements of this thesis have shown, to Americans living in the antebellum period, there was no one clear route to domestic emancipation. The contradictions that pervaded US society during the era preceding the Civil War bled over into Americans' management of the slavery issue. While the federal government could police the international slave trade, its dealings with slavery at home were extremely limited. Yet, in 
seizing slave ships and returning illegally trafficked Africans back to Liberia, the United States prevented the trade from adding to the domestic enslaved population, thereby limiting slavery's expansion. This was federal action abroad that impacted the domestic institution. Similarly, an antislavery advocate, believing in the need for slavery's eventual abolition, could argue for the colonization of the West African coast with free African Americans to impede the slave trade while simultaneously arguing that emancipation could not occur until all those in bondage, along with anyone who looked like them, were removed from the United States. The colonizationist work still subverted domestic slavery. Whether direct or indirect, whether calling for prompt or slow change, and regardless of motivation, agitation against slavery was abolitionism and must not be dismissed.

Examining the slave trade reveals that gradual abolitionism did not die out with the 1830s. Rather, the techniques of the earlier generation of antislavery so intertwined with the American Revolution continued throughout the antebellum period. By focusing on the instances in which the federal government and antislavery advocates worked to combat the slave trade, this thesis has shown that notions of an entirely proslavery US government stray from historical reality. Although on the surface appearing to protect slavery, assertions of sovereignty, as evident in the Jeune Eugénie case, preserved the United States' existence until a later time when, with more power, it could work to foreclose the slave trade. With each slave ship forfeited in federal court, moreover, the United States reiterated its commitment to the freedom principle, limiting slavery's paths to survival. And, through the African American settlement of the West African coast, colonizationists strove to cut off the supply for further slaving voyages. American actions against the slave trade between 1820 and 1862 consequently show a United States travelling on the long road to emancipation. 


\section{BIBLIOGRAPHY}

\section{Primary Sources}

\section{Administrative, Legislative, and Judicial Materials}

The Alexander, 1 F. Cas. 362 (C.C.D.Mass. 1823).

The Amistad, 40 U.S. 518 (1841).

16 Annals of Congress 231 (1806). https://hdl.handle.net/2027/uc1.\$c227014.

38 Annals of Congress 13 (1821). https://hdl.handle.net/2027/uc1.\$c227036.

The Antelope, 23 U.S. 66 (1825).

The Apollon, 22 US 362 (1824).

Curranee v. McQueen, 6 F. Cas. 984 (C.C.D.Ga. n.d.).

The Emily, 22 U.S. 381 (1824).

Ex parte Gordon, 66 U.S. 503 (1861).

Executive Practices in Certain Cases, 1 Op. Att'y Gen. 505-506 (1821), https://heinonline.org/HOL/P?h=hein.agopinions/oag0001\&i=497.

The Garonne, 36 U.S. 73 (1837).

The L'Amistad, 10 F. Cas. 141 (D.Conn. 1840).

Lincoln, Abraham. "Respite of Execution for Nathaniel Gordon.” February 4, 1862, GLC00182, Gilder Lehrman Collection, Gilder Lehrman Institute of American History, New York.

The Merino, 22 U.S. 391 (1824).

The Plattsburgh, 23 U.S. 133 (1825).

Restoration of Africans Recaptured from Pirates, 1 Op. Att'y Gen. 535 (1822), https://heinonline.org/HOL/P?h=hein.agopinions/oag0001\&i=527. 
Slave Trade Prohibition Act of March 2, 1807, ch. 22, 2 Stat. 205.

https://avalon.law.yale.edu/19th_century/s1004.asp.

The St. Jago de Cuba, 22 U.S. 409 (1824).

United States v. Andrews, 24 F. Cas. 816 (C.C.S.D.N.Y. 1820).

United States v. Battiste, 24 F. Cas. 1042 (C.C.D.Mass. 1835).

United States v. Gordon, 25 F. Cas. 1364 (C.C.S.D.N.Y. 1861).

United States v. La Coste, 26 F. Cas. 826 (C.C.D.Mass. 1820).

United States v. the La Jeune Eugenie, 2 Mason 409, 26 F. Cas. 832, 840 (D. Mass., 1822).

United States v. Malebran, 26 F. Cas. 1145 (C.C.S.D.N.Y. 1820).

United States v. Smith, 27 F. Cas. 1167 (C.C.D.Mass. 1820).

\section{Memoirs, Correspondence, and Assorted Papers}

Adams, John Quincy. Argument of John Quincy Adams Before the Supreme Court of the United States, in the Case of the United States, Appellants, vs. Cinque, and Others, Africans, Captured in the Schooner Amistad [...]. New York: S. W. Benedict, 1841. https://lccn.loc.gov/11027427. . Memoirs of John Quincy Adams, Comprising Portions of His Diary from 1795 to 1848.

Edited by Charles Francis Adams, vol. 5. Philadelphia: J. B. Lippincott, 1875. https://hdl.handle.net/2027/hvd.32044013557053.

American Colonization Society. Annual Reports of the American Society for Colonizing the Free People of Colour of the United States. Vol. 1-53, bks. 1-5, 1818-1870. Washington, DC, 1818-1870. Facsimiles of original reports. New York: Negro Universities Press, 1969. 
Baldwin, Roger Sherman. Argument of Roger S. Baldwin, of New Haven, Before the Supreme Court of the United States, in the Case of the United States, Appellants, vs. Cinque, and Others, Africans of the Amistad. S. W. Benedict: New York, 1841. https://lccn.loc.gov/57051724.

Baldwin, Roger Sherman, Theodore Sedgwick, and Seth Staples. "Answer of the Proctors for the Amistad Africans," January 7, 1840. National Archives Identifier 6919561, Thomas R. Gedney v. Schooner Amistad; Case Files, 1790-1911; Records of District Courts of the United States, Record Group 21. National Archives at Boston, Waltham, MA, https://www.docsteach.org/documents/document/answer-proctors-amistad-africans

Basker, James G., Justine Ahlstrom, Kathleen Barry, Siobhan Phinney, Nicole Seary, Sandra Trenholm, and Thorin Tritter, eds. Early American Abolitionists: A Collection of AntiSlavery Writings, 1760-1820. New York: Gilder Lehrman Institute of American History, 2005.

Defensor [William Thomas]. The Enemies of the Constitution Discovered, or, An Inquiry into the Origin and Tendency of Popular Violence. Containing a Complete and Circumstantial Account of the Unlawful Proceedings at the City of Utica [...]. New York, 1835.

Gallatin, Albert. The Writings of Albert Gallatin. Edited by Henry Adams, vol. 2. Philadelphia: J. B. Lippincott, 1879. https://hdl.handle.net/2027/uc2.ark:/13960/t47p8tn6b.

Garrison, William Lloyd. Thoughts on African Colonization: Or An Impartial Exhibition of the Doctrines, Principles, and Purposes of the American Colonization Society [...]. Boston, 1832. 
Gedney, Thomas R. “Libel of Thomas R. Gedney,” August 29, 1839. National Archives Identifier 2787899, Thomas R. Gedney v. Schooner Amistad, Case Files 1790 - 1911, Records of the District Courts of the United States, 1685 - 2009, Record Group 21. National Archives, Waltham, MA. https://www.docsteach.org/documents/document/gedney-libel.

Leonard, William A. USS Constellation on the Dismal Coast: Willie Leonard's Journal, 18591861. Edited by C. Herbert Gilliland. Columbia: Univ. of South Carolina Press, 2013.

Mason, William P. A Report of the Case of the Jeune Eugénie, Determined at the Circuit Court of the United States, for the First Circuit, at Boston, December 1821. Boston: Wells \& Lilly, 1822. http://hdl.loc.gov/loc.law/llst.057.

Monroe, James. Papers. Series 1: General Correspondence, 1758-1839. Library of Congress, Washington, DC. http://hdl.loc.gov/loc.mss/ms009142.mss33217.008.

New-York State Colonization Society. African Colonization: Proceedings, on the Formation of the New-York State Colonization Society; Together with an Address to the Public, from the Managers Thereof. Albany, NY, 1829. African Colonization: Proceedings of the New-York State Colonization Society, on Its Second Anniversary; Together with an Address to the Public, from the Managers Thereof. Albany, NY, 1831.

Religious Society of Friends. A View of the Present State of the African Slave Trade. Philadelphia, 1824. https://lccn.loc.gov/18018090.

Richardson, James D., ed. A Compilation of the Messages and Papers of the Presidents. Vol. 2. New York: Bureau of National Literature, 1897. 
Story, Joseph. A Charge Delivered to the Grand Juries of the Circuit Court, at October Term, 1819, in Boston, and at November Term, 1819, in Providence, and Published at Their Unanimous Request. Boston: unidentified publisher, ca.1819. https://lccn.loc.gov/05041375.

Strong, George Templeton. George Templeton Strong Diary, vol. 3, 1854 - 1862, George Templeton Strong Diary, 1835 - 1875, New York Historical Society Museum \& Library, New York, https://digitalcollections.nyhistory.org/islandora/object/nyhs\%3Astrong.

Trenchard, Edward. "Original Document: Extract from Journal of the U.S.S. Cyane, 1820," Magazine of American History: A Monthly Illustrated Journal 30, no. 1 - 2 (July August 1893): $92-95$, https://books.google.com/books?id=U5o_AQAAMAAJ\&pg=PT2\#v=onepage\&q\&f=fals e.

Webster, Daniel. The Private Correspondence of Daniel Webster. Edited by Fletcher Webster, vol. 1. Boston: Little, Brown, 1876. https://hdl.handle.net/2027/uc2.ark:/13960/t3319s98q.

\section{Periodicals}

African Repository and Colonial Journal.

Aurora \& Franklin Gazette (Philadelphia).

Daily Commercial Bulletin (St. Louis).

Emancipator (New York).

Harper's Weekly. "The Execution of Gordon, the Slave-Trader." March 8, 1861.

Maryland Gazette (Annapolis, MD).

Liberator (Boston). 
National Intelligencer (Washington, DC).

New York Evening Post.

New York Herald.

New York Times.

New York Spectator.

New York Sun.

Niles' Weekly Register (Baltimore, MD).

Noticioso de ambos mundos (New York).

\section{Secondary Sources}

Bacon, Margaret Hope. “Quakers and Colonization.” Quaker History 95, no. 1 (Spring 2006):

26-43. https://www.jstor.org/stable/41947575.

Baker, Robert H. Prigg v. Pennsylvania: Slavery, the Supreme Court, and the Ambivalent Constitution. Lawrence: Univ. Press of Kansas, 2012.

Baggett, James Alex. The Scalawags: Southern Dissenters in the Civil War and Reconstruction. Baton Rouge: Louisiana State Univ. Press 2003.

Baptist, Edward E. The Half Has Never Been Told: Slavery and the Making of American Capitalism. New York: Basic Books, 2014.

Batterson, Sarah A. ““An Ill-Judged Piece of Business': The Failure of Slave Trade Suppression in a Slaveholding Republic.” PhD diss., Univ. of New Hampshire, 2013. ProQuest ID 1436984189.

Becker, Sven. Empire of Cotton: A Global History. New York: Vintage Books, 2014.

Bemis, Samuel Flagg. A Diplomatic History of the United States. 3rd ed. 1936; New York: Henry Holt, 1950. 
—. John Quincy Adams and the Foundations of American Foreign Policy. New York:

Alfred A. Knopf, 1949.

Benton, Lauren, and Lisa Ford. Rage for Order: The British Origins of International Law, 18001850. Cambridge, MA: Harvard Univ. Press, 2016.

Blackett, R. J. M. “Anglo-American Opposition to Liberian Colonization, 1831-1833.”

Historian 41, no. 2 (February 1979): 276-294. https://www.jstor.org/stable/24445108.

_. Building an Antislavery Wall: Black Americans in the Atlantic Abolitionist Movement, 1830-1860. Ithaca, NY: Cornell Univ. Press, 1983.

Bryant, Jonathan M. Dark Places of the Earth: The Voyage of the Slave Ship Antelope. New York: Liveright, 2015.

Burin, Eric. Slavery and the Peculiar Solution: A History of the American Colonization Society. Gainesville: Univ. Press of Florida, 2005.

_ . "Rethinking Northern White Support for the African Colonization Movement: The Pennsylvania Colonization Society as an Agent of Emancipation." Pennsylvania Magazine of History and Biography 127, no. 2 (April 2003): 197-229. https://www.jstor.org/stable/20093619.

—. "The Slave Trade Act of 1819: A New Look at the Colonization and the Politics of Slavery." American Nineteenth Century History 13, no. 1 (March 2012): 1-14. http://dx.doi.org/10.1080/14664658.2012.681940.

Burton, Ann M. "Evangelicals, Economic Warfare, and the Abolition of the Atlantic Slave Trade, 1794-1810." Anglican and Episcopal History 65, no. 2 (June 1996): 197-225.

Canney, Donald L. Africa Squadron: The U.S. Navy and the Slave Trade, 1842-1861. Washington, DC: Potomac Books, 2006. 
Carter, Ralph Donald. "Black American or African: The Response of New York City Blacks to African Colonization, 1817-1841.” PhD diss., Clark Univ., 1974. ProQuest ID 302714009.

Cover, Robert M. Justice Accused: Antislavery and the Judicial Process. New Haven, CT: Yale Univ. Press, 1975.

Davis, David Brion. In the Image of God: Religion, Moral Values, and Our Heritage of Slavery. New Haven, CT: Yale Univ. Press, 2001.

- Inhuman Bondage: The Rise and Fall of Slavery in the New World. New York: Oxford Univ. Press, 2006.

- The Problem of Slavery in the Age of Emancipation. New York: Vintage Books, 2014.

Davis, Hugh. "Northern Colonizationists and Free Blacks, 1823-1837: A Case Study of Leonard Bacon.” Journal of the Early Republic 17, no. 4 (Winter 1997): 651-675. https://www.jstor.org/stable/3124319.

Delbanco, Andrew. The War Before the War: Fugitive Slaves and the Struggle for America's Soul from the Revolution to the Civil War. New York: Penguin Books, 2018.

DeLombard, Jeannine Marie. Slavery on Trial: Law, Abolitionism, and Print Culture. Chapel Hill: Univ. of North Carolina Press, 2007.

Dew, Charles B. Apostles of Disunion: Southern Secession Commissioners and the Causes of the Civil War. 2001; Charlottesville: Univ. of Virginia Press, 2016.

Deyle, Steven. “An 'Abominable' New Trade: The Closing of the African Slave trade and the Changing Patterns of U.S. Political Power, 1808-60." William and Mary Quarterly 66, no. 4 (October 2009): 833-850. 
Doyle, Don H. The Cause of All Nations: An International History of the American Civil War. New York: Basic Books, 2015.

Drescher, Seymour. Abolition: A History of Slavery and Antislavery. New York: Cambridge Univ. Press, 2009.

Du Bois, W. E. B. Black Reconstruction in America: 1860-1880. 1935; New York: Free Press, 1998.

- The Suppression of the African Slave-Trade to the United States of America, 16381870. New York: Oxford Univ. Press, 2007.

Dyer, Justin Buckley. "Slavery and the Magna Carta in the Development of Anglo-American Constitutionalism.” PS: Political Science and Politics 43, no. 3 (July 2010): 479-482. https://www.jstor.org/stable/25699354.

Egerton, Douglas R. “'Its Origin Is Not a Little Curious': A New Look at the American Colonization Society.” Journal of the Early Republic 5, no. 4 (Winter 1985): 463-480. https://www.jstor.org/stable/3123062.

Eltis, David. Economic Growth and the Ending of the Transatlantic Slave Trade. New York: Oxford Univ. Press, 1987.

Fehrenbacher, Don E. The Slaveholding Republic: An Account of United States Government's Relations to Slavery. Edited by Ward M. McAfee. New York: Oxford Univ. Press, 2001. Fett, Sharla M. Recaptured Africans: Surviving Slave Ships, Detention, and Dislocation in the Final Years of the Slave Trade. Chapel Hill: Univ. of North Carolina Press, 2017. Finkelman, Paul. An Imperfect Union: Slavery, Federalism, and Comity. 1981; Clark, NJ: Lawbook Exchange, 2013. 
- Slavery in the Courtroom: An Annotated Bibliography of American Cases. Washington, DC: Library of Congress, 1985.

—. Supreme Injustice: Slavery in the Nation's Highest Court. Cambridge, MA: Harvard Univ. Press, 2018.

Finkenbine, Roy E. “'Who Will ... Pay for Their Sufferings?': New York Abolitionists and the Campaign to Compensate Solomon Northup." New York History 95, no. 4 (Fall 2014): 637-646. https://www.jstor.org/stable/10.2307/newyorkhist.95.4.637.

Foner, Eric. The Fiery Trial: Abraham Lincoln and American Slavery. New York: W. W. Norton, 2010.

Fry, Joseph A. Lincoln, Seward, and US Foreign Relations in the Civil War Era. Lexington: Univ. Press of Kentucky, 2019.

Gilliland, C. Herbert. Introduction to USS Constellation: On the Dismal Coast; Willie Leonard's Journal, 1859-1861, edited by C. Herbert Gilliland. Columbia: Univ. of South Carolina Press, 2013.

Gould, Eliga H. Among the Powers of the Earth: The American Revolution and the Making of a New World Empire. Cambridge, MA: Harvard Univ. Press, 2012.

Harlow, Ralph Volney. "Gerrit Smith and the John Brown Raid.” American Historical Review 38, no. 1 (October 1932): 32-60. https://www.jstor.org/stable/1838063.

Hartman, Saidiya V. Scenes of Subjection: Terror, Slavery, and Self-Making in Nineteenth Century America. New York: Oxford Univ. Press, 1997.

Hartog, Hendrik. The Trouble with Minna: A Case of Slavery and Emancipation in the Antebellum North. Chapel Hill: Univ. of North Carolina Press, 2018. 
Herring, George C. From Colony to Superpower: US Foreign Relations Since 1776. New York: Oxford Univ. Press, 2008.

Horsman, Reginald. “On to Canada: Manifest Destiny and United States Strategy in the War of 1812." Michigan Historical Review 13, no. 2 (Fall 1987): 1-24.

Howard, Warren S. American Slavers and the Federal Law: 1837-1862. Berkeley: Univ. of California Press, 1962.

Howe, Daniel Walker. What Hath God Wrought: The Transformation of America, 1815-1848. New York: Oxford Univ. Press, 2007.

Hughes, Jim. “Those Who Passed Through: Unusual Visits to Unlikely Places.” New York History 84, no. 3 (Summer 2003): 330-333. https://www.jstor.org/stable/23183372.

Huston, James L. Securing the Fruits of Labor: The American Concept of Wealth Distribution, 1765-1900. 1998; Baton Rouge: Louisiana State Univ. Press, 2015.

Hyam, Ronald. Britain's Imperial Century, 1815-1914: A Study of Empire and Expansion. New York: Palgrave MacMillan, 2002.

Anonymous. "International Norms and Politics in the Marshall Court's Slave Trade Cases," Harvard Law Review 128, no. 4 (February 2011): 1184-1205, https://www.jstor.org/stable/24643961.

Jennings, Lawrence C. French Anti-Slavery: The Movement for the Abolition of Slavery in France, 1802-1848. New York: Cambridge Univ. Press, 2000.

Johnson, Walter. River of Dark Dreams: Slavery and Empire in the Cotton Kingdom. Cambridge, MA: Belknap Press of Harvard Univ. Press, 2013.

- Soul by Soul: Life Inside the Antebellum Slave Market. Cambridge, MA: Harvard Univ. Press, 1999. 
Jones, Howard. Mutiny on the Amistad: The Saga of a Slave Revolt and Its Impact on American Abolition, Law, and Diplomacy. New York: Oxford Univ. Press, 1987.

Karp, Matthew. This Vast Southern Empire: Slaveholders at the Helm of American Foreign Policy. Cambridge, MA: Harvard Univ. Press, 2016.

Karsten, Peter. Heart Versus Head: Judge-Made Law in Nineteenth-Century America. Chapel Hill: Univ. of North Carolina Press, 1997.

Kennington, Kelly M. In the Shadow of Dred Scott: St. Louis Freedom Suits and the Legal Culture of Slavery in Antebellum America. Athens: Univ. of Georgia Press, 2017.

Kielstra, Paul Michael. The Politics of Slave Trade Suppression in Britain and France, 1814-48: Diplomacy, Morality, and Economics. New York: St. Martin's, 2000.

King, Dean, John B. Hattendorf, and J. Worth Estes. A Sea of Words: A Lexicon and Companion for Patrick O’Brian's Seafaring Tales. New York: Henry Holt, 1995.

Kup, A. P. Sierra Leone: A Concise History. New York: St. Martin's Press, 1975.

Kupperman, Karen Ordahl. The Atlantic in World History. New York: Oxford Univ. Press, 2012.

Landy, Craig A. "Society of United Irishmen Revolutionary and New-York Manumission Society Lawyer: Thomas Addis Emmett and the Irish Contributions to the Antislavery Movement in New York.” New York History 95, no. 2 (Spring 2014): 193-222. https://www.jstor.org/stable/newyorkhist.95.2.193.

Leonard, Gerald, and Saul Cornell. The Partisan Republic: Democracy, Exclusion, and the Fall of the Founders' Constitution, 1780s-1830s. New York: Cambridge Univ. Press, 2019.

Lubet, Steven. Fugitive Justice: Runaways, Rescuers, and Slavery on Trial. Cambridge, MA: Belknap Press of Harvard Univ. Press, 2010. 
Lynch, David. The Role of Circuit Courts in the Formation of United States Law in the Early Republic: Following Supreme Court Justices Washington, Livingston, Story, and Thompson. Portland, OR: Hart, 2018.

Maltz, Earl M. Slavery and the Supreme Court, 1825-1861. Lawrence: Univ. Press of Kansas, 2009.

Maris-Wolf, Ted. “'Of Blood and Treasure': Recaptive Africans and the Politics of Slave Trade Suppression." Journal of the Civil War Era 4, no. 1 (March 2014): 53-83.

Marques, Leonardo. The Contraband Slave Trade to Brazil and the Dynamics of US Participation, 1831-1856." Journal of Latin American Studies 47, no. 4 (November 2015): 659-684.

Martin, Gaston. L'Histoire de l'esclavage dans les colonies françaises. Brionne, France: Gérard Monfort, 1948.

Martinez, Jenny S. The Slave Trade and the Origins of International Human Rights Law. New York: Oxford Univ. Press, 2012.

Mason, Matthew. "Keeping Up Appearances: The International Politics of Slave Trade Abolition in the Nineteenth-Century Atlantic World." William and Mary Quarterly 66, no. 4 (October 2009): 809-832.

—. "Slavery Overshadowed: Congress Debates Prohibiting the Atlantic Slave Trade to the United States, 1806-1807." Journal of the Early Republic 20, no. 1 (Spring 2000): 5981.

McCarthy, Timothy Patrick, and John Stauffer, eds. Prophets of Protest: Reconsidering the History of American Abolitionism. New York: New Press, 2006. 
McDaniel, W. Caleb. The Problem of Democracy in the Age of Slavery: Garrisonian Abolitionists and Transatlantic Reform. Baton Rouge: Louisiana State Univ. Press, 2013.

McKivigan, John R., ed. Abolitionism and American Law. New York: Garland, 1999.

McKivigan, John R., and Madeleine L. McKivigan. “'He Stands Like Jupiter': The Autobiography of Gerrit Smith.” New York History 65, no. 2 (April 1984): 188-200. https://www.jstor.org/stable/23173232.

McNeilly, Earl E. "The United States Navy and the Suppression of the West African Slave Trade, 1819 - 1862.” PhD diss., Case Western Reserve Univ., 1973. ProQuest ID 302637917.

Miller, William Lee. “I Felt It to Be My Duty to Refuse': The President and the Slave Trader," in Lincoln Revisited: New Insights from the Lincoln Forum, ed. John Y. Simon, Harold Holzer, and Dawn Vogel, 147-168. New York: Fordham Univ. Press, 2007.

Newman, Richard S. The Transformation of American Abolitionism: Fighting Slavery in the Earlier Republic. Chapel Hill: Univ. of North Carolina Press, 2002.

Noonan, John T., Jr., The Ordeal of Recaptured Africans in the Administrations of James Monroe and John Quincy Adams. Berkeley: Univ. of California Press, 1977.

Oakes, James. Freedom National: The Destruction of Slavery in the United States, 1861-1865. New York: W. W. Norton, 2013.

- The Scorpion's Sting: Antislavery and the Coming of the Civil War. New York: W. W. Norton, 2014.

Obadele-Starks, Ernest. Freebooters and Smugglers: The Foreign Slave Trade in the United States After 1808. Fayetteville: Univ. of Arkansas Press, 2007. 
Peabody, Sue. "There Are No Slaves in France”: The Political Culture of Race and Slavery in the Ancien Régime. New York: Oxford Univ. Press, 1996.

Pétré-Grenouilleau, Olivier, ed. Abolir l'esclavage: Un réformisme à l'épreuve (France, Portugal, Suisse, XVIII $-X I X^{e}$ siècles). Rennes, France: Presses universitaires de Rennes, 2008.

Quénéhervé, David. “1808: 'Il n’est guère possible de faire des affaires en temps de guerre’; Lettre de Pierre Labatut." Généalogie et Histoire de la Caraïbe, 4. https://www.ghcaraibe.org/articles/2012-art24.pdf

Rawley, James A. "Nathaniel Gordon, the Only American Executed for Violating the Slave Trade Laws," Civil War History 39, no. 3 (September 1993): 216-224. https://doi.org/10.1353/cwh.1993.0061.

Rediker, Marcus. The Amistad Rebellion: An Atlantic Odyssey of Slavery and Freedom. New York: Penguin Books, 2012.

—. The Slave Ship: A Human History. New York: Penguin, 2008.

Rees, Siân. Sweet Waters and Bitter: The Ships That Stopped the Slave Trade. Durham: Univ. of New Hampshire Press, 2011.

Roosevelt, Theodore. The Naval War of 1812. New York, 1882. Reprinted with introduction by John Allen Gable. New York: Modern Library, 1999. Page references are to 1999 edition. Schmidt, Nelly. Abolitionnistes de l'esclavage et réformateurs des colonies: 1820-1851; analyse et documents. Paris: Karthala, 2000. 
Seaton, David. "Warts and All: How The Plattsburgh Should Change the Way We Look at the Face of Baltimore Maritime History.” Legal History Collections (2013): 1-30. https://digitalcommons.law.umaryland.edu/cgi/viewcontent.cgi? article=1044\& context=m lh_pubs.

Seifman, Eli. “A History of the New-York State Colonization Society.” PhD diss., New York Univ., 1965. ProQuest ID 302140011.

Silverstone, Scott A. Divided Union: The Politics of War in the Early American Republic. Ithaca, NY: Cornell Univ. Press, 2004.

Sinha, Manisha. The Slave's Cause: A History of Abolition. New Haven, CT: Yale Univ. Press, 2016.

Sherwood, Marika. After Abolition: Britain and the Slave Trade Since 1807. New York: I. B. Tauris, 2007.

Smallwood, Stephanie E. Saltwater Slavery: A Middle Passage from Africa to American Diaspora. Cambridge, MA: Harvard Univ. Press, 2007.

Soodalter, Ron. Hanging Captain Gordon: The Life and Trial of an American Slave Trader. New York: Atria Books, 2006.

Soulsby, Hugh G. The Right of Search and the Slave Trade in Anglo-American Relations: 18141862. Baltimore: Johns Hopkins Univ. Press, 1933.

Sparks, Randy J. "Blind Justice: The United States' Failure to Curb the Illegal Slave Trade.” Law and History Review 35, no. 1 (February 2017): 53-79.

Staudenraus, P. J. The African Colonization Movement, 1816-1865. New York: Columbia Univ. Press, 1961. 
Stein, Robert Louis. The French Slave Trade in the Eighteenth Century: An Old Regime Business. Madison: Univ. of Wisconsin Press, 1979.

Streifford, David M. "The American Colonization Society: An Application of Republican Ideology to Early Antebellum Reform.” Journal of Southern History 45, no. 2 (May 1979): 201-220. https://www.jstor.org/stable/2208152.

Tanner, E. P. "Gerrit Smith: An Interpretation." Quarterly Journal of the New York State Historical Association 5, no. 1 (January 1924): 21-39. https://www.jstor.org/stable/43554023.

Tomek, Beverly C. Colonization and Its Discontents: Emancipation, Emigration, and Antislavery in Antebellum Pennsylvania. New York: New York University Press, 2011. https://doi.org/10.18574/nyu/9780814783481.001.0001.

Van Cleve, George. "Somerset's Case and Its Antecedents in Imperial Perspective." Law and History Review 24, no. 3 (Fall 2006): 601-645. https://www.jstor.org/stable/27641404.

Vara-Dannen, Theresa C. "The Limits of White Memory: Slavery Violence, and the Amistad Incident.” Journal of American Studies 49, no. 1 (2015): 19-54. https://doi.org/10.1017/S0021875814001297.

Waldstreicher, David. Slavery's Constitution: From Revolution to Ratification. New York: Hill \& Wang, 2009.

Webb, Derek A. “The Somerset Effect: Parsing Lord Mansfield's Words on Slavery in Nineteenth Century America." Law and History Review 32, no. 3 (August 2014): 455490. https://www.jstor.org/stable/43670721.

Wilentz, Sean. No Property in Man: Slavery and Antislavery at the Nation's Founding. Cambridge, MA: Harvard Univ. Press, 2018. 
Williams, Carolyn. “'Am I Not a Man and a Brother?' 'Am I Not a Woman and a Sister?': The Trans-Atlantic Crusade Against the Slave Trade and Slavery.” Caribbean Quarterly 56, no. 1/2 (March/June 2010): 107-126.

Wise, Steven M. Though the Heavens May Fall: The Landmark Trial That Led to the Fall of Human Slavery. Cambridge, MA: Da Capo Press, 2005.

Witt, John Fabian. Lincoln's Code: The Laws of War in American History. New York: Free Press, 2012.

Wood, Gordon S. Empire of Liberty: A History of the Early Republic, 1789-1815. New York: Oxford Univ. Press, 2009.

Wright, Gavin. Slavery and American Economic Development. Baton Rouge: Louisiana State Univ. Press, 2006.

Zeuske, Michael. "Rethinking the Case of the Schooner Amistad: Contraband and Complicity After 1808/1820." Slavery \& Abolition 35, no. 1 (2015): 156-164.

http://dx.doi.org/10.1080/0144039X.2013.798173. 


\section{INTRODUCTION TO THE APPENDICES}

The following appendices comprise different aspects of the research conducted for this thesis. Each, related to the slave-trade suppression efforts discussed in the second chapter, charts: the court cases that arose during the period from 1820 to 1865 (Appendix A); the slave ships that the US Navy's Africa Squadron seized following the Webster-Ashburton Treaty (Appendix B); the US Navy’s ship presence along the West African coast from 1825 to 1860 relative to its entire fleet (Appendix C); and the British Royal Navy's ship presence along the West African coast relative to its entire fleet upon Queen Victoria's ascension to the throne in 1837 (Appendix D). Given the space constraints inherent in a master's thesis - as well as those that naturally result from using a narrative form - these appendices serve to enumerate the breadth of evidence from which the thesis's conclusions were drawn and to illustrate the variety of research techniques carried out that may not be evident within the thesis's body. Ultimately, much like the thesis itself, these appendices raise as many questions as they answer and illustrate a potentially rich field to mine in future research.

Appendices A and B aim to show the extent of federal slave-trade suppression efforts. Appendix A lists every court case found in the research process, regardless of whether the case was integrated into the thesis's body. These cases were found through searches for court reports on the Westlaw legal database using search terms related to the slave trade and federal slavetrade laws. As acknowledged and explained in footnote forty-six of the introduction, in most cases, only appeals appear in court reports. While these could well have been the only cases brought to court over the slave trade during the antebellum period, it is likely that there were far more cases than this list suggests. Similarly, Appendix B merely lists every ship seized during 
the post-Webster-Ashburton period. This table is transferred from Donald L. Canney's The Africa Squadron. No confirmation of this information has been made beyond Canney's work. Appendices $\mathrm{C}$ and D lay out the data gathered on American versus British naval commitments against the slave trade. For the US Navy, in Appendix C, ship lists from 1825, 1832, 1848, 1851, 1853, 1858, and 1860 were uploaded into Microsoft Excel from the amateur naval history website bluejacket.com, where they had already been digitally published in table form. The Navy originally published these lists throughout the antebellum period in annual books called the Register of the Commissioned Officers and Warrant Officers of the Navy of the United States. In addition to providing the duty station of every naval officer, these books listed each ship in the Navy's fleet and its present condition and location. After transferring the data from bluejacket.com, the original source was consulted in each case to confirm the information. Similarly, for the Royal Navy, the data already digitally published on naval-history.net (transcribed from the 1838 publication The Navy List, Corrected to the 20th Dec., 1837) was imported and confirmed against the original. For ships that lacked any data, Rif Winfield's British Warships in the Age of Sail, 1817-1863 (2014) was consulted. The spreadsheets were then formatted for consistency, with columns searched for situation (whether "in commission," "in ordinary," or "on the stocks") and location. The tonnage, number of ships, and guns found with each search term were tabulated and, calculating only "in commission" ships located in Africa, percentages found relative to the entire "in service" navy. A sample spreadsheet for 1848 is given for the US Navy, while, with only one year, 1837 is provided in full for the Royal Navy. 


\section{APPENDIX A: ALL SLAVE-TRADE CASES EXAMINED}

Table A-1. All federal slave-trade cases examined in study, listed chronologically

\begin{tabular}{|c|c|c|c|c|c|}
\hline Caption & $\begin{array}{c}\text { Year } \\
\text { Decided }\end{array}$ & Court & Citation & $\begin{array}{c}\text { Location of } \\
\text { Seizure }\end{array}$ & $\begin{array}{c}\text { Act(s) under } \\
\text { which suit } \\
\text { brought }\end{array}$ \\
\hline $\begin{array}{l}\text { United States } \\
\text { v. Malebran }\end{array}$ & 1820 & C.C.S.D.N.Y. & $\begin{array}{l}26 \text { F. Cas. } \\
1145\end{array}$ & Liberia & 1818 \\
\hline $\begin{array}{l}\text { United States } \\
\text { v. Andrews }\end{array}$ & 1820 & C.C.S.D.N.Y. & $\begin{array}{l}24 \text { F. Cas. } \\
815\end{array}$ & $\begin{array}{l}\text { Liberia } \\
\text { (Endymion, } \\
\text { ship) }\end{array}$ & 1800 \\
\hline $\begin{array}{l}\text { United States } \\
\text { v. La Coste }\end{array}$ & 1820 & C.C.D.Mass. & $\begin{array}{l}26 \text { F. Cas. } \\
826\end{array}$ & & 1818 \\
\hline $\begin{array}{l}\text { United States } \\
\text { v. The La } \\
\text { Jeune } \\
\text { Eugénie }\end{array}$ & 1822 & C.C.D.Mass. & $\begin{array}{l}26 \text { F. Cas. } \\
832\end{array}$ & Liberia & $\begin{array}{l}1808,1818 \\
1819,1820\end{array}$ \\
\hline $\begin{array}{l}\text { The } \\
\text { Alexander }\end{array}$ & 1823 & C.C.D.Mass. & $\begin{array}{l}1 \text { F. Cas. } \\
362\end{array}$ & & $1794,1800,1818$ \\
\hline $\begin{array}{l}\text { The Emily } \\
\text { and the } \\
\text { Caroline }\end{array}$ & 1824 & $\begin{array}{l}\text { US Supreme } \\
\text { Court (on } \\
\text { appeal from } \\
\text { C.C.S.C.) }\end{array}$ & 22 U.S. 381 & $\begin{array}{l}\text { Charleston, SC } \\
\text { (prior to } \\
\text { departure) }\end{array}$ & 1794,1808 \\
\hline $\begin{array}{l}\text { The St. Jago } \\
\text { de Cuba }\end{array}$ & 1824 & $\begin{array}{l}\text { US Supreme } \\
\text { Court (on } \\
\text { appeal from } \\
\text { C.C.Md.) }\end{array}$ & 22 U.S. 409 & $\begin{array}{l}\text { Baltimore (on } \\
\text { return from } \\
\text { Africa) }\end{array}$ & 1794,1818 \\
\hline $\begin{array}{l}\text { The Merino, } \\
\text { the } \\
\text { Constitution, } \\
\text { and the } \\
\text { Louisa }\end{array}$ & 1824 & $\begin{array}{l}\text { US Supreme } \\
\text { Court (on } \\
\text { appeal from } \\
\text { C.C.D.Al.) }\end{array}$ & 22 U.S. 391 & $\begin{array}{l}\text { Mobile, AL (en } \\
\text { route from } \\
\text { Cuba) }\end{array}$ & 1800,1818 \\
\hline $\begin{array}{l}\text { The } \\
\text { Plattsburgh }\end{array}$ & 1825 & $\begin{array}{l}\text { US Supreme } \\
\text { Court (on } \\
\text { appeal from } \\
\text { C.C.S.D.N.Y.) }\end{array}$ & 23 U.S. 133 & $\begin{array}{l}\text { Liberia (in } \\
1820 \text { ) }\end{array}$ & 1784,1800 \\
\hline $\begin{array}{l}\text { The Josefa } \\
\text { Segunda }\end{array}$ & 1825 & $\begin{array}{l}\text { US Supreme } \\
\text { Court (on } \\
\text { appeal from } \\
\text { C.C.E.D.La.) }\end{array}$ & $\begin{array}{l}23 \text { U.S. } \\
312^{\mathrm{a}}\end{array}$ & $\begin{array}{l}\text { New Orleans } \\
\text { (on return from } \\
\text { Africa) }\end{array}$ & 1808,1818 \\
\hline The Antelope & 1825 & $\begin{array}{l}\text { US Supreme } \\
\text { Court }\end{array}$ & 23 U.S. 66 & Savannah, GA & \\
\hline
\end{tabular}




\begin{tabular}{|c|c|c|c|c|c|}
\hline Caption & $\begin{array}{c}\text { Year } \\
\text { Decided }\end{array}$ & Court & Citation & $\begin{array}{c}\text { Location of } \\
\text { Seizure }\end{array}$ & $\begin{array}{c}\text { Act(s) under } \\
\text { which suit } \\
\text { brought }\end{array}$ \\
\hline $\begin{array}{l}\text { Curranee v. } \\
\text { McQueen }\end{array}$ & [1828?] & C.C.D.Ga. & $\begin{array}{l}6 \text { F. Cas. } \\
984\end{array}$ & No seizure & 1808 \\
\hline $\begin{array}{l}\text { Governor of } \\
\text { Georgia v. } \\
\text { Madrazo }\end{array}$ & 1828 & $\begin{array}{l}\text { US Supreme } \\
\text { Court (on } \\
\text { appeal from } \\
\text { C.C.D.Ga. }\end{array}$ & 26 U.S. 110 & & 1808 \\
\hline $\begin{array}{l}\text { United States } \\
\text { v. Preston }\end{array}$ & 1830 & $\begin{array}{l}\text { US Supreme } \\
\text { Court (on } \\
\text { appeal from } \\
\text { C.C.E.D.La. }\end{array}$ & 28 U.S. 57 & New Orleans & 1808 \\
\hline $\begin{array}{l}\text { Ex parte } \\
\text { Madrazzo }^{\mathrm{c}}\end{array}$ & 1833 & $\begin{array}{l}\text { US Supreme } \\
\text { Court (on } \\
\text { appeal from } \\
\text { C.C.D.Ga.) }\end{array}$ & 32 U.S. 627 & & \\
\hline $\begin{array}{l}\text { United States } \\
\text { v. Battiste }\end{array}$ & 1835 & C.C.D.Mass. & $\begin{array}{l}24 \mathrm{~F} . \text { Cas. } \\
1042\end{array}$ & & 1800,1820 \\
\hline The Garonne & 1837 & $\begin{array}{l}\text { US Supreme } \\
\text { Court (on } \\
\text { appeal from } \\
\text { D.C.E.D.La.) }\end{array}$ & 36 U.S. 73 & $\begin{array}{l}\text { New Orleans } \\
\text { (on return from } \\
\text { Le Havre, } \\
\text { France) }\end{array}$ & 1808,1818 \\
\hline $\begin{array}{l}\text { Emerson's } \\
\text { Heirs v. Hall }\end{array}$ & 1839 & $\begin{array}{l}\text { US Supreme } \\
\text { Court }\end{array}$ & 38 U.S. 409 & New Orleans & \\
\hline $\begin{array}{l}\text { Allen } v . \\
\text { United States }\end{array}$ & 1840 & C.C.D.Md. & $\begin{array}{l}1 \mathrm{~F} . \text { Cas. } \\
518\end{array}$ & New York & 1794,1800 \\
\hline $\begin{array}{l}\text { The } \\
\text { Catharine }\end{array}$ & 1840 & C.C.S.D.N.Y. & $\begin{array}{l}25 \text { F. Cas. } \\
332\end{array}$ & & \\
\hline $\begin{array}{l}\text { Strohm v. } \\
\text { United States }\end{array}$ & 1840 & $\begin{array}{l}\text { C.C.D.Md. } \\
\text { (on appeal } \\
\text { from D.Md.) }\end{array}$ & $\begin{array}{l}23 \text { F. Cas. } \\
240\end{array}$ & & 1819 \\
\hline $\begin{array}{l}\text { United States } \\
\text { v. Isaac } \\
\text { Morris }\end{array}$ & 1840 & $\begin{array}{l}\text { US Supreme } \\
\text { Court (on } \\
\text { appeal from } \\
\text { C.C.S.D.N.Y.) }\end{array}$ & 39 U.S. 464 & & 1800 \\
\hline The Amistad & 1841 & $\begin{array}{l}\text { US Supreme } \\
\text { Court (on } \\
\text { appeal from } \\
\text { C.C.D.Conn.) }\end{array}$ & 40 U.S. 518 & $\begin{array}{l}\text { Culloden Point, } \\
\text { CT }\end{array}$ & 1800 \\
\hline The Tigris & 1841 & D.Mass. & $\begin{array}{l}23 \text { F.Cas. } \\
1220\end{array}$ & Angola & \\
\hline $\begin{array}{l}\text { United States } \\
\text { v. Flowery }\end{array}$ & 1845 & D.Mass. & $\begin{array}{l}25 \text { F. Cas. } \\
1124\end{array}$ & & 1818 \\
\hline
\end{tabular}




\begin{tabular}{|c|c|c|c|c|c|}
\hline Caption & $\begin{array}{c}\text { Year } \\
\text { Decided }\end{array}$ & Court & Citation & $\begin{array}{l}\text { Location of } \\
\text { Seizure }\end{array}$ & $\begin{array}{c}\text { Act(s) under } \\
\text { which suit } \\
\text { brought }\end{array}$ \\
\hline $\begin{array}{l}\text { United States } \\
\text { v. Libby }\end{array}$ & 1846 & C.C.D.Me. & $\begin{array}{l}26 \text { F. Cas. } \\
928\end{array}$ & & 1820 \\
\hline The Laurens & $\begin{array}{l}1848 \\
1849\end{array}$ & S.D.N.Y. & $\begin{array}{l}14 \text { F. Cas. } \\
1192 \\
\text { (subsequent } \\
\text { case as } \\
1193 \text { ) }\end{array}$ & & 1794,1800 \\
\hline $\begin{array}{l}\text { The Mary } \\
\text { Ann }\end{array}$ & 1848 & S.D.N.Y. & $\begin{array}{l}16 \text { F. Cas. } \\
949\end{array}$ & New York & 1800 \\
\hline $\begin{array}{l}\text { US v. the } \\
\text { Ohio }\end{array}$ & 1849 & E.D.La. & $\begin{array}{l}27 \text { F. Cas. } \\
218\end{array}$ & New Orleans & 1818 \\
\hline $\begin{array}{l}\text { United States } \\
\text { v. Brune }\end{array}$ & 1852 & C.C.E.D.Pa. & $\begin{array}{l}24 \text { F. Cas. } \\
1280\end{array}$ & & 1820 \\
\hline $\begin{array}{l}\text { The } \\
\text { Glamorgan }\end{array}$ & 1854 & D.Mass. & $\begin{array}{l}10 \text { F. Cas. } \\
463\end{array}$ & & $\begin{array}{l}1800,1818, \\
1819,1849\end{array}$ \\
\hline $\begin{array}{l}\text { United States } \\
\text { v. Smith }\end{array}$ & 1855 & C.C.S.D.N.Y. & $\begin{array}{l}27 \mathrm{~F} . \text { Cas. } \\
1138\end{array}$ & & 1820 \\
\hline The Porpoise & 1855 & C.C.D.Mass. & $\begin{array}{l}19 \text { F. Cas. } \\
1064\end{array}$ & & 1800 \\
\hline $\begin{array}{l}\text { United States } \\
\text { v. Darnaud }\end{array}$ & 1855 & C.C.E.D.Pa. & $\begin{array}{l}25 \text { F. Cas. } \\
754\end{array}$ & & 1820 \\
\hline $\begin{array}{l}\text { United States } \\
\text { v. Naylor }\end{array}$ & 1856 & S.D.N.Y. & $\begin{array}{l}27 \text { F. Cas. } \\
78\end{array}$ & & $1794,1808,1818$ \\
\hline The Merchant & 1857 & C.C.S.D.N.Y. & $\begin{array}{l}17 \text { F. Cas. } \\
36\end{array}$ & New York & \\
\hline $\begin{array}{l}\text { Berryman v. } \\
\text { United States }\end{array}$ & 1857 & $\begin{array}{l}\text { Court of } \\
\text { Claims }\end{array}$ & $\begin{array}{l}3 \text { U.S. } \\
\text { Cong. Rep. } \\
\text { C.C. } 47\end{array}$ & New York & 1800,1808 \\
\hline The Orion & 1859 & S.D.N.Y. & $\begin{array}{l}18 \text { F. Cas. } \\
817\end{array}$ & & 1794,1818 \\
\hline $\begin{array}{l}\text { United States } \\
\text { v. Gould }\end{array}$ & 1860 & S.D.Ala. & $\begin{array}{l}25 \text { F. Cas. } \\
1375\end{array}$ & Mobile, AL & 1818 \\
\hline $\begin{array}{l}\text { United States } \\
\text { v. Haun }\end{array}$ & 1860 & C.C.S.D.Ala. & $\begin{array}{l}26 \text { F. Cas. } \\
227\end{array}$ & & 1818 \\
\hline $\begin{array}{l}\text { Ex parte } \\
\text { Gordon }^{\mathrm{f}}\end{array}$ & 1861 & $\begin{array}{l}\text { US Supreme } \\
\text { Court (on } \\
\text { appeal from } \\
\text { C.C.S.D.N.Y.) }\end{array}$ & 66 U.S. 503 & & 1820 \\
\hline $\begin{array}{l}\text { United States } \\
\text { v. the } \\
\text { Augusta }\end{array}$ & 1861 & S.D.N.Y. & $\begin{array}{l}24 \text { F. Cas. } \\
892\end{array}$ & $\begin{array}{l}\text { Greenport, } \\
\text { Long Island, } \\
\text { NY }\end{array}$ & 1794,1818 \\
\hline
\end{tabular}




\begin{tabular}{|c|c|c|c|c|c|}
\hline Caption & $\begin{array}{c}\text { Year } \\
\text { Decided }\end{array}$ & Court & Citation & $\begin{array}{c}\text { Location of } \\
\text { Seizure }\end{array}$ & $\begin{array}{l}\text { Act(s) under } \\
\text { which suit } \\
\text { brought }\end{array}$ \\
\hline $\begin{array}{l}\text { United States } \\
\text { v. Santos }\end{array}$ & 1862 & C.C.S.D.N.Y. & $\begin{array}{l}27 \text { F. Cas. } \\
954\end{array}$ & & \\
\hline $\begin{array}{l}\text { United States } \\
\text { v. Horn }\end{array}$ & 1862 & C.C.S.D.N.Y. & $\begin{array}{l}26 \text { F. Cas. } \\
373\end{array}$ & & \\
\hline $\begin{array}{l}\text { United States } \\
\text { v. Kelly }\end{array}$ & 1863 & D.Mass. & $\begin{array}{l}26 \text { F. Cas. } \\
697\end{array}$ & $\begin{array}{l}\text { New Bedford, } \\
\text { MA }\end{array}$ & 1818 \\
\hline $\begin{array}{l}\text { United States } \\
\text { v. the Isla de } \\
\text { Cuba }\end{array}$ & 1865 & C.C.D.Mass. & $\begin{array}{l}26 \mathrm{~F} . \text { Cas. } \\
551\end{array}$ & Boston & 1818 \\
\hline $\begin{array}{l}\text { The Slavers } \\
\text { (The Kate, } \\
\text { the Reindeer, } \\
\text { the Sarah, the } \\
\text { Weathergage) }\end{array}$ & 1864 & $\begin{array}{l}\text { US Supreme } \\
\text { Court (on } \\
\text { appeal from } \\
\text { S.D.N.Y.) }\end{array}$ & $\begin{array}{l}69 \text { U.S. } \\
350,366, \\
375,383\end{array}$ & & 1794,1818 \\
\hline \multicolumn{6}{|c|}{$\begin{array}{l}\text { Notes: } \\
\text { a Previous case before the Supreme Court was reported as } 18 \text { U.S. } 338 \text { (1820). } \\
\text { b This case involves the seizure of the Josefa Segunda, the same matter settled by the Supreme Court in } 1825 . \\
{ }^{\mathrm{c}} \text { Despite the spelling discrepancy, this matter deals with the same Isabelita adjudicated in Governor of Georgia v. } \\
\text { Madrazo (1828). } \\
{ }^{\mathrm{d}} \text { This is the fourth dispute settled by the Supreme Court in the seizure of the Josefa Segunda twenty years prior. } \\
{ }^{\mathrm{e}} \text { This case involves the seizure of the Catharine, the ship over which Chief Justice Taney ruled in Allen v. US in } \\
\text { the Circuit Court for the District of Maryland that same year. } \\
\text { f Gordon was found guilty of piracy under the } 1820 \text { act in US v. Gordon, } 25 \text { F. Cas. } 1364 \text { (C.C.S.D.N.Y. 1861). } \\
\text { g This is the third case involving the Isla de Cuba, the first being in } 1860 \text { (26 F. Cas. 553) and the second in } 1864 \\
\text { (26 F. Cas. 548). }\end{array}$} \\
\hline
\end{tabular}




\section{APPENDIX B: US NAVAL SEIZURES}

Table B-1. Ships seized by US Navy Africa Squadron following Webster-Ashburton Treaty

\begin{tabular}{|c|c|c|c|c|}
\hline No. & Vessel & Captor & Date of Seizure & Location of Seizure \\
\hline 1 & Uncas & Porpoise & March 1, 1844 & Gallinas River \\
\hline 2 & Spitfire & Truxtun & March 24, 1845 & Pongas River \\
\hline 3 & Patuxent & Yorktown & September 27, 1845 & Cape Mount \\
\hline 4 & Pons & Yorktown & September 30,1845 & Kabenda \\
\hline 5 & Merchant & Jamestown & December 3, 1845 & Sierra Leone \\
\hline 6 & Panther & Yorktown & December 15,1845 & Kabenda \\
\hline 7 & Robert Wilson & Jamestown & January 15,1846 & Porto Prava \\
\hline 8 & Malaga & Boxer & April 13, 1846 & Kabenda \\
\hline 9 & Casket & Marion & August 2, 1846 & Kabenda \\
\hline 10 & Chancellor & Dolphin & April 10, 1847 & Cape Palmas \\
\hline 11 & Excellent & John Adams & April 23, 1850 & Ambriz \\
\hline 12 & Martha & Perry & June 6,1850 & Ambriz \\
\hline 13 & Chatsworth & Perry & September 11,1850 & Ambriz \\
\hline 14 & Advance & Germantown & November 3, 1852 & Porto Prava \\
\hline 15 & R. P. Brown & Germantown & January 23,1853 & Porto Prava \\
\hline 16 & H. N. Gambrill & Constitution & November 3, 1853 & Kongo River \\
\hline 17 & Glamorgan & Perry & March 10, 1854 & Kongo River \\
\hline 18 & W. G. Lewis & Dale & November 6, 1857 & Kongo River \\
\hline 19 & Brothers & Marion & September 8, 1858 & Mayumba \\
\hline 20 & Julia Dean & Vincennes & December 28,1858 & Cape Coastal Castle \\
\hline 21 & Orion & Marion & April 21, 1859 & Kongo River \\
\hline 22 & Ardennes & Marion & April 27, 1859 & Kongo River \\
\hline 23 & Emily & Portsmouth & September 21,1859 & Loango River \\
\hline 24 & Delicia & Constellation & September 21,1859 & Kabenda \\
\hline 25 & Virginian & Portsmouth & February 6, 1860 & Kongo River \\
\hline 26 & Falmouth & Portsmouth & May 6,1860 & Porto Prava \\
\hline 27 & Thomas Achorn & Mystic & June 29,1860 & Kabenda \\
\hline 28 & Triton & Mystic & July 16,1860 & Loango River \\
\hline 29 & Erie & Mohican & August 8,1860 & Kongo River \\
\hline 30 & Storm King & San Jacinto & August 8,1860 & Kongo River \\
\hline 31 & Cora & Constellation & September 26,1860 & Kongo River \\
\hline 32 & Bonito & San Jacinto & October 10,1860 & Kongo River \\
\hline 33 & Express & Saratoga & February 25, 1861 & Possibly Loango \\
\hline 34 & Nightingale & Saratoga & April 21, 1861 & Kabenda \\
\hline 35 & Triton & Constellation & May 20, 1861 & Kongo River \\
\hline 36 & Falmouth & Sumpter & June 14,1861 & Kongo River \\
\hline
\end{tabular}

Source: Canney, Africa Squadron, 233-234. 


\section{APPENDIX C: US NAVAL COMMITMENT TO SLAVE-TRADE SUPPRESSION}

\section{US Naval Commitment by Number of Ships, 1825-1860}

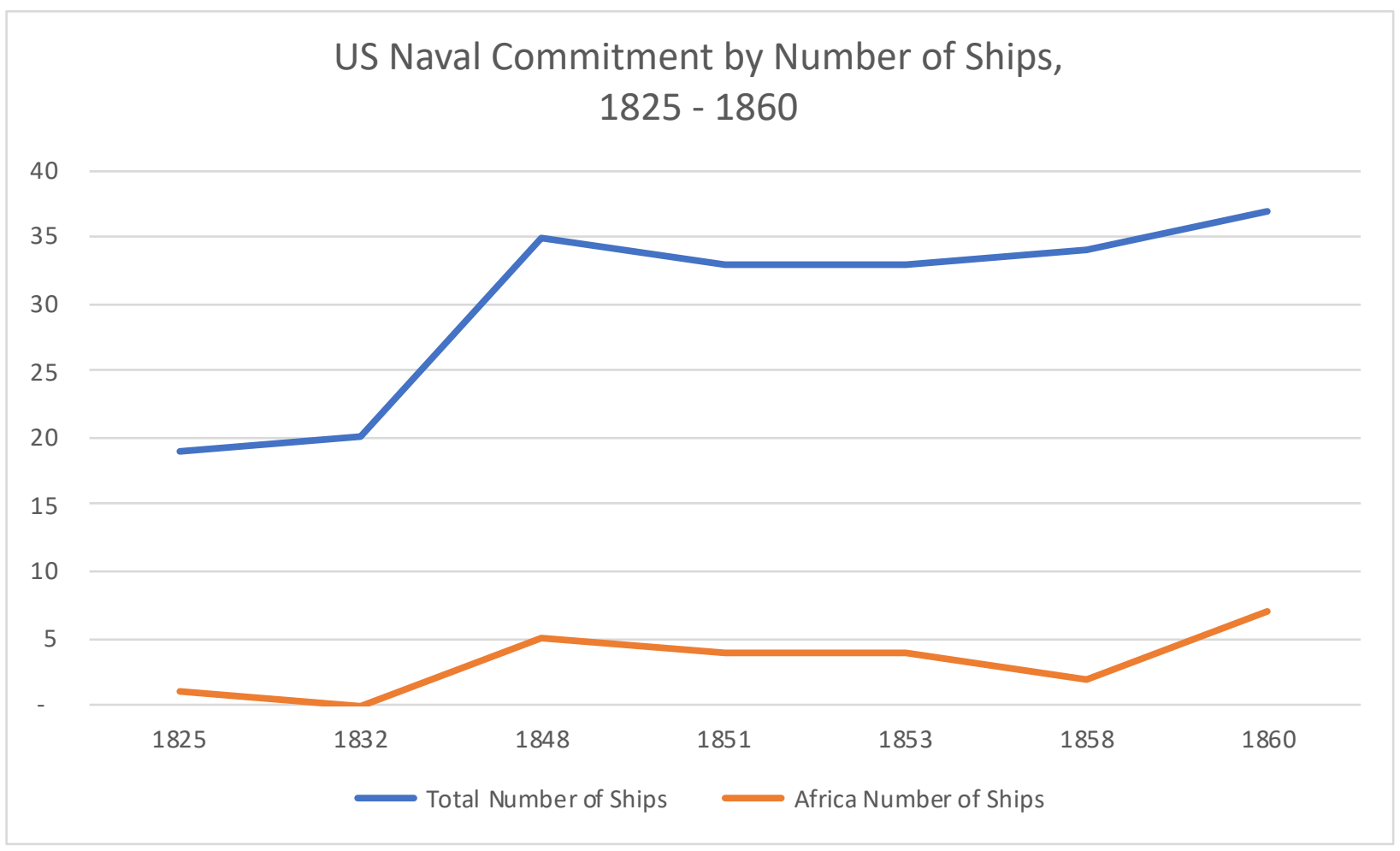

Table C-1. Africa Squadron number of ships relative to entire US Navy

\begin{tabular}{cccc}
\hline & Total Number of Ships & Africa Number of Ships & Percentages \\
\hline 1825 & 19 & 1 & $5.3 \%$ \\
1832 & 20 & - & $0.0 \%$ \\
1848 & 35 & 5 & $14.3 \%$ \\
1851 & 33 & 4 & $12.1 \%$ \\
1853 & 33 & 4 & $12.1 \%$ \\
1858 & 34 & 2 & $5.9 \%$ \\
1860 & 37 & 7 & $18.9 \%$
\end{tabular}

Sources: These figures are based on the digitally transcribed versions of: Register of the Commissioned Officers and Warrant Officers of the Navy of the United States, Including Officers of the Marine Corps, \&c., for the Year 1825 (Washington, DC, 1848); Register of the Commissioned and Warrant Officers of the Navy of the United States, Including Officers of the Marine Corps, and Others, for the Year 1848 (Washington, DC, 1848); Register of the Commissioned and Warrant Officers of the Navy of the United States, Including Officers of the Marine Corps, and

Others, for the Year 1852 (Washington, DC, 1852); Register of the Commissioned and Warrant Officers of the Navy of the United States, Including Officers of the Marine Corps, and Others, for the Year 1854 (Washington, DC, 1853); Register of the Commissioned and Warrant Officers of the Navy of the United States, Including Officers of the Marine Corps, and Others, for the Year 1859 (Washington, DC, 1859); Register of the Commissioned and Warrant Officers of the Navy of the United States, Including Officers of the Marine Corps, and Others, for the Year 1861 (Washington, DC, 1861). Each is found on https://www.bluejacket.com/index_site.html. 
US Naval Commitment by Guns, 1825-1860

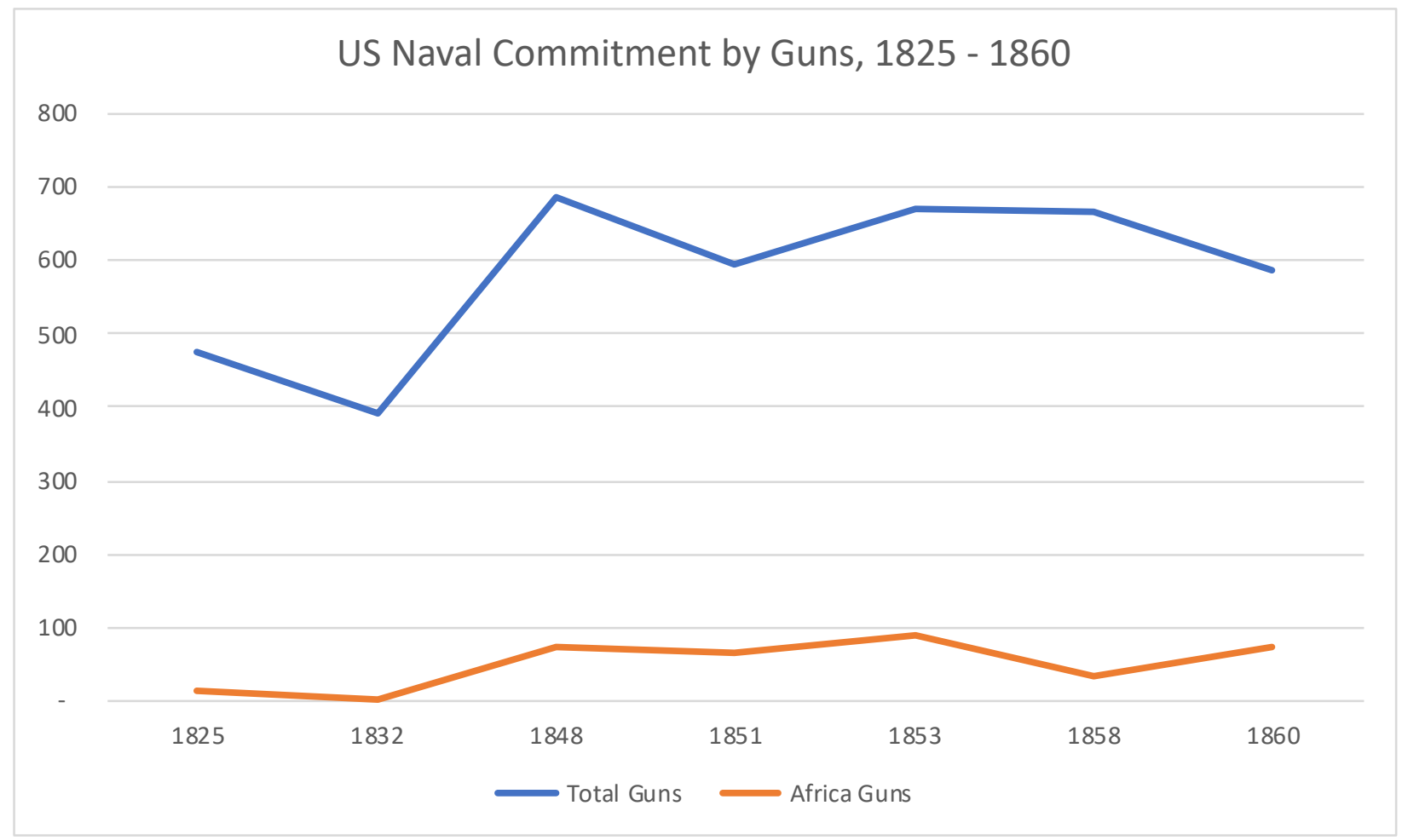

Table C-2. Africa Squadron Guns relative to entire US Navy

\begin{tabular}{cccc}
\hline & Total Guns & Africa Guns & Percentages \\
\hline 1825 & 476 & 12 & $2.5 \%$ \\
1832 & 390 & - & $0.0 \%$ \\
1848 & 685 & 72 & $10.5 \%$ \\
1851 & 595 & 66 & $11.1 \%$ \\
1853 & 669 & 88 & $13.2 \%$ \\
1858 & 667 & 32 & $4.8 \%$ \\
1860 & 588 & 73 & $12.4 \%$
\end{tabular}

Sources: For source attribution, see note to Table C-1. 
US Naval Commitment by Tonnage, 1825-1860

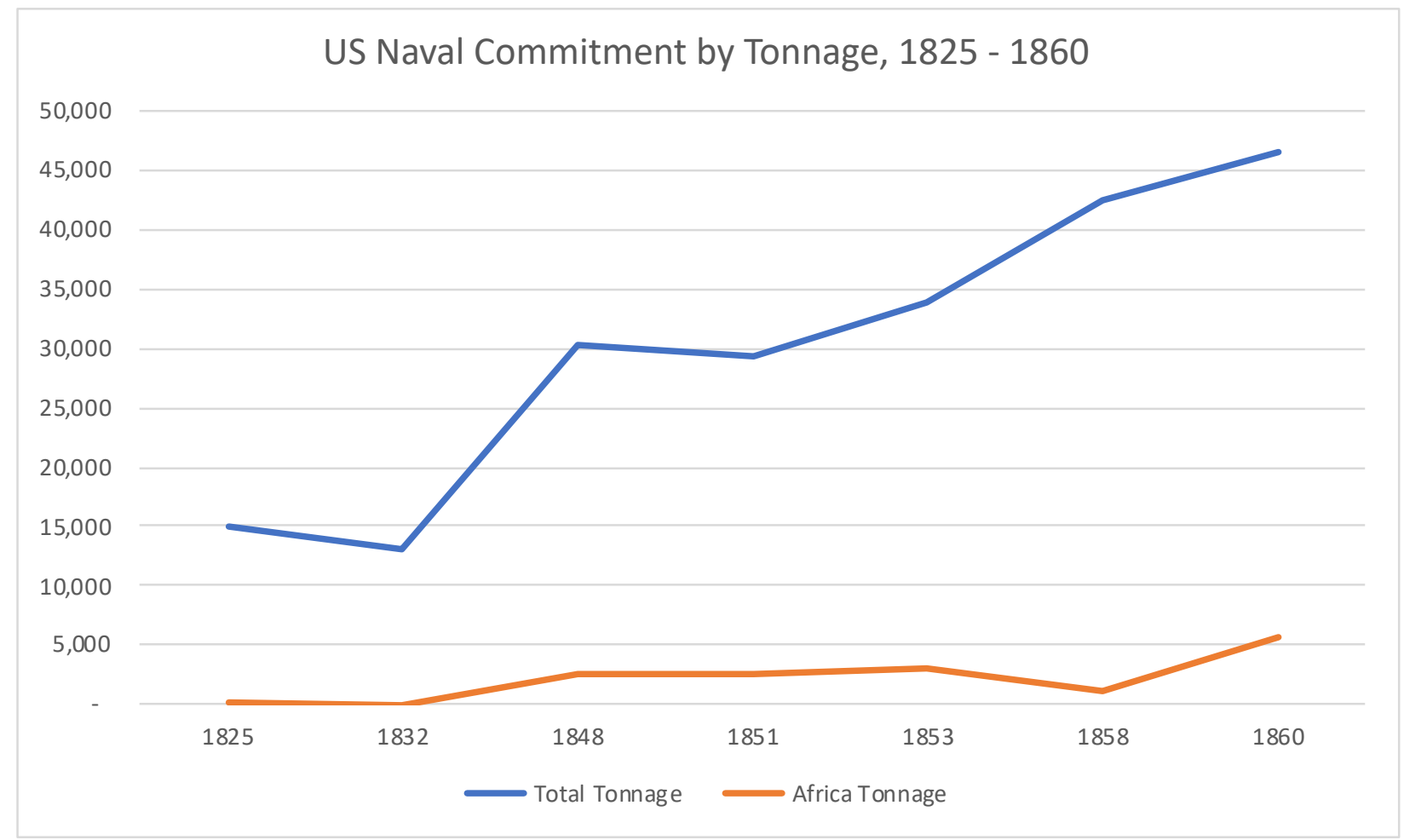

Table C-3. Africa Squadron tonnage relative to entire US Navy

\begin{tabular}{cccc}
\hline & Total Tonnage & Africa Tonnage & \\
\hline 1825 & 15,097 & 177 & $1.2 \%$ \\
1832 & 13,193 & - & $0.0 \%$ \\
1848 & 30,207 & 2,637 & $8.7 \%$ \\
1851 & 29,232 & 2,464 & $8.4 \%$ \\
1853 & 33,910 & 3,019 & $8.9 \%$ \\
1858 & 42,542 & 1,132 & $2.7 \%$ \\
1860 & 46,591 & 5,740 & $12.3 \%$
\end{tabular}

Sources: For source attribution, see note to Table C-1. 


\section{Sample Data Table (1848)}

\begin{tabular}{|c|c|c|c|c|c|}
\hline Class & Name & Rate & Tons & Situation & Location \\
\hline Ships of the Line & Pennsylvania & 120 & 3,241 & $\begin{array}{l}\text { In } \\
\text { commission } \\
\text { In }\end{array}$ & $\begin{array}{l}\text { Receiving Ship, } \\
\text { Norfolk, VA } \\
\text { Receiving Shin }\end{array}$ \\
\hline Ships of the Line & Franklin & 74 & 3,680 & commission & Boston \\
\hline Ships of the Line & Columbus & 74 & 2,480 & $\begin{array}{l}\text { In ordinary }{ }^{b} \\
\text { In }\end{array}$ & Norfolk, VA \\
\hline Ships of the Line & $\begin{array}{l}\text { Ohio } \\
\text { North }\end{array}$ & 74 & 2,757 & $\begin{array}{l}\text { commission } \\
\text { In }\end{array}$ & $\begin{array}{l}\text { Pacific } \\
\text { Receiving ship, New }\end{array}$ \\
\hline Ships of the Line & Carolina & 74 & 2,633 & commission & York \\
\hline Ships of the Line & Delaware & 74 & 2,633 & $\begin{array}{l}\text { In ordinary } \\
\text { On the }\end{array}$ & Norfolk, VA \\
\hline Ships of the Line & Alabama & 74 & 2,633 & stocks $^{\mathrm{c}}$ & Portsmouth, NH \\
\hline Ships of the Line & Vermont & 74 & 2,633 & $\begin{array}{l}\text { In ordinary } \\
\text { On the }\end{array}$ & Boston \\
\hline Ships of the Line & Virginia & 74 & 2,633 & stocks & Boston \\
\hline Ships of the Line & New York & 74 & 2,633 & stocks & Norfolk, VA \\
\hline Ships of the Line & New Orleans & 74 & 2,805 & $\begin{array}{l}\text { On the } \\
\text { stocks } \\
\text { In }\end{array}$ & Sackett's Harbor, NY \\
\hline Ships of the Line & Independence & 74 & 2,257 & Commission & Pacific \\
\hline Frigates, 1st Class & United States & 44 & 1,607 & $\begin{array}{l}\text { In ordinary } \\
\text { In }\end{array}$ & Norfolk, VA \\
\hline Frigates, 1st Class & Constitution & 44 & 1,607 & commission & Mediterranean \\
\hline Frigates, 1st Class & Potomac & 44 & 1,726 & $\begin{array}{l}\text { In ordinary } \\
\text { In }\end{array}$ & Norfolk, VA \\
\hline Frigates, 1st Class & Brandywine & 44 & 1,726 & commission & Coast of Brazil \\
\hline Frigates, 1st Class & Columbia & 44 & 1,726 & In ordinary & Norfolk, VA \\
\hline Frigates, 1st Class & Congress & 44 & 1,867 & In ordinary & Norfolk, VA \\
\hline Frigates, 1st Class & Cumberland & 44 & 1,726 & $\begin{array}{l}\text { In ordinary } \\
\text { In }\end{array}$ & New York \\
\hline Frigates, 1st Class & Savannah & 44 & 1,726 & $\begin{array}{l}\text { commission } \\
\text { In }\end{array}$ & Pacific \\
\hline Frigates, 1st Class & Raritan & 44 & 1,726 & commission & Home Squadron \\
\hline
\end{tabular}




\begin{tabular}{|c|c|c|c|c|c|}
\hline Class & Name & Rate & Tons & Situation & Location \\
\hline Frigates, 1st Class & Santee & 44 & 1,726 & $\begin{array}{l}\text { On the } \\
\text { Stocks } \\
\text { On the }\end{array}$ & Portsmouth, $\mathrm{NH}$ \\
\hline Frigates, 1st Class & Sabine & 44 & 1,726 & $\begin{array}{l}\text { Stocks } \\
\text { In }\end{array}$ & New York \\
\hline Frigates, 1st Class & St. Lawrence & 44 & 1,726 & commission & European Seas \\
\hline Frigates, 2d Class & Constellation & 36 & 1,452 & In ordinary & Norfolk, VA \\
\hline Frigates, 2d Class & Macedonian & 36 & 1,341 & $\begin{array}{l}\text { In ordinary } \\
\text { In }\end{array}$ & New York \\
\hline Sloops & Saratoga & 20 & 882 & commission & Home Squadron \\
\hline Sloops & John Adams & 20 & 700 & In ordinary & Boston \\
\hline Sloops & Vincennes & 20 & 700 & $\begin{array}{l}\text { In ordinary } \\
\text { In }\end{array}$ & New York \\
\hline Sloops & Warren & 20 & 691 & commission & Pacific \\
\hline Sloops & Falmouth & 20 & 703 & In ordinary & Boston \\
\hline Sloops & Fairfield & 20 & 700 & In ordinary & Norfolk, VA \\
\hline Sloops & Vandalia & 20 & 783 & $\begin{array}{l}\text { In ordinary } \\
\text { In }\end{array}$ & Norfolk, VA \\
\hline Sloops & St. Louis & 20 & 700 & commission & Coast of Brazil \\
\hline Sloops & Cyane & 20 & 792 & In ordinary & Norfolk, VA \\
\hline Sloops & Levant & 20 & 792 & $\begin{array}{l}\text { In ordinary } \\
\text { In }\end{array}$ & Norfolk, VA \\
\hline Sloops & Portsmouth & 20 & 1,022 & $\begin{array}{l}\text { commission } \\
\text { In }\end{array}$ & Coast of Africa \\
\hline Sloops & Plymouth & 20 & 989 & $\begin{array}{l}\text { commission } \\
\text { In }\end{array}$ & East Indies \\
\hline Sloops & St. Mary's & 20 & 958 & $\begin{array}{l}\text { commission } \\
\text { In }\end{array}$ & Pacific \\
\hline Sloops & Jamestown & 20 & 985 & $\begin{array}{l}\text { commission } \\
\text { In }\end{array}$ & Mediterranean \\
\hline Sloops & Albany & 20 & 1,042 & $\begin{array}{l}\text { commission } \\
\text { In }\end{array}$ & Home Squadron \\
\hline Sloops & Germantown & 20 & 939 & $\begin{array}{l}\text { commission } \\
\text { In }\end{array}$ & $\begin{array}{l}\text { Home Squadron } \\
\text { Receiving Ship, }\end{array}$ \\
\hline Sloops & Ontario & 18 & 509 & commission & Baltimore \\
\hline
\end{tabular}




\begin{tabular}{|c|c|c|c|c|c|}
\hline Class & Name & Rate & Tons & Situation & Location \\
\hline Sloops & Decatur & 16 & 566 & $\begin{array}{l}\text { In } \\
\text { commission } \\
\text { In }\end{array}$ & Coast of Africa \\
\hline Sloops & Preble & 16 & 566 & $\begin{array}{l}\text { commission } \\
\text { In }\end{array}$ & Pacific \\
\hline Sloops & Yorktown & 16 & 566 & commission & Coast of Africa \\
\hline Sloops & Marion & 16 & 566 & $\begin{array}{l}\text { In ordinary } \\
\text { In }\end{array}$ & Boston \\
\hline Sloops & Dale & 16 & 566 & commission & Pacific \\
\hline Brigs & Boxer & 10 & 194 & $\begin{array}{l}\text { In ordinary } \\
\text { In }\end{array}$ & Philadelphia \\
\hline Brigs & Dolphin & 10 & 224 & $\begin{array}{l}\text { commission } \\
\text { In }\end{array}$ & East Indies \\
\hline Brigs & Porpoise & 10 & 224 & $\begin{array}{l}\text { commission } \\
\text { In }\end{array}$ & Coast of Africa \\
\hline Brigs & Bainbridge & 10 & 259 & $\begin{array}{l}\text { commission } \\
\text { In }\end{array}$ & Coast of Africa \\
\hline Brigs & Perry & 10 & 280 & $\begin{array}{l}\text { commission } \\
\text { In }\end{array}$ & Coast of Brazil \\
\hline Schooners & Flirt & 2 & 150 & $\begin{array}{l}\text { commission } \\
\text { In }\end{array}$ & Home Squadron \\
\hline Schooners & Wave & 1 & - & $\begin{array}{l}\text { commission } \\
\text { In }\end{array}$ & Coast Survey \\
\hline Schooners & Phoenix & 2 & 90 & $\begin{array}{l}\text { commission } \\
\text { In }\end{array}$ & Coast Survey \\
\hline Schooners & Petrel & 1 & 90 & $\begin{array}{l}\text { commission } \\
\text { In }\end{array}$ & Coast Survey \\
\hline Schooners & Taney & 1 & 112 & $\begin{array}{l}\text { commission } \\
\text { In }\end{array}$ & Mediterranean \\
\hline Steamers & Mississippi & 10 & 1,692 & $\begin{array}{l}\text { commission } \\
\text { On the }\end{array}$ & Home Squadron \\
\hline Steamers & Susquehanna & - & 2,450 & $\begin{array}{l}\text { stocks } \\
\text { On the }\end{array}$ & Philadelphia \\
\hline Steamers & Powhatan & - & 2,415 & stocks & Norfolk \\
\hline Steamers & Saranac & - & 1,446 & $\begin{array}{l}\text { In ordinary } \\
\text { On the }\end{array}$ & Portsmouth, NH \\
\hline Steamers & San Jacinto & - & 1,446 & stocks & New York \\
\hline Steamers & Fulton & 4 & 698 & $\begin{array}{l}\text { In ordinary } \\
\text { In }\end{array}$ & $\begin{array}{l}\text { New York } \\
\text { Receiving Ship, }\end{array}$ \\
\hline Steamers & Union & 4 & 956 & commission & Philadelphia \\
\hline
\end{tabular}




\begin{tabular}{llccll}
\multicolumn{1}{c}{ Class } & \multicolumn{1}{c}{ Name } & Rate & Tons & \multicolumn{1}{c}{ Situation } & \multicolumn{1}{c}{ Location } \\
\hline Steamers & Princeton & 9 & 900 & $\begin{array}{l}\text { In } \\
\text { commission }\end{array}$ & Mediterranean \\
Steamers & Michigan & 1 & 582 & $\begin{array}{l}\text { In } \\
\text { commission }\end{array}$ & Great Lakes \\
Steamers & Alleghany & 2 & 989 & $\begin{array}{l}\text { In } \\
\text { commission }\end{array}$ & Mediterranean \\
Steamers & Vixen & 3 & 240 & $\begin{array}{l}\text { commission } \\
\text { In }\end{array}$ & Home Squadron \\
Steamers & $\begin{array}{l}\text { Water Witch } \\
\text { General }\end{array}$ & 1 & 378 & commission & Home Squadron \\
Steamers & Taylor & - & 152 & Tender & Pensacola, FL \\
Steamers & Engineer & - & - & $\begin{array}{l}\text { Tender } \\
\text { In }\end{array}$ & Norfolk, VA \\
Store Ships and Brigs & Relief & 6 & 468 & $\begin{array}{l}\text { commission } \\
\text { In }\end{array}$ & Coast of Brazil \\
Store Ships and Brigs & Erie & 4 & 509 & $\begin{array}{l}\text { commission } \\
\text { In }\end{array}$ & Mediterranean \\
Store Ships and Brigs & Lexington & 6 & 691 & $\begin{array}{l}\text { commission } \\
\text { In }\end{array}$ & Pacific \\
Store Ships and Brigs & Southampton & 4 & 567 & $\begin{array}{l}\text { commission } \\
\text { In }\end{array}$ & Pacific \\
Store Ships and Brigs & Supply & 4 & 547 & $\begin{array}{l}\text { commission } \\
\text { In }\end{array}$ & Mediterranean \\
Store Ships and Brigs & Fredonia & 4 & 800 & $\begin{array}{l}\text { commission } \\
\text { Pacific }\end{array}$ &
\end{tabular}

Totals:

Ships, Guns, Tons

Source: For source attribution, see Table C-1 for 1848 US Navy Register.

a Ships listed "in commission" were, as King, Hattendorf, and Estes defined, in active service. Dean King, John B. Hattendorf, and J. Worth Estes, A Sea of Words: A Lexicon and Companion for Patrick O'Brian's Seafaring Tales (New York: Henry Holt, 1995), s.v. "commission."

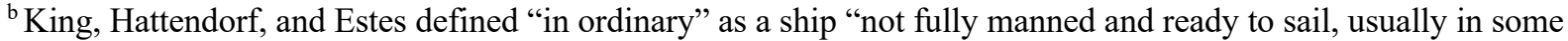
form of storage or disrepair in a harbor or dockyard." For this reason, ships listed "in ordinary" were not excluded from "in commission" totals. King, Hattendorf, and Estes, A Sea of Words, s.v. "in ordinary."

"According to King, Hattendorf, and Estes, ships "on the stocks" are under construction. King, Hattendorf, and Estes, A Sea of Words, s.v. "stocks." 
Table C-5. Summary data table of 1848 US Navy Register

\begin{tabular}{|c|c|c|c|c|c|c|}
\hline $\begin{array}{c}\text { Summary by } \\
\text { Situation }\end{array}$ & $\begin{array}{c}\text { Qty } \\
\text { of } \\
\text { Ships } \\
\end{array}$ & Guns & Tons & $\begin{array}{l}\quad \text { Perce } \\
\text { Qty of } \\
\text { Ships } \\
\end{array}$ & ages to $\mathrm{T}$ & Tons \\
\hline In Commission & 46 & 1,003 & 44,808 & $60.5 \%$ & $48.4 \%$ & $48.4 \%$ \\
\hline In Ordinary & 21 & 684 & 27,265 & $27.6 \%$ & $33.0 \%$ & $29.5 \%$ \\
\hline On the Stocks & 9 & 384 & 20,467 & $11.8 \%$ & $18.5 \%$ & $22.1 \%$ \\
\hline In Service & - & - & - & $0.0 \%$ & $0.0 \%$ & $0.0 \%$ \\
\hline Preparing for Sea & - & - & - & $0.0 \%$ & $0.0 \%$ & $0.0 \%$ \\
\hline At Hoboken & - & - & - & $0.0 \%$ & $0.0 \%$ & $0.0 \%$ \\
\hline Totals & 76 & 2,071 & 92,540 & $100.0 \%$ & $100.0 \%$ & $100.0 \%$ \\
\hline
\end{tabular}

Table C-6. Recapitulation of adjustments

Total Ships “In Commission” from Summary Above $\quad 46 \quad 1,003 \quad 44,808$

Adjustments to Ships "In Commission"

Less Ships that are "Receiving Ships"

(5) (290)

$(11,019)$

Less Ships that are "Store Vessels"

(6) (28)

$(3,582)$

Less Ships that are "Permanent Store \& Receiving Vessels"

Total Adjustments

(11) (318)

$(14,601)$

Adjusted Total Ships "In Commission"

$35 \quad 685$

30,207

\begin{tabular}{lrrr} 
Coast of Africa total & 5 & 72 & 2,637 \\
\hline As a Percentage of In Commission Vessels (adjusted) & $14.29 \%$ & $\mathbf{1 0 . 5 1 \%}$ & $\mathbf{8 . 7 3 \%}$ \\
\hline
\end{tabular}




\section{APPENDIX D: ROYAL NAVY COMMITMENT TO SLAVE-TRADE \\ SUPPRESSION (1837)}

Table D-1. Total Royal Navy Ships 1837

\begin{tabular}{lrrr|rr}
\hline \multicolumn{1}{c}{ Summary by } & & & \multicolumn{2}{c}{$\begin{array}{c}\text { Percentages to } \\
\text { Totals }\end{array}$} \\
\hline \multicolumn{1}{c}{$\begin{array}{c}\text { Qty of } \\
\text { Ships }\end{array}$} & Guns & Tons & Guns & Tons \\
In Commission & 138 & 3,730 & 104,725 & $30.0 \%$ & $32.7 \%$ \\
In Ordinary & 133 & 7,718 & 192,439 & $62.1 \%$ & $60.2 \%$ \\
Harbor Service & 3 & 344 & 7,681 & $2.8 \%$ & $2.4 \%$ \\
Gunnery training & 2 & 216 & 4,594 & $1.7 \%$ & $1.4 \%$ \\
Depot & 6 & 376 & 9,374 & $3.0 \%$ & $2.9 \%$ \\
Tender & 1 & 46 & 1,088 & $0.4 \%$ & $0.3 \%$ \\
\hline Totals & $\mathbf{2 8 3}$ & $\mathbf{1 2 , 4 3 0}$ & $\mathbf{3 1 9 , 9 0 1}$ & $\mathbf{1 0 0 . 0 \%}$ & $\mathbf{1 0 0 . 0 \%}$ \\
\hline
\end{tabular}

Table D-2. Royal Navy ships assigned to the Cape of Good Hope and Coast of Africa 1837

Class Name Guns Tons

$\begin{array}{llcr}\text { Ships of the Line } & \text { Melville } & 74 & 1,767 \\ \text { Frigates(flagship) } & \text { Thalia } & 46 & 1,083 \\ \text { Sloops and Brigs } & \text { Childers } & 18 & 385 \\ \text { Sloops and Brigs } & \text { Pylades } & 18 & 433 \\ \text { Sloops and Brigs } & \text { Scout } & 18 & 488 \\ \text { Sloops and Brigs } & \text { Bonetta } & 8 & 236 \\ \text { Sloops and Brigs } & \text { Brisk } & 10 & 233 \\ \text { Sloops and Brigs } & \text { Buzzard } & 10 & 232 \\ \text { Sloops and Brigs } & \text { Charybdis* } & 10 & \end{array}$




\begin{tabular}{|c|c|c|c|}
\hline Class & Name & Guns & Tons \\
\hline Sloops and Brigs & Columbine* & 18 & 492 \\
\hline Sloops and Brigs & Curlew & 10 & 233 \\
\hline Sloops and Brigs & Dolphin & 3 & 319 \\
\hline Sloops and Brigs & Forester & 10 & 230 \\
\hline Sloops and Brigs & $\operatorname{Lyn} x$ & 10 & 232 \\
\hline Sloops and Brigs & Partridge* & 10 & 230 \\
\hline Sloops and Brigs & Pelican & 18 & 385 \\
\hline Sloops and Brigs & Saracen & 10 & 227 \\
\hline Sloops and Brigs & Waterwitch & 10 & 323 \\
\hline Totals: Ships, Guns, Tons & 18 & 311 & $\mathbf{7 , 8 4 7}$ \\
\hline \% to "In Commission" ships & $13.0 \%$ & $8.0 \%$ & $7.0 \%$ \\
\hline
\end{tabular}

Source: "Royal Navy Strength on Victoria's Ascension to the Throne, 1837," http://naval-history.net/xGWRNOrganisation 1837.htm. Ships were confirmed to have been assigned to the Cape of Good Hope and Coast of Africa Squadron through: The Navy List, Corrected to the 20th Dec., 1837 (London, 1838), 59-82, https://hdl.handle.net/2027/mdp.39015025976740; Rif Winfield, British Warships in the Age of Sail, 18171863: Design, Construction, Careers, and Fates (Barnsley, UK: Seaforth, 2014).

Notes:

* Charybdis, Columbine, and Partridge were in transit to their duty stations in December 1837. 